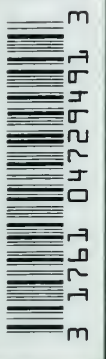

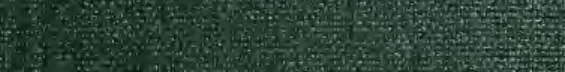
(c)

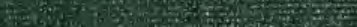

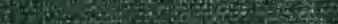

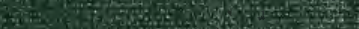

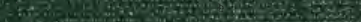

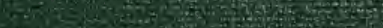

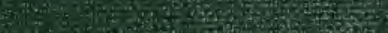
I.

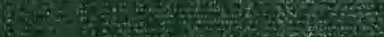
A.

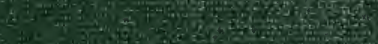

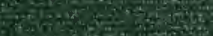

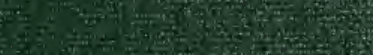

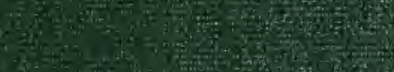

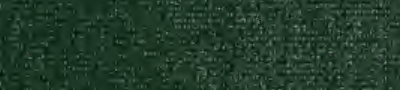

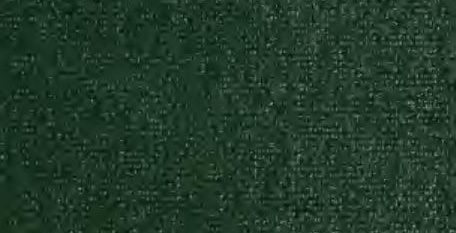

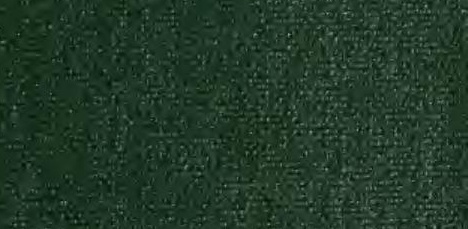

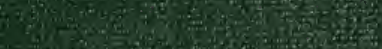
wis

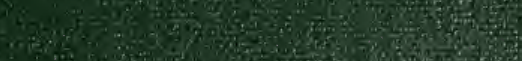

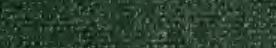

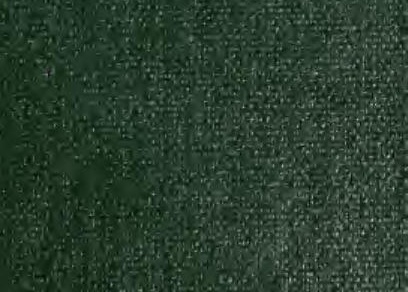

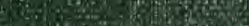


Digitized by the Internet Archive in 2008 with funding from Microsoft Corporation 




\section{THE LIFE AND LOVE OF THE INSECT}




\section{AGENTS}

AMERICA * , , THE MACMILLAN COMPANY

64 \& 66 FIFTH AVENUE, NEW YORK

AU BTRALABLA OXFORD UNIVERSITY PRESS

205 FI INDERS LANE, MELBOURNE

CANADA THE MACMLLLAN COMPANY OF CANADA, LTD. ST. MARTIN'S HOUSB, 70 BOND STREET, TORONTO

INDLA ..... MACMILLAN \& COMPANY, LTD.

maCMILLAN BUILDTNG, BOMBAY

sog BOW BAZAAR STREeT, CALCUTTA 



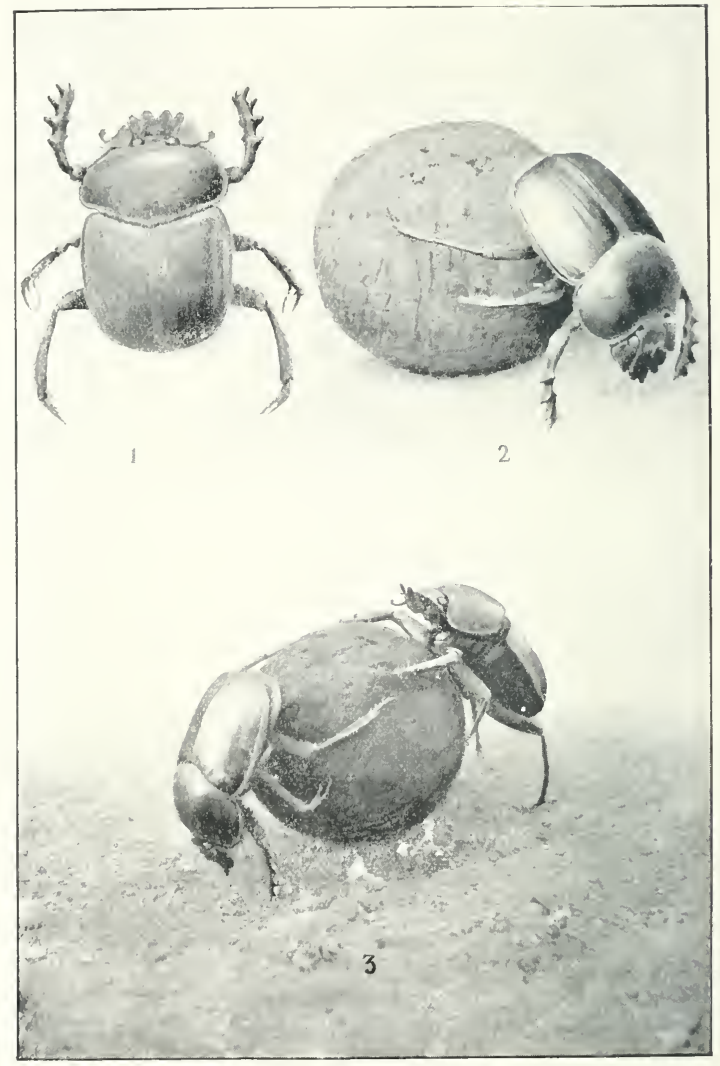

1. The Sacred Beetle.

2. The Sacred Beetle rolling his pill. 3. Rolling the pill to the eating burrow. 


\title{
THE
}

\section{LIFE A ND LOVE \\ OF THE INSECT}

\author{
BY \\ J. HENRI FABRE
}

TRANSLATED BY

ALEXANDER TEIXEIRA DE MATTOS

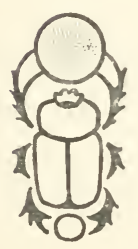

LONDON

ADAM AND CHARLES BLACK

1914 
First published September, IQII

Reprinted Janwary, 1914

$\frac{\sin 4254}{17.3 .55}$

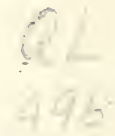

$733 / 3$ 


\section{TRANSLATOR'S NOTE}

THE author of these essays was born at Sérignan, in Provence, in the year 1823, and was long in coming to his own. His birthday, indeed, is now celebrated annually (Henri Fabre is still alive) at both Sérignan and Orange ; but, as Maurice Maeterlinck, writing of this "Insect's Homer ... whose brow should be girt with a double and radiant crown," says :

"Fame is often forgetful, negligent, behindhand or unjust; and the crowd is almost ignorant of the name of J. H. Fabre, who is one of the most profound and inventive scholars and also one of the purest writers and, I was going to add, one of the finest poets of the century that is just past."

Fabre's Souvenirs-Entomologigues form ten volumes, containing two to three hundred essays in all. The present book is a translation of the greater part of a volume of selected essays, comprising, in addition to those here presented, three that appeared in a volume entitled Insect Life and published ten years ago by Messrs. Macmillan, in a version from the able pen of 
the author of Mademoiselle Mori. This volume contained also the first of the four articles descriptive of the habits of the Sacred Beetle; and the publishers desire me to express their thanks to Messrs. Macmillan for permission to include in The Life and Love of the Insect a variant of that first chapter from Insect Life. The omission of three essays included in the French volume of selections explains the absence of reference to certain insects represented in some of the photographic plates.

I should like to mention my personal sense of gratitude to a gentleman belonging to a class of workers whose services are not always recognized in the manner which they deserve. I speak of Mr. Marmaduke Langdale, my untiring, eager and accurate "searcher," whose work at both branches of the British Museum-to say nothing of his uncommonly thorough acquaintance with the French language-has greatly assisted me in my task of translation and saved me, I suspect, from making more than one blunder.

ALEXANDER TEIXEIRA DE MATTOS.

Chelsea, 11 July, 1911. 


\section{CONTENTS}

TRANSIATOR'S NOTE CIFAPTER

I. THE SACRED BEETLE - $\quad$ - $\quad$ - $\quad$ - $\quad$ - 1

II. THE SACRED BTETLE : THE PEAR - - - $\quad$ - $1 S$

U. THE SACRED BEETLE : THE MODELLIXG - - - 32

IV. THE SACRED BEETLE: THE GRUB, THE METAMORPHOSIS.

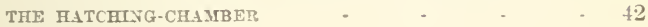

V. THE SPAXISH COPRIS

rI. THE ONTHOPHAGI

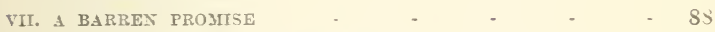

VIII. A DUNG-BEETLE OF THE PAMPAS - $\quad$ - $\quad$ - 99

IX. THE GEOTRUPES : THE PUBLIC HEALTH - - 113

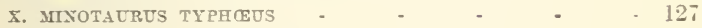

XI. THE TWO-BANDED SCOLIA $\quad$ - $\quad$ - $\quad$ - 143

XII. THE RISGED CALICURGES -.

XIII. THE OLD WEEVILS - $\quad$ - $\quad$ - $\quad$ - 171

XIV. LEAF-ROLLERS

YV. THE HALICTI

XIT. THE HALICTI : THE FORTRESS - $\quad$ - $\quad 210$

XVII. THE LANGUEDOCIAN SCORPION $\quad-\quad \ldots \quad$ - $\quad 223$

XVIII. THE LANGUEDOCIAN SCORPION: THE FAMILY - - 243

vii 



\section{LIST OF ILLUSTRATIONS}

PLATE I.-1. The Sacred Beetle. 2. The Sacred Beetle rolling his pill. 3. Rolling the pill to the eating burrow - - Frontispiece

PLATE II.-Burrow and pear-shaped ball of the Sacred Beetle facing 20

FIG. 1.-Section of the Sacred Beetle's pill, showing the egg and the hatching-chamber - $\quad$ - $\quad$ - $\quad$ -

PLATE III.-1. The Sacred Beetle pushing away and overturning a thieving friend who tries to force his assistance upon him. 2. Crypt

in which the Beetle shapes a grub's provision into a pear - facing 36

Fig. 2. - The Sacred Beetle's pill dug out cupwise to receive the egg - 39

Fig. 3. - Grub of the Sacred Bectle - _ - _ - - 46

FIg. 4. - Digestive apparatus of the Sacred Beetle - $\quad . \quad 47$

PLATE IV. -1 and 2. The Spanish Copris, male and female. 3. The pair jointly kneading the big loaf, which, divided into egg-shaped pills, will furnish provisions for each grub of the brood. 4. The mother alone in her burrow: five pills are already finished; a sixth is in process of construction - _ _ _ - facing 72

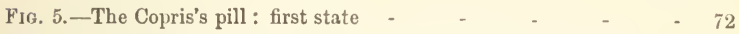

Fig. 6.-The Spanish Copris's pill dug out cupwise to receive the egg - 73

Fig. 7.-The Spanish Copris's pill : section showing the hatching.

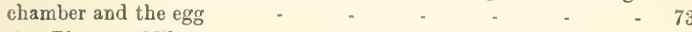

Fig. 8.-Phanæus Milo - $\quad$ - $\quad$ - $\quad$ - $\quad$ - 102

FIG. 9.-Work of Phanæus Milo. A, the whole piece, actual size. B, the same opened, showing the pill of sausage-meat, the clay gourd, the chamber containing the egg and the ventilating-shaft - 104

Fig. 10.-Work of Phanæus Milo : the largest of the gourds observed (natural size) 
PLATE V.-1. Onthophagus Taurus. 2. Onthophagus Vacca. 3. The Stercoraceous Geotrupe. 4. The Wide-necked Scarab. 5. Cleonus Ophthalmicus, 6. Cerceris Tuberculata. 7. Buprestio Erea facing 80

Fic. 11.-The Stercoraceous Geotrupe's sausage

Fic. 12,-Section of the Stercoraceous Geotrupe's sausage at its lower end, showing the egg and the hatching-chamber

PLATE VI.-Minotarrus Typhous, male and female. Excavating Minotaurus' burrow - $\quad$ - $\quad$ - $\quad$ - $\quad . \quad$. facing 132

PLATE VII.-The Minotaurus couple engaged on miller's and baker's work -

PLATE VIII.-1. The Common or Garden Scolia. 2. The Twobanded Scolia. 3. Grub of Cetonia Aurata progressing on its back. 4. The Two-banded Scolia paralyzing a Cetonia grub. 5. Cetonia grubs progressing on their baeks, with their legs in the air ; two are in a resting position, rolled up

PLATE IX.-1. Lycosa Narbonensis. 2. The Ringed Calicurgus. 3. Ammophila Hirsuta. 4. Ammophila Sabulosa. 5. Scroll of Lihynchites Vitis. 6. Scroll of Rhynchites Populi -

- facing 162

PLATE X.-The large glass case containing the Seorpions

- facing 226

PLATE XI.-1. Nuptial allurements, showing "the straight bend." 2. The wedding stroll. 3. The couple enter the nuptial

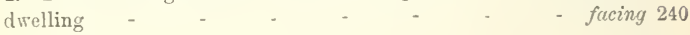

PLATE XII.-1. The Languedocian Scorpion devouring a cricket. 2. After pairing-time: the female feasting on her Scorpion. 3. The mother and lier family, with emancipation-time at hand - 


\section{THE SACRED BEE'TLE}





\title{
THE LIFE AND LOVE OF THE INSECT
}

\author{
CHAPTER I
}

THE SACRED BEETLE

THE building of the nest, the safeguard of the family, furnishes the loftiest expression of the instinctive faeulties. That ingenious architect, the bird, teaches us as much; and the insect, with its still more varied talents, repeats the lesson, telling us that maternity is the supreme inspirer of the instinct. Placed in eharge of the duration of the speeies, which is of more serious interest than the preservation of individuals, maternity awakens a marvellous foresight in the drowsiest intelligence; it is the thrice saered hearth wherein smoulder and then suddenly burst forth those incomprehensible psychic gleams which give us tho impression of an infallible reasoning power. The more maternity asserts itself, the higher does instinct ascend.

The most worthy of our attention in this respect are the Hymenoptera, upon whom the eares of maternity devolve in their fulness. All these favourites of instinct prepare board and lodging for their offspring. They become past masters in a host of industries for the sake of a family which their faceted eyes never behold and 
which, neverthcless, the maternal foresight knows quite well. One becomes a manufacturer of cotton goods and mills cotton-wool bottles; another sets up as a basketmaker and weaves hampers out of scraps of flowers; a third turns mason and builds rooms of cement and domes of road-metal ; a fourth starts a pottery-works, in which the elay is kneaded into shapely vases and jars and bulging pots; yet another adopts the calling of a pitman and digs mysterious warm, moist passages underground. A thousand trades similar to ours and often even unknown to our industrial system are employed in the preparation of the abode. Next come the victuals of the expected nurslings : piles of honey, loaves of pollen, stores of preserved game, cunningly paralyzed. In such works as these, having the future of the family for their exclusive object, the highest manifestations of the instinct are displayed under the impulse of maternity.

In the rest of the entomological order, the mother's cares are generally very summary. In most cases, they are confined to the laying of the eggs in favourable spots, where the grub can find a bed and food at its own risk and peril. Where education is so rustic, talents are superfluous. Lycurgus banished the arts from his republic, as enervating. In like manner, the higher inspirations of the instinct are banished among insects brought up in Spartan simplicity. The mother neglects the gentle cares of the cradle; and the prerogatives of the intellect, the best of all, diminish and disappear, so true is it that for the animal, even as for ourselves, the family is a source of perfection.

While the Hymenoptera, so extremely thoughtful of their progeny, fill us with wonder, the others, which abandon theirs to the chances of good luck or bad, must seem 
to us, by comparison, of but little interest. These others form almost the entirety; at least, to my knowledge, among the fauna of our country-sides, there is only one other instance of insects preparing board and lodging for their family, as do the gatherers of honey and the buriers of baskets full of game.

And, strange to say, those insects vying in maternal tenderness with the flower-despoiling tribe of Bees are none other than the Dung-beetles, the dealers in ordure, the scavengers of the meadows contaminated by the herd. We must pass from the scented corollas of the flower-bed to the droppings left on the high-road by the mule to find a second example of devoted mothers and lofty instincts. Nature abounds in these antitheses. What are our ugliness and beauty, our cleanliness and dirt to her? With refuse, she creates the flower; from a little manure, she extracts the blessed grain of the wheat.

Notwithstanding their filthy trade, the Dung-beetles occupy a very respectable rank. Thanks to their usually imposing size; to their severe and irreproachably glossy garb ; to their short, stout, thickset shape ; to the quaint ornamentation either of their brow or, also, of their thorax, they cut an excellent figure in the collector's boxes, especially when to our own species, oftenest of an ebon black, we add a few tropical species flashing with gleams of gold and ruddy copper.

They are the sedulous guests of our herds, for which reason several of them emit a mild flavour of benzoic acid, the aromatic of the sheepfolds. Their pastoral habits have impressed the nomenclators, who, too often, alas, careless of euphony, have changed their note this time and headed their descriptions with such names as Melibæus, Tityrus, Amyntas, Corydon, Mopsus and Alexis. 
We have here the whole series of bucolic denominations made famous by the poets of antiquity. Virgil's eclogues have lent their vocabulary for the Dung-beetles' glorification.

What alacrity around one and the same dropping! Never did adventurers hurrying from the four corners of the earth display such eagerness in working a Californian claim. Before the sun becomes too hot, they are there in their hundreds, large and small, promiseuonsly, of every sort, shape and size, hastening to carve themselves a slice of the common cake. There are some that work in the open air and scrape the surface; there are some that dig themselves galleries in the thick of the heap, in search of choice veins; others work the lower stratum and bury their spoil without delay in the underlying ground; others-the smallest-stand aside to crumble a morsel that has fallen from the mighty excavations of their more powerful fellow-workers. Some, the newcomers and, no doubt, the liungriest, consume their meal on the spot; but the greater number mean to put by a substance that will allow them to spend long days in plenty, down in some safe retreat. A nice, fresh dropping is not found just when you want it, amid the fields bare of thyme; a windfall of that sort is as manna from the sky; only fortune's favourites receive so fair a portion. Wherefore the riches of to-day are prudently stored for the morrow.

The stercoraceous scent has carried the glad tidings half a mile around; and all have hastened up to gather provisions. A few laggards are still arriving, a-wing or on foot.

Who is this that trots towards the heap, fearing lest he cume tou late? His long legs move with a sudden, 
awkward action, as though driven by some mechanism within his belly; his little red antennæ spread their fan, a sign of anxious greed. He is coming, he has come, not without sending some few banqueters sprawling. It is the Sacred Beetle, clad all in black, the biggest and most famous of our Dung-beetles. Ancient Egypt held him in veneration and looked upon him as a symbol of immortality. Here he now sits at table, beside his fellowguests, each of whom is giving the last touches to his ball with the flat of his broad fore-legs or else enriching it with yet one more layer before retiring to enjoy the fruit of his labours in peace. Let us follow the construction of the famous ball in all its phases.

The shield, that is to say, the broad, flat edge of the head, is notched with six angular teeth arranged in a semicircle. This constitutes the tool for digging and separating, the rake that lifts and casts aside the unnutritious regetable fibres, goes for something better, scrapes and collects it together. A choice is thus made, for these dainty epicures differentiate between one thing and another : a casual choice, if the Beetle be interested in his own provender, but a most serupulous choice, when it beeomes a question of construeting the maternal ball.

For his own needs, the Beetle is less fastidious and contents himself with a wholesale selection. The notched shield scoops and digs, eliminates and gathers somewhat at random. The fore-legs play a mighty part in the work. They are flattened, curved into the segment of a circle, supplied with powerful nervures and armed on the outside with five sturdy teeth. If a powerful effort be needed to remove an obstacle or to force a way through the thickest part of the heap, the Dung-beetle makes 
play with his elbows, that is to say, he flings his toothed legs to right and left and clears a semi-circular space with a vigorous thrust of the rake. Room once made, a different kind of work is found for these same limbs : they collect armfuls of the material raked together by the shield and push it under the insect's belly, between the four hind-legs. These are shaped for the turner's trade. The legs, especially the last two, are long and slender, slightly bowed and ending in a very sharp claw. One has but to look at them to recognize a pair of spherical compasses capable of embracing a globular body in their curved branches and improving its form. In fact, their mission is to shape the ball.

Armful by armful, the material is heaped up under the belly, between the four legs, which, by a slight pressure, impart their own curve to it and give it a first fashion. Then, betweenwhiles, the rough-hewn pill is set spinning betwixt the four branches of the two spherical compasses; it turns under the Dung-beetle's belly until it is rolled into a perfect ball. Should the surface layer lack plasticity and threaten to peel off, should some toostringy part refuse to yield to the action of the wheel, the fore-legs correct the faulty places; their broad beaters pat the ball to give consistency to the new layer and to imbed the recalcitrant scraps into the mass.

Under a hot sun, when the work is urgent, one stands amazed at the turner's feverish activity. And thus the business proceeds apace : what was but lately a scanty pellet is now a ball the size of a walnut; soon it will be a ball the size of an apple. I have seen greedy-guts manufacture a ball the size of one's fist. Here, of a certainty, is food in the larder for days to come !

The provisions are made. The next thing is to withdraw 
from the fray and carry the victuals to a fitting place. Here the most striking characteristics of the Searab begin to show themselves. The Dung-beetle sets out without delay; he embraces the sphere with his two long hindlegs, whose terminal claws, planted in the mass, serve as rotatory pivots; he obtains a purchase with the middle pair of legs ; and, using the armlets of his fore-legs for leverage, he travels backwards with his load, bending his body, with his head down and his hinder part in the air. The hind-legs, the principal factor in the machinery, move continually, coming and going, shifting the claws to change the axis of rotation, maintain the equilibrium of the load and push it on by alternate thrusts to right and left. In this way, the ball finds itself touehing the ground by turns with every point of its surface, a process which perfeets its shape and gives an even consistency to its outer layer by means of pressure uniformly divided.

And now, cheerily! It moves, it rolls; we shall get there, though not without accident. Here is a first difficult step : the Beetle is wending his way athwart a slope and the heavy mass tends to follow the incline; but the insect, for reasons best known to itself, prefers to cut across this natural road, a bold plan which a false step or a grain of sand disturbing the balance may defeat. The false step is made; the ball rolls to the bottom of the valley; and the inseet, toppled over by the impetus of its load, kicks about, gets up on its legs again and hastens to harness itself once more. The meehanism is working better than ever. But look out, you scatterbrain! Follow the dip of the valley : that will save you labour and mishap; the road is good and level; your ball will roll quite easily. Not a bit of it! The insect prepares once more to mount the slope that was already 
its undoing. Perhaps it suits it to return to the heights. Against that I have nothing to say : the Scarab's opinion is more far-seeing than mine as to the advisability of keeping to lofty regions. But, at least, take this path, which will lead you up by a gentle incline! Not at all! If he find himself near some very steep slope, impossible to climb, that is what the obstinate fellow prefers. And now begins a labour of Sisyphus. The ball, that enormous burden, is painfully hoisted, step by step, with infinite precautions, to a certain height, always backwards. I ask myself by what static miracle so great a mass can be kept upon the slope. Oh! An ill-planned movement frustrates all this toil : the ball comes down, dragging the beetle with it! The escalade is repeated, soon to be followed by another fall. The attempt is renewed, better-managed this time at the difficult points; a confounded grass-root, the cause of the previous tumbles, is carefully turned. We are almost there; but gently, gently! The ascent is dangerous and a mere nothing may yet spoil all. For see, a leg slips on a smooth bit of gravel! Down come ball and Dung-beetle, all mixed up together. And the Beetle begins over again, with indefatigable persistency. Ten times, a score of times, he will attempt the thankless ascent, until his obstinacy vanquishes all obstacles, or until, recognizing the uselessness of his efforts, he takes to the level road.

The Scarab does not always push his precious ball alone : sometimes he takes a partner; or, to be accurate, the partner takes him. This is how the thing usually happens : once his ball is ready, a Dung-beetle issues from the crowd and leaves the work-yard, pushing his spoil behind him. A neighbour, one of the newcomers, whose own task is hardly begun, suddenly drops his work and 
runs to the ball now rolling, to lend a hand to the lucky owner, who seems to accept the proffered aid kindly. Henceforth, the two cronies work as partners. Each does his best to push the pellet to a place of safety. Was a compact really concluded in the work-yard, a tacit agreement to share the cake betwcen them? While one was kneading and moulding the ball, was the other tapping rich veins whence to extract choice materials and add them to the common store? I have never observed such a collaboration; I have always seen each Dung-beetle occupied solely with his own affairs in the works. The last-comer, therefore, has no acquired rights.

Is it, then, a partnership between the two sexes, a couple intending to set up house? I thought so for a time. The two beetles, one before, one behind, pushing the heavy ball with equal zeal, reminded me of a song which the barrel-organs used to grind out some years ago :

Pour monter notre menage, hélas! comment feront-nous?

Toi devant et moi derrière, nous pousserons le tonneau. ${ }^{1}$

The evidence of the scalpel compelled me to abandon this domestic idyll. There is no outward difference between the two scxes in the Dung-beetle. I, therefore, dissected the two beetles engaged in conveying one and the same ball; and they often proved to belong to the same sex.

Neither community of family nor community of toil ! Then what is the motive for this apparent partnership? It is just simply an attempt at robbery. The eager fellow-worker, under the deceitful pretence of lending a helpful hand, nurses the scheme of purloining the ball at

1 "When you and I start housekeeping, alas, what shall we do? You in front and I behind, we'll shove the tub along !" 
the first opportunity. To make one's own ball at the heap implies drudgery and patience; to steal one ready-made, or at least to foist one's self as a guest, is a much easier matter. Should the owner's vigilance slacken, you can run away with the treasure; should you be too closely watched, you can sit down to table uninvited, pleading services rendered. It is, "Heads I win, tails you lose," in these tactics, so that pillage is exercised as one of the most lucrative of trades. Some go to work craftily, in the way I have just described: they come to the aid of a comrade who has not the least need of them and hide a most indelicate greed under the cloak of charitable assistance. Others, bolder perhaps, more confident in their strength, go straight to the goal and commit robbery with riolence.

Scenes are constantly happening such as this : a Scarab walks off, peacefully and alone, rolling his ball, his lawful property, acquired by conscientious work. Another comes flying up, I know not whence, drops down heavily, folds his smoky wings under their elytra and, with the back of his toothed armlets, knocks over the owner, who is powerless to ward off the attack in his harnessed posture. While the dispossessed one struggles to his fect, the other perches himself atop the ball, the best position from which to repel the assailant. With his armlets folded under his breast, ready at all points, he awaits events. The victim of the theft mores round the ball, seeking a favourable spot at which to attempt the assault; the thief spins round on the roof of the citadel, constantly facing him. If the first raise himself in order to scale the wall, the second gives him a cuff that stretches him on his back. Safe at the top of his fortress, the besieged Bectle would baffle his adversary's attempts indefinitely, 
if the latter did not change his tactics to recover his property. Sapping is brought into play to bring down the citadel with the garrison. The ball, shaken from below, staggers and rolls, carrying with it the robber, who makes violent efforts to maintain his position on the top. This he succeeds in doing, though not always, thanks to hurried feats of gymnastics that enable him to regain a level from which the rolling of his support tends to drive him. Should a false movement bring him to the ground, the chances become equal and the struggle turns into a wrestling-match. Robber and robbed grapple at close quarters, breast to breast. Their legs twist and untwist, their joints intertwine, their horny armour clashes and grinds with the rasping sound of filed metal. Then that one of the two who succeeds in throwing his adversary and releasing himself hurriedly takes up a position on the top of the ball. The siege is renewed, now by the robber, now by the robbed, as the chances of the hand-to-hand conflict may have determined. The former, no doubt a hardy filibuster and adventurer, often has the best of the fight. Then, after two or three defeats, the ejeeted Beetle wearies and returns philosophically to the heap, there to make himself a new pellet. As for the other, with all fear of a surprise at an end, he harnesses himself to the conquered ball and pushes it whither he pleases. I have sometimes seen a third thief appear upon the scene and rob the robber. Nor can I honestly say that I was sorry.

I ask myself in vain what Proudhon ${ }^{1}$ introduced into Beetle-morality the daring paradox that "property is based on plunder," or what diplomatist taught Dungbeetles the savage maxim that " might is right." I have

1 Jean Baptiste Victor Proudhon (1758-1838), author of De la dis. tinction des biens, Traité du domaine public, etc.-Translator's Note. 


\section{THE LIFE AND LOVE OF THE INSECT}

no faets whereby to trace the origin of these spoliations whieh have become a custom, of this abuse of strength to eapture a lump of ordure. All that I can say is that theft is in general use among the Scarab tribe. These Dung-rollers rob one another among themselves with a ealm effrontery of which I know no other instanee. I leave it to future observers to elueidate this eurious problem in animal psyehology and I return to the two partners rolling their ball in eoneert.

Let us call the two fellow-workers partners, although that is not the proper name for them, seeing that the one forces himself upon the other, who probably aecepts outside help only for fear of a worse evil. The meeting, however, is absolutely peaceful. The Beetle owning the ball does not cease work for an instant at the arrival of his assistant; and the neweomer seems animated by the best intentions and sets to work on the spot. The way in which the two partners harness themselves differs. The owner oceupies the ehief position, the place of honour : he pushes behind the load, with his hind-legs in the air and his head down. The assistant is in front, in the reverse position, head up, toothed arms on the ball, long hind-legs on the ground. Between the two, the ball rolls along, pushed before him by the first, dragged towards him by the seeond.

The efforts of the couple are not always very harmonious, the more so as the helper has his back to the road to be traversed, while the owner's view is impeded by the load. Hence arise constant accidents, absurd tumbles, taken eheerfully and in good part : each picks himself up quickly and resumes the same position as before. On level ground, this system of draught does not correspond with the dynamic force expended, for 
lack of precision in the combined movements : the Scarab at the back would do as well and better if left to himself. And so the helper, after giving a proof of his good-will at the risk of disturbing the mechanism, decides to keep still, without, of course, abandoning the precious ball, which he already looks upon as his : finding is keeping; a ball touched is a ball gained. He will commit no such imprudence : the other might give him the slip!

$\mathrm{He}$, therefore, gathers his legs under his belly, flattens himself, encrusts himself, so to speak, on the ball and becomes one with it. Henceforth, the whole concernball and Beetle clinging to its surface-rolls along, pushed by the lawful owner. Whether the load passes over his body, whether he occupies the top, the bottom or the side of the rolling burden matters little to the intruder, who sits tight and lies low. A singular helper this, who has himself driven in a carriage to secure his share of the victuals!

But a steep ascent heaves in sight and gives him a fine part to play. He now, on the stiff slope, takes the lead, holding the heavy mass with his toothed arms, while his mate seeks a purchase to hoist the load a little higher. Thus, by a combination of well-managed efforts, the one above gripping, the one below pushing, I have seen them together mount acclivities where the stubborn determination of one alone would have come to naught. But not all have the same zeal at these difficult moments : there are some who, on slopes where their assistance is most needed, seem not in the least aware of the difficulties to overcome. While the unhappy Sisyphus exhausts himself in endeavours to pass the dangerous place, the other quietly leaves him to do his best and, himself encrusted on the ball, rolls down with it, when it comes to grief, and is hoisted up with it anew. 


\section{THE LIFE AND LOVE OF THE INSECT}

Let us suppose the Scarab fortunate enough to have found a loyal partner ; or, better still, let us suppose that he has met no self-invited colleague. The burrow is ready. It is a cavity dug in soft earth, usually in sand, shallow, the size of one's fist and communicating with the outside by a short channel just large enough for the passage of the ball. As soon as the provisions are safely housed, the Scarab shuts himself in by stopping up the entrance to his dwelling with rubbish reserved for the purpose in a corner. Once the door is closed, no sign outside betrays the banqueting-hall. And, now, welcome mirth and jollity! All is for the best in the best of all possible worlds! The table is sumptuously laid; the ceiling tempers the heat of the sun and allows but a mild, moist heat to penetrate; the calm, the darkness, the concert of the crickets overhead all favour the digestive functions. So great has been my illusion that I have caught myself listening at the door, expecting to hear the revellers burst into that famous snatch from the opera of Galatée : ${ }^{1}$

Ah! qu'il est doux de ne rien faire

Quand tout s'agite autour de nous. ${ }^{2}$

Who would dare disturb the bliss of such a banquet? But the wish to learn is eapable of all things ; and I had the courage. I will set down here the result of my violations of the sanctity of domestic life : the ball by itself fills almost the whole of the room; the rich repast rises from floor to ceiling. A narrow passage runs between it and the walls. Here sit the banqueters, two at

1 A light opera, with music by Victor Massé and libretto by Jules Barbier and Michel Carré (1852).-Translator's Note.

2 "Ah, how sweet is far niente, When round us throbs the busy world!" 
most, very often but one, belly to table, back to the wall. Once the seat is chosen, no one stirs ; all the vital forces are absorbed by the digestive faculties. No little movements, which might cause the loss of a mouthful; no dainty toying with the food, which might cause the waste of some. Everything has to pass, properly and in order. To see them so pensively seated around a ball of dung, one would think that they were aware of their task as scavengers of the earth and that they consciously devoted themselves to that marvellous chemistry which out of filth brings forth the flower, the joy of our eyes, and the Beetles' elytra, the ornament of our lawns in spring. For the purpose of this transcendental work, which is to turn into live matter the residue discarded by the horse and the mule, despite the perfection of their digestive organs, the Dung-bcetle must needs be specially equipped. And, in point of fact, anatomy compels us to admire the prodigious length of his intestine, which, folded and refolded upon itself, slowly elaborates the materials in its profuse circuits and exhausts them to the very last serviceable atom. From that whence the stomach of the herbivorous animal has been able to extract nothing, this powerful alembic wrings riches that, at a mere touch, turn into ebon armour in the Sacred Scarab and a breastplate of gold and rubies in other Dung-beetles.

Now this wonderful metamorphosis of ordure has to be accomplished in the shortest possible time : the general health demands it. And so the Scarab is endowed with matchless digestive powers. Once housed in the company of food, day and night he will not cease eating and digesting until the provisions be exhausted. It is easy, with a little practice, to bring up the Scarab in captivity, in a volery. In this way, I obtained the following evi- 


\section{6

dence, which will tell us of the high digestive capacity of the famous Dung-beetle.

When the whole ball has been through the mill, the hermit reappears in the light of day, seeks his fortune, finds it, shapes himself a new ball and begins all over again. On a very hot, calm, sultry day-the atmospheric conditions most favourable to the gastronomic enjoyments of my anchorites-watch in hand, I observe one of the consumers in the open air, from eight o'clock in the morning until eight o'clock at night. The Scarab appears to have come across a morsel greatly to his taste, for, during those twelve hours, he never stops feasting, remains permanently at table, stationary at one spot. At eight $o$ 'clock in the erening, I pay him a last visit. His appetite seems undiminished. I find the glutton in as fine fettle as at the start. The banquet, therefore, must have lasted some time longer, until the total disappearance of the lump. Next morning, in fact, the Scarab is gone and, of the fine piece attacked on the previous day, naught remains but crumbs.

Once round the clock and more, for a single sitting at table, is a fine display of gormandizing in itself ; but here is something much better by way of rapidity of digestion. While, in front of the insect, the matter is being continuously chewed and swallowed, behind it, with equal continuity, the matter reappears, stripped of its nutritive particles and spun into a little black cord, similar to a cobbler's thread. The Scarab never evacuates except at table, so quickly are his digestive labours performed. The apparatus begins to work at the first few mouthfuls; it ceases its office soon after the last. Without a break from beginning to end of the meal and always hanging to the discharging orifice, the thin cord is piled in a 
heap which is easy to unroll so long as it is not dried up.

The thing works with the regularity of a chronometer. Every minute, or, rather, to be accurate, every four-andfifty seconds, an eruption takes place and the thread is lengthened by three to four millimetres. ${ }^{1}$ At long intervals, I employ the pincers, unfasten the cord and unroll the heap along a graduated rule, to estimate the produce. The total measurement for twelve hours is 2.88 metres. $^{2}$ As the meal and its necessary complement, the work of the digestive apparatus, went on for some time longer after my last visit, paid at eight o'clock in the evening by the light of a lantern, it follows that my subject must have spun an unbroken stercoraceous cord well over three yards in length.

Given the diameter and the length of the thread, it is easy to calculate its volume. Nor is it clifficult to arrive at the exact volume of the insect by measuring the amount of water which it displaces when immersed in a narrow cylinder. The figures thus obtained are not uninteresting : they tell us that, at a single festive sitting, in a dozen hours, the Scarab digests very nearly its own volume in food. What a stomach! And especially what a rapidity, what a power of digestion! From the first mouthfuls, the residuum forms itself into a thread that stretches, stretches out indefinitely as long as the meal lasts. In that amazing laboratory, which perhaps never puts up its shutters, unless it be when victuals are lacking, the material only passes through, is worked upon at once by the reagents in the stomach and at once exhausted. We may well believe that a crucible so quick to purify dirt plays its part in the general hygiene.

$1 \cdot 11$ to 15 inches. - Translator's Note.

2 Close upon $9 \frac{1}{2}$ feet. - Translator's Note. 


\section{CHAPTER II}

THE SACRED BEETLE: THE PEAR

A young shepherd, who had been told in his spare time to watch the doings of the Sacred Beetle, came to me in high spirits, one Sunday, in the second half of June, to say that he thought the time had come to eommence a search. He had detected the insect issuing from the ground, had dug at the spot where it made its appearance and had found, at no great depth, the queer thing which he was bringing me.

Queer it was and calculated to upset the little which I thought I knew. In shape, it was exaetly like a tiny pear that had lost all the colour of its freshness and turned brown in rotting. What could this curious object be, this pretty plaything that seemed to come from a turner's workshop? Was it made by human hands? Was it a model of the fruit of the pear-tree intended for some child's colleetion? One would say so.

The children come round me ; they look at the treasuretrove with longing eyes; they would like to add it to the contents of their toy-box. It is much prettier in shape than an agate marble, much more graceful than an ivory egg or a box-wood top. The material, it is true, seems none too nicely chosen; but it is firm to the touch and very artistically eurved. In any case, the little pear discovered underground must not go to swell the collection of nursery treasures until we have found out more about it. 
Can it really be the Scarab's work? Is there an egg inside it, a grub? The shepherd assures me that there is. A similar pear, crushed by accident in the digging, contained, he says, a white egg, the size of a grain of wheat. I dare not believe it, so greatly does the object which he has brought me differ from the ball which I expected to see.

To open the puzzling "find" and ascertain its contents would perhaps be imprudent: such an act of violence might jeopardize the life of the germ enclosed, always provided that the Scarab's egg be there, a matter of which the shepherd seems convinced. And then, I imagine, the pear-shape, opposed to every accepted idea, is probably accidental. Who knows if chance has anything like it in store for me in the future? It were wise to keep the thing as it is, to await events; above all, it were wise to go in scarch of information on the spot.

The shepherd was at his post by daybreak the next morning. I joined him on some slopes that had been lately cleared of their trees, where the hot summer sun, which strikes so powerfully on the neck, could not reach us for two or three hours. In the cool air of morning, with the flock browsing under the care of the sheep-dog, we went in search together.

Scarabæus' burrow is soon found : it is recognizable by the recent mole-hill that surmounts it. My companion digs with a vigorous wrist. I have lent him my little pocket-trowel, the light, but workmanlike tool which, incorrigible earth-scraper that I am, I seldom omit to take with me when I go out. I lie down, the better to see the arrangement and furnishing of the hypogeum in process of excavation; and I am all eyes. The 
shepherd uses the trowel as a lever and, with his free hand, pushes baek the rubbish.

Here we are! A cave opens out and, in the moist warmth of the yawning vault, I see a splendid pear lying full-length upon the ground. I shall certainly long remember this first revelation of the maternal work of the Scarab. My exeitement could have been no greater were I an arehæologist digging among the aneient relies of Egypt and lighting upon the saered inseet of the dead, carved in emerald, in some Pharaonic crypt. O blessed joys of truth suddenly shining forth, what others are there to compare with you! The shepherd was in the seventh heaven: he laughed in response to my smile and was happy in my gladness.

Luek does not repeat itself: "Non bis in idem," says the old adage. And here have I twice had under my eyes this curious shape of the pear. Could it be the normal shape, not subjeet to exeeption? Must we abandon all thought of a sphere similar to those which the inseet rolls on the ground? Let us continue and we shall see. A seeond hole is found. Like the previous one, it contains a pear. The two diseoveries are as like as two peas; they might have issued from the same mould. And a valuable detail is this : in the seeond burrow, beside the pear and lovingly embraeing it, is the mother Beetle, engaged, no doubt, in giving it the finishing touches before leaving the underground eave for good. All doubts are dispelled : I know the worker and I know the work.

The rest of the morning confirmed these premisses to the full : before an intolerable sun drove me from the slope explored, I possessed a dozen pears identical in shape and almost in dimensions. On various oecasions, the mother was present in the workshop. 


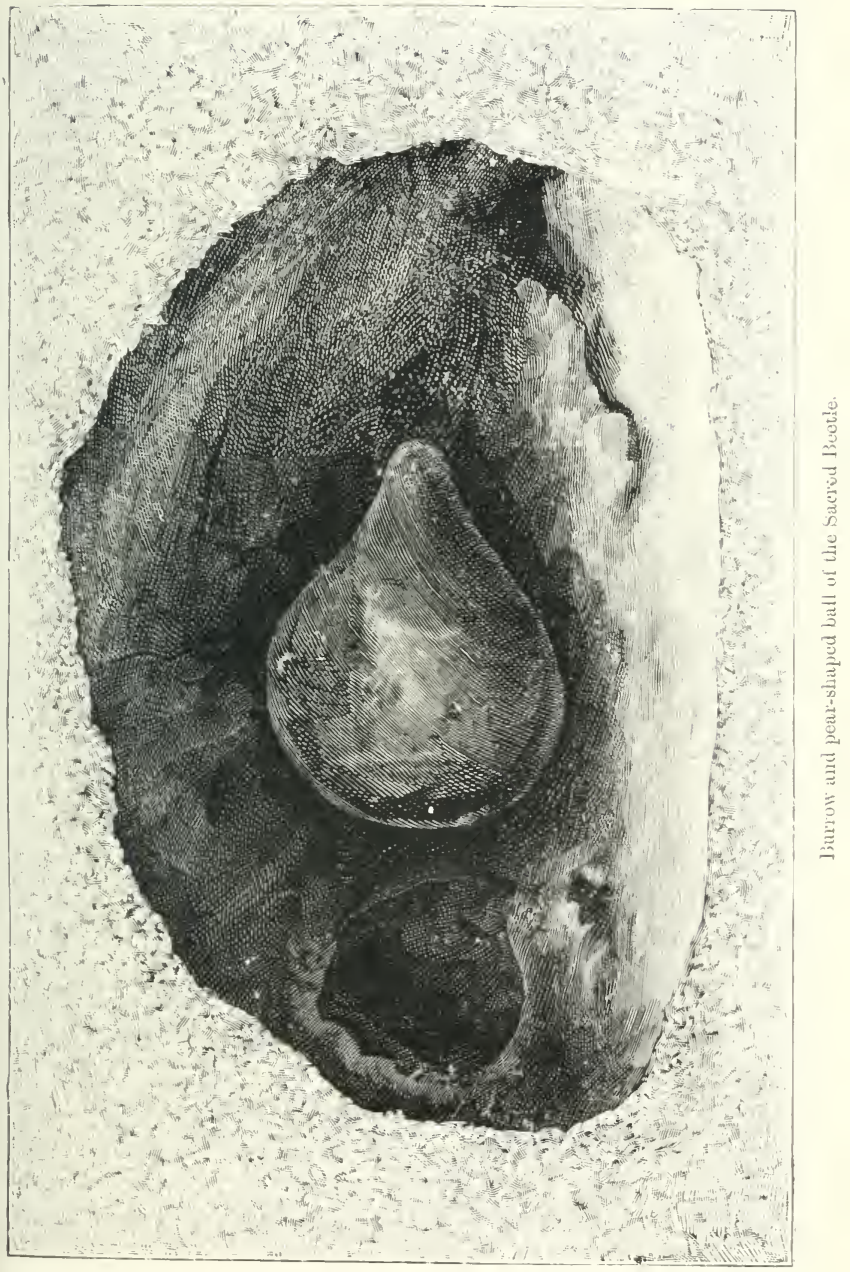



Let me tell, to finish with this part of our subject, what the future held in store for me. During the whole of the dog-days, from the end of June until September, I renewed almost daily my visits to the spots frequented by the Scarab ; and the burrows dug up with my trowel supplied me with an amount of evidence exceeding my fondest hopes. The insects brought up in the volery supplied me with further documents, though these, it is true, were rare and not to be compared with the riches of the open fields. All told, at least some hundred nests passed through my hands ; and it was always the graceful shape of the pear, never, absolutely never, the round shape of the pill, never the ball of which the books tell us.

And now let us unfold the authentie story, calling to witness none save facts actually observed and reobserved. The Sacred Beetle's nest is betrayed on the outside by a heap of shifted earth, by a little mole-hill formed of the superfluous rubbish which the mother, when elosing up the abode, has been unable to replace, as a part of the excavation must be left empty. Under this heap is a shallow pit, about two-fifths of an inch deep, followed by a horizontal gallery, either straight or winding, which ends in a large hall, spacious enough to hold a man's fist. This is the crypt in which the egg lies wrapped in food and subjected to the incubation of a burning sun, at a few inches underground; this is the roomy workshop in which the mother, enjoying full liberty of movement, has kneaded and shaped the future nursling's bread into a pear.

This stercoral bread has its main axis lying in a horizontal position. Its shape and size remind one exactly of those little poires de Saint-Jean which, thanks to their bright colouring, their flavour and their early ripeness, 
delight the children's tribe. The bulk varies within narrow limits. The largest dimensions are 45 millimetres in length by 30 millimetres in width $;^{1}$ the smallest are 35 millimetres by $28 .^{2}$

Without being as polished as stucco, the surface, which is absolutely regular, is carefully smoothed under a thin layer of red earth. At first, when of recent construction, soft as potter's clay, the pyriform loaf soon, in the course of desiccation, acquires a stout crust that refuses to yield under the pressure of fingers. Wood itself is no harder. This bark is the defensive wrapper which isolates the recluse from this world and allows him to consume his victuals in profound peace. But, should desiccation reach the central mass, then the danger becomes extremely serious. We shall have occasion to return to the woes of the grub exposed to a diet of toostale bread.

What dough does the Scarab's bake-house use? Who are the purveyors? The mule and the horse? By no means. And yet I expected to find it so-and so would everybody-at seeing the insect draw so eagerly, for its own use, upon the plentiful garner of an ordinary lump of dung. For that is where it habitually manufactures the rolling ball which it goes and consumes in some underground retreat.

Whereas coarse bread, crammed with bits of hay, is good enough for the mother, she becomes more dainty where her family are concerned. She now wants fine pastry, rich in nourishment and easily digested ; she now wants the ovine manna: not that which the sheep of a dry habit scatters in trails of black olives, but that which,

$11.8 \times 1.4$ inches. - Translator's Note.

$21.4 \times 1.1$ inches. - Translator's Note. 
elaborated in a less parched intestine, is kneaded into biscuits all of a piece. That is the material required, the dough exclusively used. It is no longer the poor and stringy produce of the horse, but an unctuous, plastic, homogeneous thing, soaked through and through with nourishing juices. Its plasticity, its delicacy are admirably adapted to the artistic work of the pear, while its alimentary qualities suit the weak stomach of the newborn progeny. Little though the bulk be, the grub will here find sufficient food.

This explains the smallness of the alimentary pears, a smallness that made me doubt the origin of my find, before I came upon the mother in the presence of the provisions. I was unable to see in those little pears the bill of fare of a future Sacred Beetle, himself so great a glutton and of so remarkable a size.

Where is the egg in that nutritive mass so norel in shape? One would be inclined to place it in the centre of the fat, round paunch. This central point is best-protected against accidents from the outside, best-endowed with an even temperature. Besides, the budding grub would here find a deep layer of food on every side of it and would not be exposed to the mistakes of the first few mouthfuls. Everything being alike on every side of it, it would not be called upon to choose ; wherever it chanced to apply its novice tooth, it could continue without hesitation its first dainty repast.

All this seemed so very reasonable that I allowed myself to be led away by it. In the first pear which I explored, slender layer by slender layer, with the blade of a penknife, I looked for the egg in the centre of the paunch, feeling almost certain of finding it there. To my great surprise, it was not there. Instead of being hollow, the 


\section{THE LIFE AND LOVE OF THE INSECT}

centre of the pear is full and consists of one continuous, homogeneous alimentary mass.

My deductions, which any observer in my place would certainly have shared, seemed very reasonable; the Scarab, however, is of another way of thinking. We have our logic, of which we are rather proud; the Dungkneader has hers, which is better than ours in this contingency. She has her own foresight, her own discernment

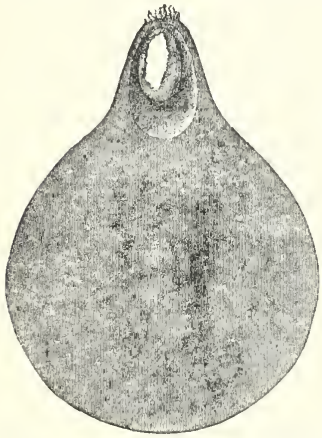

Fic, 1.-Section of the Sacred Beetle's pill, showing the egg and the hatehing-chamber. of things; and she places her egg elsewhere.

But where? Why, in the narrow part of the pear, in the neck, right at the end. Let us cut this neck lengthwise, taking the necessary precautions, so as not to damage the contents. It is hollowed into a recess with polished and shiny walls. This is the tabernacle of the germ, the hatching-chamber. The egg, which is very large in proportion to the size of the layer, is a long white oval, about 10 millimetres in length by 5 millimetres in its greatest width. ${ }^{1}$ A slight empty space separates it on all sides from the chamber-walls. There is no contact with these walls, save at the rear end, which adheres to the top of the recess. Lying horizontally, following the normal position of the pear, the whole of it, excepting the point of attachment, rests upon an air-mattress, most elastic and warmest of beds. Let

$1 \cdot 4 \times \cdot 2$ inches. - Translator's Note. 
us observe also that the top of the nipple, instead of being smooth and compact like the rest of the pear, is formed of a felt of particles of scrapings, which allows the air sufficient access for the breathing-needs of the egg.

We are now informed. Let us next try to understand the Scarab's logic. Let us account for the necessity for the pear, that form so strange in entomological industry; let us seek to explain the convenience of the curious situation of the egg. It is dangerous, I know, to venture upon the how and wherefore of things. We easily sink in this mysterious domain where the moving soil gives way beneath the feet, swallowing the foolhardy in the quicksands of error. Must we abandon such excursions, because of the risk? Why should we?

What does our science, so sublime compared with the frailty of our means, so contemptible in the face of the boundless spaces of the unknown, what does our science know of absolute reality? Nothing. The world interests us only because of the ideas which we form of it. Remove the idea and everything becomes sterile, chaos, empty nothingness. An omnium-gatherum of facts is not knowledge, but at most a cold catalogue which we must thaw and quicken at the fire of the mind; we must introduce thought and the light of reason; we must interpret.

Let us adopt this course to explain the work of the Sacred Beetle. Perhaps we shall end by attributing our own logic to the insect. After all, it will be just as remarkable to see a wonderful agreement prevail between that which reason dictates to us and that which instinct dictates to the animal.

A grave danger threatens the Sacred Beetle in its grub state : the drying-up of the food. The crypt in which 
the larval life is spent has a layer of earth, some third of an inch thick, for a ceiling. Of what avail is this slender screen against the canicular heat that burns the soil, baking it like a brick to a far greater depth ? The grub's abode at such times acquires a scorching temperature; when I thrust my hand into it, I feel the moist heat of a Turkish bath.

The provisions, therefore, even though they have to last but three or four weeks, are exposed to the risk of drying up before that time and becoming uneatable. When, instead of the tender bread of the start, the unhappy worm finds no food for its teeth but a repulsive crust, hard as a pebble and unassailable, it is bound to perish of hunger. And it does, in fact, so perish. I have found numbers of these victims of the August sun who, after eating plentifully of the fresh victuals and digging themselves a cell, had succumbed, unable to continue biting into fare too hard for their teeth. There remained a thick shell, a sort of closed oven, in which the poor wight lay baked and shrivelled up.

While the worm dies of hunger in the shell turned to stone by desiccation, the full-grown insect that has finished its transformations dics there too, for it is incapable of bursting the enclosure and freeing itself. I shall return later to the final delivery and will linger no more on this point. Let us occupy ourselves solely with the woes of the worm.

The drying-up of the victuals is, we say, fatal to it. This is proved by the grubs found baked in their oven; it is also proved, in a more precise fashion, by the following experiment. In July, the period of active nidification, I place in wooden or cardboard boxes a dozen pears dug up, that morning, from the native spot. Theso 
loxes, earefully elosed, are put away in the dark, in my study, where the same temperature reigns as outside. Well, in none of them is the infant reared : sometimes the egg shrivels; sometimes the worm is hatehed, but very soon dies. On the other hand, in tin boxes or glass receptacles, things go very well: not one attempt at rearing fails.

Whence do these differences arise? Simply from this : in the high temperature of July, evaporation proceeds apace under the pervious wooden or eardboard screen; the alimentary pear dries up and the poor worm dies of hunger. In the impermeable tin boxes, in the earefullysealed glass receptaeles, evaporation does not take place, the provisions retain their softness and the grubs thrive as well as in their native burrow.

The insect employs two methods to ward off the danger of desiceation. In the first place, it compresses the outer layer with all the strength of its wide armlets, turning it into a protecting rind more homogeneous and more compact than the central mass. If I smash one of these well-dried boxes of preserves, the rind usually breaks off sharp and leaves the kernel in the middle bare. The whole suggests the shell and the almond of a filbert. The pressure exercised by the mother when manipulating her pear has influeneed the surface layer to a depth of a few millimetres and from this results the rind; further down, the pressure has not spread, whence proceeds the eentral kernel. In the hot summer months, my housekeeper puts her bread into a closed pan, to kcep it fresh. This is what the insect does, in its fashion : by dint of eompression, it confines the bread of the family in a pan.

The Saered Beetle goes further still : she beeomes a geometrician capable of solving a fine problem of mini- 
mum values. All other conditions remaining equal, the evaporation is obviously in proportion to the extent of the evaporating surface. The alimentary mass must therefore be given the smallest possible surface, in order by so much to decrease the waste of moist ure ; nevertheless, this smallest surface must unite the largest aggregate of nutritive materials, so that the worm may find sufficient nourishment. Now which is the form that encloses the greatest bulk within the smallest superficial area? Geometry answers, the sphere.

The Scarab, therefore, shapes the worm's allowance into a sphere (we will pass over the neck of the pear for the moment) ; and this round form is not the result of blind mechanical conditions, imposing an inevitable shape upon the workman; it is not the forcible effect of a rolling along the ground. We have already seen that, with the object of easier and swifter transit, the insect kneads the plunder which it intends to consume at a distance into an exact ball, without moving it from the spot at which it lies; in a word, we have observed that the round form precedes the rolling.

In the same way, it will be shown presently that the pear destined for the worm is fashioned down in the burrow. It undergoes no process of rolling, it is not even moved. The Scarab gives it the requisite outline exactly as a modelling artist would do, shaping his clay under the pressure of the thumb.

Supplied with the tools which it possesses, the insect would be capable of obtaining other forms of a less dainty curve than its pear-shaped work. It could, for instance, make the coarse cylinder, the sausage in use among the Geotrupes; simplifying the work to the utmost, it could leave the morsel without any settled form, just as it 
happened to find it. Things would proceed all the faster and would leave more time for playing in the sun. But no: the Scarab adopts exclusively the sphere, so difficult in its precision; she acts as though she knew the laws of evaporation and geometry from $\mathrm{A}$ to $\mathrm{Z}$.

It remains for us to examine the nock of the pear. What can be its object, its use ? The reply forces itself upon us irresistibly. This neck contains the egg, in the hatching-chamber. Now every germ, whether of plant or animal, needs air, the primary stimulus of life. To admit that vivifying combustible, the air, the shell of a bird's egg is riddled with an endless number of pores. The pear of the Sacred Beetle may be compared with the egg of the hen. Its shell is the rind, hardened by pressure, with a view to avoiding untimely desiccation; its nutritive mass, its meat, its yolk is the soft ball sheltered under the rind ; its air-chamber is the terminal space, the cavity in the neck, where the air envelopes the germ on every side. Where would that germ be better off, for breathing, than in its hatching-chamber projecting into the atmosphere and giving free play to the interchange of gases through its thin and easily penetrable wall and especially through the felt of scrapings that finishes the nipple?

In the centre of the mass, on the other hand, aeration is not so easy. The hardened rind does not possess the eggshell's pores; and the central kernel is formed of compact matter. The air enters it, nevertheless, for presently the worm will be able to live in it, the worm, a robust organism less difficult and nice than the first throbs of life.

These conditions, air and warmth, are so fundamental that no Dung-beetle neglects them. The nutritive hoards 
vary in form, as we shall have occasion to perceive: in addition to the pear, such shapes as the cylinder, the ovoid, the pill and the thimble are adopted, according to the species of the manipulator ; but, amid this diversity of outline, one feature of the first importance remains constant, which is the egg lodged in a hatching-chamber close to the surface, providing an excellent means for the easy access of air and warmth. And the most gifted in this delicate art is the Sacred Beetle with her pear.

I was urging just now that this first of Dung-kneaders behaved with a logic that rivals our own. At the point to which we have come, the proof of my statement is established. Nay, better still. Let us submit the following problem to our leading scientific lights : a germ is accompanied by a mass of victuals liable soon to be rendered useless by desiccation. How should the alimentary mass be shaped? Where should the egg be laid so as to be easily influenced by air and warmth?

The first question of the problem has already been answered. Knowing that evaporation is in proportion to the extent of the evaporating surface, science declares that the victuals shall be arranged in a ball, bccause the spherical form is that which encloses the greatest amount of material within the smallest surface. As for the egg, since it requires a protecting sheath to avoid any harmful contact, it shall be contained within a thin, cylindrical case; and this case shall be implanted on the sphere.

Thus the requisite conditions are fulfilled: the provisions, gathered into a ball, keep fresh; the egg, protected by its slender, cylindrical sheath, receives the influcnce of air and warmth without impediment. The 
strictly needful has been obtained; but it is very ugly. The practical has not troubled about the beautiful.

An artist corrects the brute work of reason. He replaces the eylinder by a semi-ellipsoid, of a much prettier form; he joins this ellipsoid to the sphere by means of a graceful curved surface; and the whole becomes the pear, the necked gourd. It is now a work of art, a thing of beauty.

The Scarab does exactly what the laws of rsthetics dictate to ourselves. Can she, too, have a sense of beauty? Is she able to appreciate the elegance of her pear? Certainly, she does not see it: she manipulates it in profound darkness. But she touches it. A poor touch hers, rudely clad in horn, yet not insensible, after all, to nicely-drawn outlines! 


\section{CHAPTER III}

THE SACRED BEETLE : THE MODELLING

How does the Scarab obtain the maternal pear? It is certain, to begin with, that this is in no wise shaped by the mechanism of conveyance along the ground: the shape is incompatible with a rolling in every direction, at haphazard. We might accept that for the belly of the gourd ; but the neck, the ellipsoid nipple, hollowed into a hatching-chamber! This delicate work could never result from violent, unmeasured jerks. The goldsmith's jewel is not hammered on the blacksmith's anvil. Together with other reasons, all good in evidence, already quoted, the pear-shaped outline delivers us, I hope, once and for all, from the antiquated belief that placed the egg inside a roughly-jolted ball.

To produce his masterpiece, the sculptor retires to his den. Even so the Sacred Beetle. She shuts herself down in her crypt, to model, in contemplative seclusion, the materials introduced. Two opportunities offer for obtaining the block to be worked. In the one case, the Scarab gathers from the heap, according to the method which we know, a choice block, which is kneaded into a ball on the spot and which is already spherical before it is set in motion. Were it only a question of provisions intended for her own meals, she would never act otherwise. 
When she thinks the ball of sufficient bulk, if the place do not suit her wherein to dig the burrow, she sets out with her rolling burden, walking at random till she lights upon a favourable spot. During the journey, the ball, without improving upon the perfect sphere which it was at the start, hardens a little on the surface and becomes encrusted with earth and little grains of sand. This earthy rind, picked up on the road, is an authentic sign of a more or less long excursion. The detail is not without importance; it will serve us presently.

Less frequently, the spot close to the heap whence the block has been extracted satisfies the insect as suitable for the excavation of the burrow. The soil is free from pebbles and easy to dig. Here, no journey is necessary, nor, therefore, any ball convenient for transit. The soft biscuit of the sheep is gathered and stored as found and enters the workshop a shapeless mass, either in one piece, or, if need be, in different lumps.

This case occurs seldom in the natural state, because of the coarseness of the ground, which abounds with broken stones. Sites practicable for easy digging are few and far between and the insect has to roam about, with its burden, to find them. In my voleries, on the other hand, where the earthy layer has been purged with the sieve, it is the usual case. Here the earth is easy to dig at any point; wherefore the mother, working for her laying, is content to lower the nearest morsel underground, without giving it any definite shape.

Whether the storing without preliminary ball or conveyance be achieved in the fields or in my voleries, the final result is most striking. One day, I see a shapeless lump disappear into the crypt. The next day, or the day after, I visit the workshop and find the artist face 
to face with her work. The uncouth mass of the start, the loose shreds introduced by armfuls have become a pear of perfect accuracy and conscientious finish.

The artistic object bears the marks of its method of manufacture. The part that rests upon the bottom of the cavity is crusted over with earthy particles; all the rest is of a glossy polish. Owing to its weight, owing also to the pressure exercised when the Scarab manipulates it, the pear, which is still quite soft, has become soiled with grains of earth on the side that touches the floor of the workshop; on the remainder, which is the larger part, it retains the delicate finish which the insect was able to give it.

The inferences to be drawn from these minutelyobserved details are obvious: the pear is no turner's work; it has not been obtained by any sort of rolling on the ground of the spacious studio, for then it would have been soiled with earth all over. Besides, its projecting neck precludes this mode of fabrication. It has not even been turned from one side to the other, as is loudly proclaimed by its unblemished upper surface. The Scarab, therefore, has moulded it where it lies, without turning or shifting it in any way; she has modelled it with little taps of her broad battledores, just as when we saw her model her ball in the daylight.

Let us now return to the usual case, in the open. The materials then come from a distance and are introduced into the burrow in the form of a ball covered with soil on every part of its surface. What will the insect do with this sphere which contains the paunch of the future pear ready-made? The answer would present no serious difficulty if, limiting my ambition to the results obtained, I sacrificed the means employed. It would be 
enough for me, as I have often done, to eapture the mother in her burrow with her ball and earry one and all home, to my animal laboratory, to watch events at first hand.

A large glass jar is filled with earth, sifted, moistened and heaped to the desired depth. I place the mother and her beloved pill, which she holds embraced, on the surface of this artificial soil. I stow away the apparatus in a half-light and wait. My patience is not very long tried. Urged by the labour of the ovaries, the insect resumes its interrupted work.

In eertain cases, I see it, still on the surface, destroying its ball, ripping it up, eutting it to pieces, shredding it. This is not in the least the act of one in despair who, finding herself a captive, breaks the cherished object in her bewilderment. It is an act of wise hygienies. A scrupulous inspection of the morsel gathered in haste, among lawless competitors, is often necessary, for supervision is not always easy on the harvesting-spot itself, in the midst of thieves and robbers. The ball may eontain a blend of little Onthophagi, of Aphodians, which have not been noticed in the heat of acquisition.

These involuntary intruders, finding themselves very comfortable in the heart of the mass, would themselves make good use of the contemplated pear, much to the detriment of the legitimate consumer. The ball must be purged of this starveling brood. The mother, therefore, destroys it, reduces it to atoms, scrutinizes it. Then, out of the collected remnants, the ball is remade, stripped of its earthy rind. It is dragged underground and becomes an immaculate pear, always excepting the surface touching the soil.

Oftener still, the ball is thrust by the mother into the 


\section{6}

\section{THE LIFE AND LOVE OF THE INSECT}

oarth of the jar just as I took it from the burrow, with the wrinkled covering which it acquired in rolling across country during the journey from the place where it was found to the spot where the insect intended to use it. In that case, I find it at the bottom of my jar converted into a pear, itself wrinkled and encrusted with earth and sand over the whole of its surface, thus proving that the pear-shaped outline has not demanded a general reeasting of the mass, inside as well as out, but has been obtained by simple pressure and by drawing out the neck.

This is how, in the vast majority of cases, things happen in the normal state. Almost all the pears which I dig up in the fields are erusted, unpolished, some more, others less. If we put on one side the inevitable encrustations due to the carting across fields, these blemishes would seem to point to a prolonged rolling in the interior of the subterranean manor. The few which I find perfectly smooth, especially those wonderfully neat specimens furnished by my voleries, dispel this mistake entirely. They show us that, with materials collected near at hand and stored away unshaped, the pear is modelled wholly without rolling; they prove to us that, where the others are concerned, the earthy wrinkles of the rind are not the signs of a rolling manipulation at the bottom of the workshop, but simply the marks of a fairly long journey on the surface of the ground.

To be present at the construction of the pear is no easy matter: the sombre artist obstinately refuses to do any work as soon as the light reaches her. She needs absolute darkness for her modelling; and I need light if I would see her at work. It is impossible to unito the two conditions. Let us try, nevertheless; lot us seizo by fragments the truth which hides itself in its fulness. 


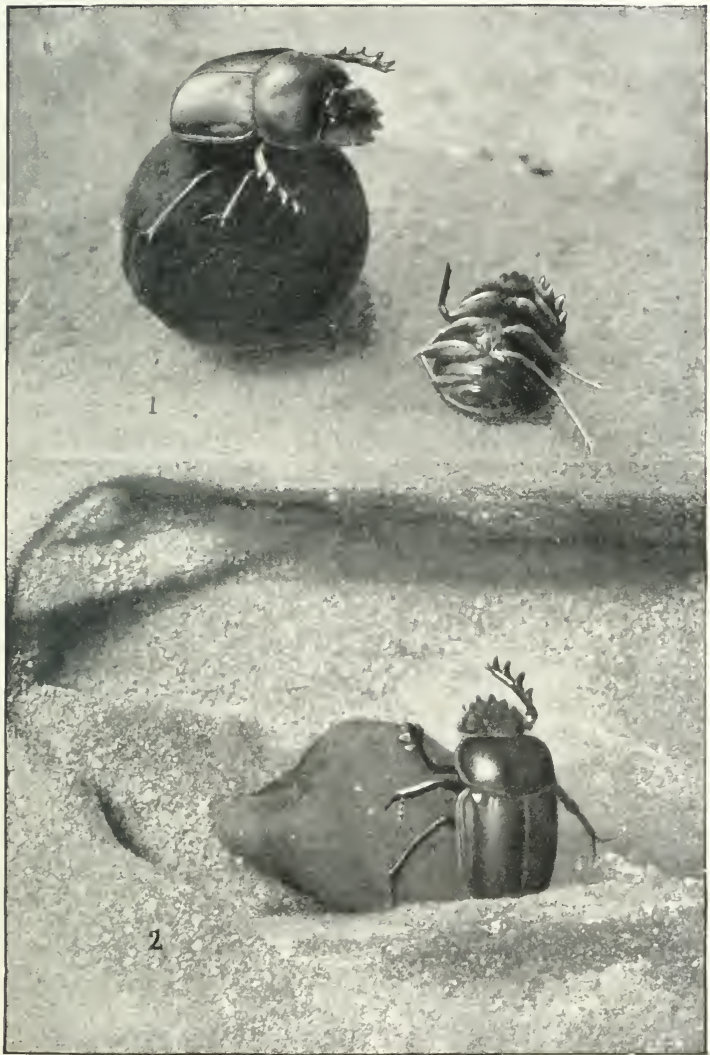

1. The Sacred Beetle pushing away and overturning a thieving friend who tries to force his assistance upon him.

2. Crypt in which the Beetle shapes a grub's provision into a pear. 

The arrangements made are as follows: I onee more take the large glass jar. I cover the bottom with a layer of earth a fow inches in thickness. To obtain the transparent workshop necessary for my observations, I fix a tripod on the earthy layer and, on this support, a decimetre ${ }^{1}$ high, I place a round deal slab of the same diameter as the jar. The glass-walled ehamber thus marked out will represent the roomy crypt in which the insoct works. In the edge of the deal slab, a hollow is eut, large enough to permit of the passage of the Sacred Beetle and her ball. Lastly, above this screen, I heap a layer of earth as deep as the jar allows.

During the operation, a portion of the upper earth falls through the opening and slips down to the lower space in a wide inclined plane. This was a circumstance which I had foreseen and which was indispensable to my plan. By means of this slope, the artist, when she has found the eommunicating trap-door, will make for the transparent den which I havo arranged for her. She will make for it, of eourse, only provided that she be in perfect darkness. I therefore eontrive a eardboard eylinder, closed at the top, and place the glass apparatus inside it. Left standing where it is, the opaque sheath will provide the dusk which the Scarab demands; suddenly raised, it will give the light which I require on my side.

Things being thus arranged, I go in search of a mother lately romoved from her natural lodging with her ball. A morning is enough to provide me with what I noed. I place the mother and her ball on the surface of the upper layer of earth; I eap the apparatus with its cardboard sheath; and I wait. The insoct, stubborn at 13.9 inches.-Translator's Note. 
its work so long as the egg is not deposited, will dig itsolf a now burrow, dragging its ball with it as it goes; it will pass through the upper layer of earth, which is not sufficiently thick; it will come upon the deal board, an obstacle similar to the broken stones that often bar its passage in the eourse of its normal oxcavations ; it will investigate the cause of the impediment and, finding the opening, will descend through this trap-door to the lower compartment, which, being free and roomy, will represent to tho insect the erypt whence I have just removed it. Thus prophesies my foresight. But all this takes time; and I must wait for the morrow to satisfy my impatient curiosity.

The hour has como: let us go and see. The studydoor was left open yesterday: the mere sound of the door-handle might stop my distrustful worker. By way of greater precaution, before entering, I put on silent slippers. And - whoosh! The eylinder is removed. Capital! My expectations aro fully justified.

The Scarab oeeupies the glazed workshop. I eatch her at work, with her broad foot laid on the rough sketeh of the pear. But, startled by the sudden light, she remains motionless, as though petrified. This lasts a fow seeonds. Then she turns her back upon me and awkwardly ascends the inclined plane, to reach the darkling heights of her gallery. I give a glance at tho work, take note of its shape, its position and its aspect, and restore darknoss with the eardboard sheath. Let us not prolong the indiscretion, if we would renew the test.

My sudden, brief visit gives us a first insight into the mysterious work. The ball, at first exactly spherieal, now has a stout pad circumseribing a sort of shallow 
crater. The work reminds me, in greatly reduced proportions, of certain prehistoric pots, with round bellies, thick lips around the mouth and a neck strangled by a narrow groove. This rude outline of a pear tells us of the insect's method, a method identical with that of Pleistoscene man ignorant of the potter's wheel.

The plastic ball, girt with a circle at one end, has been hollowed out in a groove, the starting-point of the neck; it has, moreover, been drawn out a little into an obtuse projection. In the eentre of this projection. a pressure has been effected, which, causing the matter to fall back over the edges, has produced the crater, with its shapeless lips. Circular enlacement and pressure have sufficed for this first part of the work.

Towards evening, I pay a fresh sudden visit, amid complete silence. The insect has recovered from its excitement of the morning and gone down again to its workshop. Flooded

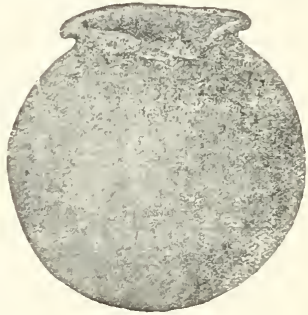

Fig. 2.-The Sacred Beetle's pill dug out cupwise to receive the egg. with light and baffled by the strange events to which my artifices give rise, it at once makes off and takes refuge in the upper storey. The poor mother, persecuted by my illuminations, runs up into the thick of the darkness, but regretfully, with hesitating strides.

The work has progressed. The crater has become deeper; the thick lips have disappeared, are thinner, closer together, drawn out into the neck of a pear. The object, however, has not changed its place. Its position, its aspect are exactly as I noted them before. The 
side that lay on the ground is still at the bottom, at the same point; the side that faced upwards is still at the top; the crater that lay on my right has been replaced by the neck, still on my right. Whence comes a conclusion completely confirming my previous statements: no rolling; mere pressure, which kneads and moulds.

The next day, a third visit. The pear is finished. Its neck, yesterday a yawning sack, is now closed. The egg, therefore, is laid; the work has been carried through and demands only the finishing touches of general polishing, touches upon which the mother, so intent on geometrical perfection, was cloubtless engaged at the time when I disturbed her.

The most delicate part of the affair escapes my observation. I see quite clearly, in the main, how the hatching-chamber of the egg is obtained : the thick pad surrounding the original crater is thinned and flattened out under the pressure of the feet and lengthened into a sack the mouth of which gradually narrows. Up to this point, the work provides its own explanation. But we have no explanation of the exquisite perfection of the cell wherein the egg is to hatch, when we think of the insect's rigid tools, the wide, toothed armlets whose jerky awkwardness suggests the spasmodic movements of an automaton.

With this clumsy equipment, excellently adapted to coarse work though it be, how does the Scarab obtain the natal dwelling, the oval nest so daintily polished and glazed within? Does the foot, a regular saw, fitted with enormous teeth, begin to rival the painter's brush in delicacy from the moment when it is inserted through the narrow orifice of the sack? Why not? I have said elsewhere and this is the occasion to repeat it: 
the tool does not make the workman. The insect exerts its gifts as a specialist with any kind of tool wherewith it is supplied. It can saw with a plane or plane with a saw, like the model workman of whom Franklin tells us. The same strong-toothed rake with which the Sacred Beetle rips the earth is used by her as a trowel and brush wherewith to glaze the stucco of the chamber in which the grub will be born.

In conclusion, one more detail concerning this hatchingchamber. At the extreme end of the neck of the pear, one point is always pretty clearly distinguished: it bristles with stringy fibres, while the rest of the neck is carefully polished. This is the plug with which the mother has closed the narrow opening after placing the egg; and this plug, as its hairy structure shows, has not been subjected to the pressure which, throughout the rest of the work, crams the smallest projecting scrap into the mass and causes it to disappear.

Why this arrangement at the extreme pole, a very curious exception, when every elsewhere the pear has received the powerful blows of the insect's foot? The hind-end of the egg rests against this plug, which, were it pressed down and driven in, would transmit the pressure to the germ and imperil its safety. The mother, aware of the risk, blocks up the hole without ramming the stopper: the air in the hatching-chamber is thus more easily renewed; and the egg escapes the dangerous concussion of the compressing paddle. 


\section{CHAPTER IV}

THE SACRED BEETLE: THE GRUB, THE METAMORPHOSIS, THE HATCHING-CHAMBER

THE hatching-chamber is an oval recess about one centimetre $^{1}$ in diameter. The egg is fixed at the bottom of this recess. It is cylindrical in shape, rounded at both ends, yellowish-white in colour and having nearly the bulk of a grain of wheat, but shorter. The inner wall of the recess is plastered with a greenish-brown matter, shiny, half-fluid, a real cream destined to form the first mouthfuls of the grub. In order to produce this delicate fare, does the mother select the quintessence of the ordure? The appearance of the mess tells me differently and assures me that it is a broth elaborated in the maternal stomach. The Pigeon softens the corn in her crop and turns it into a sort of milk-diet which she afterwards disgorges for her brood. The Dung-beetle has the same fond ways: she half-digests selected viands and disgorges them as a fine pap, with which she hangs the walls of the nest wherein her egg is laid. In this manner, the grub, when hatched, finds an easily-digested food that soon strengthens its stomach and allows it to attack the underlying layers, which are less daintily prepared.

A progressive change of diet is here made manifest. On leaving the egg, the feeble little grub licks the fine 1 '39 inch.-Translator's Note. 
sop on the walls of its lodging. There is not much of it, but it is strengthening and possesses a high nourishing value. The pap of tender childhood is followed by the pottage of the weaned nursling.

The time has come for a sight stranger than any yet displayed to me by the mechanical daring of the insect. Anxious to observe the grub in the intimacy of its home, I open in the belly of the pear a little peep-hole half a centimetre square. The head of the recluse at once appears in the opening, to enquire what is happening. The breach is perceived. The head disappears. I can just see the white chine turning about in the narrow cabin; and, then and there, the window which I have contrived is closed with a soft, brown paste, which soon hardens.

The inside of the cabin, said I to myself, is no doubt a semi-fluid porridge. Turning upon itself, as is shown by the sudden slide of the back, the grub has collected an armful of this material and, completing the circuit, has stuck its load, by way of mortar, in the breach considered dangerous. I remove the closing plug. The grub acts as before, puts its head at the window, withdraws it, spins round upon itself like a fruit-stone slipping in its shell and forthwith produces a second plug as ample as the first. Forewarned of what was coming, this time I saw more clearly.

What a mistake was mine! I am not too greatly thunderstruck, however : in the exercise of its defensive skill, the animal often employs methods which our imagination would not dare to contemplate. It is not the head that is presented at the breach, after the preliminary twisting: it is the opposite extremity. The grub does not bring an armful of its alimentary dough, 
gathered by scraping the walls: it excretes upon the aperture to be closed; a much more economical proceeding. Sparingly measured out, the rations must not be wasted : there is just enough to live upon. Besides, the cement is of better quality; it soon sets. Lastly, the urgent repairs are more quickly effected, if the intestines lend their kindly aid.

They do, in point of fact, and to an astonishing degree. Five, six times in succession and oftener, I remove the fixed plug; and, time after time, the mortar discharges a copious ejaculation from its apparently inexhaustible reservoir, which is ever at the mason's service, without an interval for rest. The grub is already beginning to resemble the Sacred Beetle, whose stercoral prowess we know : it is a past master in the art of dunging. It possesses above any other animal in the world an intestinal deftness which anatomy will undertake to explain to us, partly, later on.

The plasterer and the mason have their trowels. In the same way, the grub, that zealous repairer of breaches made in its home, has a trowel of its own. The last segment is lopped off slantwise, and carries on its dorsal surface a sort of inclined plane, a broad disk surrounded by a fleshy pad. In the middle of the disk is a gash, forming the cementing-aperture. Behold the fair-sized trowel, flattened out and supplied with a rim to prevent the compressed matter from flowing away in useless waste.

As soon as the plastic gush is laid down in a lump, the levelling and compressing instrument sets to work to introduce the cement well into the irregularities of the breach, to push it right through the thickness of the ruined portion, to give it consistency, to level it. After this 
stroke of the trowel, the grub turns round: it comes and bangs and pushes the work with its wide forehead and improves it with the tip of its mandibles. Wait a quarter of an hour and the repaired portion will be as firm as the rest of the shell, so quickly does the cement set. Outside, the repairs are betrayed by the rough prominence of the material forced outwards, which remains inaccessible to the trowel; but, inside, there is no trace of the breakage: the usual polish has been restored at the injured spot. A plasterer stopping a holc in a wall in our rooms could produce no better piece of work.

Nor do the worm's talents end here. With its cement, it becomes a mender of pots and pans. Let me explain. I have compared the outside of the pear, which, when pressed and dried, becomes a strong shell, with a jar containing fresh food. In the course of my excavations, sometimes made on difficult soil, I have happened oceasionally to break this jar with an ill-directed blow of the trowel. I have collected the potsherds, pieced them together, after restoring the worm to its place, and kept the whole thing in one by wrapping it in a bit of old newspaper.

On reaching home, I have found the pear put out of shape, no doubt, and scamed with scars, but just as solid as ever. During the walk, the grub had restored its ruined dwelling to condition. Cement injected into the cracks joined the pieces together ; inside, a thick plastering strengthened the inner wall, so much so that the repaired shell was quite as good as the untouched shell, but for the irregularity of the outside. In its artisticallymended stronghold, the worm found the peace essential to its existence. 
Let us now give a brief description of the grub, without stopping to cnumerate the articulations of the palpi and antennæ, irksome details of no immediate interest. It is a fat worm and has a fine, white skin, with pale slate-coloured reflections proceeding from the digestive organs, which are visible transparently. Bent into a broken arch or hook, it is not unlike the grub of the Cockchafer, but has a much more ungainly figure, for, on its back, at the sudden bend of the look, the third, fourth and fifth segments of the abdomen swell into

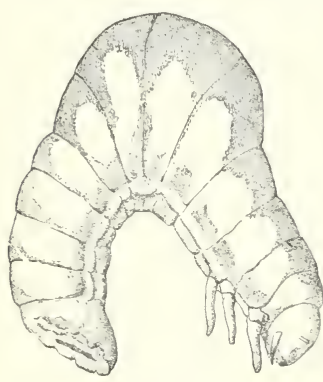

Fig. 3.- Grub of the Sacred Beetle. an enormous protuberance, a tumour, a pouch so prominent that the skin seems on the point of bursting under the pressure of the contents. This is the animal's most striking feature : the fact that it carries a wallet.

The head is small in proportion to the size of the grub, slightly convex and bright red, studded with a few pale bristles. The legs are fairly long and sturdy, ending in a pointed tarsus. The grub does not use them as limbs of progression. Taken from its shell and placed upon the table, it struggles in clumsy contortions without succeding in shifting its position; and the cripple betrays its anxiety by repeated eruptions of its mortar.

Let us also mention the terminal trowel, the last segment lopped into a slanting disk and rimmed with a fleshy pad. In the centre of this inclined plane is the open stexcoral gash, which thus, by a very unusual inversion, 
occupies the upper surface. An enormous hump and a trowel : that gives you the animal in two words.

We must not finish the history of the grub without saying a few words on its internal structure. Anatomy will show us the works wherein the cement employed in so original a manner is manufactured. The stomach or chylific ventricle is a long, thick cylinder, starting from the creature's neck after a very short gullet. It measures about three times the length of the animal. In its last quarter, it carries a voluminous lateral pouch distended by the food. This is a subsidiary stomach in which the supplies are stored so as to yield their nutritive principles more thoroughly. The chylific ventricle is much too long to lie straight in the grub's bowels and bends back upon itself, in front of its appendix, in the form of a large loop occupying the dorsal surface. It is to contain this loop and the lateral pouch that

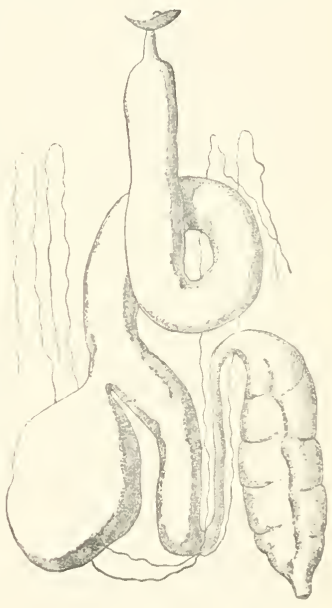

Fia. 4--Digestive apparatus of the Sacred Beetle. the back is swollen into a protuberance. The grub's wallet is, therefore, a second paunch, an annexe, as it were, of the stomach, which is itself incapable of holding the voluminous digestive apparatus. Four very fine, very long tubulures, irregularly entwined, four Malpighian vessels mark the limits of the chylific ventricle. 
Next comes the intestine, narrow, cylindrical, rising forwards. The intestine is followed by the rectum, which pushes backwards. This latter, which is of exeeptional size and fitted with powerful walls, is wrinkled across, bloated and distended by its contents. Here is the roomy warehouse in which the scoriæ of the digestion accumulate; here is the mighty ejaculator, always ready to provide cement.

The grub gets bigger as it eats the wall of its house from the inside. Little by little, the belly of the pear is scooped out into a cell whose capacity grows in proportion to the growth of the inhabitant. Ensconced in its hermitage, furnished with board and lodging, the recluse waxes stout and fat. What more does it want?

In four or five weeks, the complete development is obtained. The apartment is ready. The worm sheds its slin and becomes a chrysalis. There are very few in the entomological world to vie in sober beauty with the tender creature which, with its wing-cases laid in front of it like a wide-creased scarf and its fore-legs folded under its head, as when the full-grown Scarab counterfeits death, suggests the idea of a mummy maintained by its bandages in a sacerdotal pose. Semi-translucent and honey-yellow, it looks as though it were cut from a block of amber. Imagine it hardened in this state, mineralized, made incorruptible : it would be a splendid topaz jewel.

In this marvel, so severe and dignified in shape and colouring, one point above all captivates me and gives me at last the solution of a far-reaching problem. Are the front-legs furnished with a tarsus, yes or no? This is the great business that makes me forget the jewel for the sake of a struetural detail. Let us then return to a subject that exeited me in my early days; for the answer 
has come at last, late, it is true, but certain and indisputable.

By a very strange exception, the full-grown Sacred Beetle and his congeners are without front tarsi ; they lack on their fore-legs that five-jointed finger which is the rule among the highest division of Coleoptera, the Pentamera. The other limbs, on the contrary, follow the common law and possess a very well-shaped tarsus. Is the formation of the toothed armlets original or aceidental ?

At first sight, an accident seems probable enough. The Searab is a strenuous miner and a great pedestrian. Always in contact with the rough soil, whether in walking or digging; used, moreover, for constant leverage when the inseet is rolling its ball backwards, the fore-legs are much more exposed than the others to the danger of spraining and twisting their delieate finger, of putting it out of joint, of losing it entirely, from the very first moment when the work begins.

Lest this explanation should appeal to any of my readers, I will hasten to undeceive them. The absenee of the front fingers is not the result of an accident. 'The proof of what I say lies here, under my eyes, without the possibility of a rejoinder. I examine the nymph's legs with the magnifying-glass: those in front have not the least vestige of a tarsus; the toothed limb ends bluntly, without a trace of a terminal appendage. In the others, on the contrary, the tarsus is as distinct as possible, notwithstanding the shapeless, gnarled condition due to the swaddling-bands and the humours of the chrysalis state. It suggests a finger swollen with chilblains.

If the evidence of the nymph were not sufficient, there 
would be that of the perfect insect which, casting its rejected mummy-clothes and moving for the first time in its shell, wields fingerless armlets. The fact, thereforc, is established for certain : the Sacred Beetle is born maimed; his mutilation dates from his birth.

"Very well," reply our fashionable theorists, "theSacred Beetle is mutilated from the start; but his remote ancestors were not. They were formed according to the general rule, they were correct in structure down to this slight digital detail. There were some who, in the course of their rude task as diggers and rollers, wore out that delicate, cumbrous, useless member; and, finding themselves better equipped for their work by this accidental amputation, they bequeathed it to their successors, to the great benefit of the race. The present insect profits by the improvement obtained by a long array of ancestors, and, acting under the stimulus of vital competition, gives permanence to an advantageous condition due to chance."

$O$ ingenuous theorists, so triumphant on paper, so vain in the face of reality, listen to me for yet one moment more! If the loss of the front fingers be a fortunate thing for the Sacred Beetle, who faithfully hands down the leg of yore fortuitously maimed, why should it not be so with the other members, if they too happened to lose by chance their terminal appendage, a small, powerless filament, almost utterly unserviceable, and, owing to its delicacy, a cause of grievous conflicts with the roughness of the soil ?

The Sacred Beetle is not a climber, but an ordinary pedestrian, supporting himself upon the point of an ironshod stick, by which I mean the stout spine or prickle whercwith the tip of the leg is armed. He does not have to hold on by his claws to some hanging branch, as does 
the Cockchafer. And it would therefore, meseems, be entirely to his advantage to rid himself of the four remaining fingers, projecting sideways, idle on the march, inactive in the construction and carriage of the ball. Yes, that would mean progress, for the simple reason that the less hold one gives to the enemy the better. It remains to be seen if chance ever produces this state of things.

It does and very often. At the end of the fine season, in October, when the insect has worn itself out in digging, in carrying balls and in modelling pears, the maimed, the victims of work, form the great majority. I sce them, both in my voleries and outside, displaying every degree of amputation. Some have lost the finger on their four hind-legs altogether; others retain a stump, a couple of joints, a single joint; those which are least damaged have a few members left intact.

This is certainly the mutilation pleaded by the theorists. And it is no accident, occurring at long intervals : every year, the cripples outnumber the others at the time when the winter-season is at hand. In their final labours, they seem no more embarrassed than those who have been spared by the trials of life. On both sides, I find the same quickness of movement, the same dexterity in kneading the ammunition-bread which will enable them to bear the first rigours of winter philosophically underground. In the scavenger's work, the maimed vie with the others.

And these cripples form a race; they spend the bad season underground; they wake up in the spring, return to the surface and take part, for a second, sometimes even for a third time, in life's great festival. Their descendants ought to profit by an improvement which 
has been renewed year by year, ever since Scarabs came into the world, and which has certainly had time to become fixed and to convert itself into a settled habit. But they do nothing of the sort. Every Sacred Beetle that breaks his shell, with not one exception, is endowed with the four tarsi prescribed by rule.

Well, theorists, what say you to that? For the two front legs, you offer a sort of an explanation; and the four others contradict you flatly. Have you not been taking fancy for truth?

Then what is the cause of the original mutilation of the Scarab? I will confess plainly that I know nothing at all about it. Nevertheless, those two maimed members are very strange: so strange, in the endless order of insects, that they have exposed the masters, the greatest masters, to lamentable blunders. Let us listen first to Latreille, ${ }^{1}$ the prince of descriptive entomologists. In his account of the insects which ancient Egypt painted or carved upon her monuments, ${ }^{2}$ he quotes the writings of Horapollo, an unique document which has been preserved for us in the papyri for the glorification of the sacred insect :

"One would feel tempted at first," he says, "to set down as fiction what Horapollo says of the number of that Scarab's fingers. According to him, there are thirty. Nevertheless, this computation, judged by the way in which he looks at the tarsus, is perfectly correct, for this part consists of five joints ; and, if we take each of them for a finger, the legs being six in number and each ending

1 Pierre André Latreille (1762-1833), one of the founders of entomological science.-Translator's Note.

${ }_{2}^{2}$ Mémoires du Muséum d'histoire naturelle, vol. v., p. 219.Author's Note. 
in a five-jointed tarsus, the Sacred Beetles obviously have thirty fingers."

Forgive me, illustrious master: the total number of joints is but twenty, because the two front legs are devoid of tarsi. You have been carried away by the general law. Losing sight of the singular exception, which was certainly known to you, you said thirty, swayed for a moment by that overwhelmingly positive law. Yes, the exception was known to you, so much so that the figure of the Sacred Beetle accompanying your account, a figure drawn from the insect and not from the Egyptian monuments, is irreproachably accurate: it has no tarsi on its fore-legs. The blunder is excusable, in view of the strangeness of the exception.

What did Horapollo himself see? Apparently what we see in our day. If Latreille's explanation be right, as everything secms to denote, if the Egyptian author began by counting thirty fingers according to the number of joints in the tarsi, it is because his enumeration was based in his mind upon the facts of the general situation. He was guilty of a mistake which was not very reprehensible, seeing that, some thousand years later, masters like Latreille and Mulsant were guilky of it in their turn. The only culprit in all this business is the exceptional structure of the insect.

"But," I may be asked, "why should not Horapollo have seen the exact truth? Perhaps the Scarab of his century had tarsi which the insect does not possess today. In that ease, it has been altered by the patient work of time."

Before answering this evolutionary objection, I will wait for some one to show me a natural Scarab of Hora- 
pollo's date. The hypogea which so religiously guard the cat, the ibis and the erocodile must also contain the saered inseet. All that I have at my disposal is a few figures representing the Sacred Beetle as we find him engraved on the monuments or carved in fine stone as an amulet for the mummies. The aneient artist is remarkably faithful in the execution of the whole; but his graver, his chisel have not troubled about details so insignificant as those of the tarsi.

Ill-supplied though I be with doeuments of this kind, I greatly doubt whether carving or engraving will solve the problem. Even if an image with front tarsi were diseovered somewhere or other, the question would be no further advanced. One eould always plead a mistake, earelessness, a leaning towards symmetry. The doubt, as long as it prevails in certain minds, can only be removed by the aneient inseet in a natural state. I will wait for it, convinced beforehand that the Pharaonic Scarab differed in no way from our own.

Let us not take leave of the old Egyptian author just yet, in spite of his usually incomprehensible jargon, with its senseless allegories. He sometimes has views that are strikingly correet. Is it a chance coineidenee? Or is it the result of serious observation? I should be gladly inclined to adopt the latter opinion, so perfect is the agreement between his statements and certain biologieal details of which our own seienee was ignorant until quite lately. Where the intimate life of the Scarab is concerned, Horapollo is much better-informed than ourselves.

In partieular, he writes as follows :

"The Scarab buries her ball in the ground, where she remains hidden for twenty-eight days, a space of time 
equal to that of a revolution of the moon, during which period the offspring of the Scarab quickens. On the twenty-ninth day, which the insect knows to be that of the conjunction of the sun and moon and of the birth of the world, it opens the ball and throws it into the water. From this ball issue animals that are Scarabs."

Let us dismiss the revolution of the moon, the conjunction of the sun and moon, the birth of the world and other astrological absurdities, but remember this: the twenty-eight days of incubation required by the ball underground, the twenty-eight days during which the Scarab is born to life. Let us also remember the indispensable intervention of water to bring the insect out of its burst shell. These are precise facts, falling within the domain of true science. Are they imaginary? Are they real ? The question deserves investigation.

Antiquity knew nothing of the wonders of the metamorphosis. To antiquity, a grub was a worm born of corruption. The poor creature had no future to lift it from its abject condition: as worm it appeared and as worm it had to disappear. It was not a mask under which a superior form of life was being elaborated; it was a definite entity, supremely contemptible and doomed soon to return to the rottenness that gave it birth.

To the Egyptian author, therefore, the Scarab's larva was unknown. And if, by chance, he had had before his eyes the shell of the insect inhabited by a fat, big-bellied worm, he would never have suspected in the foul and ugly animal the sober beauty of the future Scarab. According to the ideas of the time, ideas long maintained, the sacred insect had neither father nor mother: an error excusable in the midst of the simplicity of the 
ancients, for here the two sexes are outwardly indistinguishable. It was born of the ordure that formed its ball; and from its birth dated the appearance of the nymph, that anber gem displaying, in a perfectly recognizable form, the features of the full-grown insect.

In the eyes of all antiquity, the Sacred Bcetle begins to be born to life at the moment when he can be recognized, not before; else we should have the as yet unsuspected worm of affiliation. The twenty-eight days, therefore, during which, as Horapollo tells us, the offspring of the insect quickens, represent the nymphal phase. This period has been the object of special attention in my studies. It varies, but within narrow limits. The notes taken mention thirty-three days as the longest duration and twenty-one as the shortest. The average, supplied by a score of observations, is twenty-eight days. This identical number twenty-eight, this number of four weeks appears as such and oftener than the others. Horapollo spoke truly: the real insect takes life in the interval of a lunar month.

The four weeks past, behold the Scarab in his final shape: the shape, yes, but not the colouring, which is very strange when the chrysalis casts its skin. The head, legs and thorax are a dark red, except the denticulations, which are a smoky brown. The abdomen is an opaque white; the wing-cases are a transparent white, very faintly tinged with yellow. This majestic dress, combining the red of the cardinal's cassock with the white of the priest's alb, is but temporary and turns darker by degrees, to make way for a uniform of ebon black. About a month is necessary for the horny armour to acquire a firm consistency and a definite hue.

At last, the Scarab is fully matured. Awaking within 
him is the delicious restlessness of an approaching liberty. $\mathrm{He}$, hitherto the son of the darkness, foresees the gladness of the light. His longing is great to burst the shell, to emerge from below ground and come into the sun; but the difficulty of liberating himself is far from small. Will he escape from the natal cradle, now become an odious prison? Or will he not escape? It depends.

It is generally in August that the Sacred Beetle is ripe for the delivery : in August, save for rare exceptions, the most torrid, dry and scorching month of the year. Should there not then come, from time to time, a shower that to some slight extent assuages the panting earth, then the cell to be burst and the wall to be broken through defy the strength and patience of the insect, which is powerless against all that hardness. By dint of a prolonged desiccation, the soft original matter has become an insuperable rampart; it has turned into a sort of brick baked in the oven of the dog-days.

I need hardly say that I have not failed to experiment with the insect in these difficult circumstances. Pear-shaped shells are gathered containing the fullgrown Scarab, who is on the point of issuing, in view of the lateness of the season. These shells, already dry and very hard, are laid in a box where they retain their aridity. A little earlier in one case, a little later in the other, I hear the sharp grating of a rasp inside each shell. It is the prisoner working to make himself an outlet by scraping the wall with the rake of his shield and fore-feet. Two or three days elapse and the delivery seems to make no progress.

I come to the assistance of a pair of them by myself opening a loop-hole with the point of a knife. According to my idea, this first breach will help the egress of the 
recluse by offering him a place to start upon, an exit that only needs widening. But not at all : these favoured ones advance no quicker with their work than the rest.

In less than a fortnight, silence prevails in all the shells. The prisoners, worn out with ineffectual efforts, have perished. I break the caskets containing the deceased. A meagre pinch of dust, representing hardly an average pea in bulk, is all that the sturdy implements-rasp, saw, harrow and rake-have succeeded in sundering from the invincible wall.

Other shells, of a similar hardness, are wrapped in a wet rag and enclosed in a flask. When the moisture has soaked through them, I relieve them of their wrapper and keep them in the corked flask. This time, events take a very different turn. Softened to a nicety by the wet rag, the shells burst, ripped open by the shove of the prisoner, who props himself boldly on his legs, using his back as a lever; or else, scraped away at one point, they crumble to pieces and yawn with a wide breach. The success is complete. In each case, the delivery is effected without impediment; a few drops of water have brought them the joys of the sun.

For the second time, Horapollo was right. Certainly, it is not the mother, as the old author says, who throws her ball into the water: it is the clouds that provide the liberating ablution, the rain that facilitates the ultimate release. In the natural state, things must happen as in my experiments. In August, in a burnt soil, under a thin screen of earth, the shells, baked like bricks, are for most of the time as hard as pebbles. It is impossible for the insect to wear out its casket and escape from it. But, should a shower come upon the scene-that lifegiving baptism which the seed of the plant and the 
family of the Scarab alike await within the ashes of the soil-should a little rain fall, soon the fields will present the appearance of a resurrection.

The earth is soaked. This is the wet rag of my experiment. At its touch, the shell recovers the softness of its early days, the casket becomes yielding; the insect makes play with its legs, pushes with its back; it is free. It is, in fact, in the month of September, during the first rains which herald the coming autumn, that the Scarab leaves the native burrow and comes to enliven the pastoral sward, even as the former generation enlivened it in the spring. The clouds, hitherto so chary, have come at last to set him free.

Under conditions of exceptional coolness of the earth, the bursting of the shell and the emerging of its occupant can occur at an earlier period; but, in ground scorched by the fierce sun of summer, as is usually the case in these parts, the Scarab, however eager he may be to see the light, must needs wait for the first rains to soften his stubborn shell. A downpour means to him a question of life and death. Horapollo, that echo of the Egyptian magi, saw true when he made water play its part in the insect's birth.

But let us drop the jargon of antiquity and its shreds of truth; let us not neglect the first acts of the Sacred Beetle on leaving his shell; let us be present at his prentice steps in the open-air life. In August, I break the casket in which I hear the helpless prisoner fretting. The insect, the only one of its species, is placed in a volery. Provisions are fresh and plentiful. This is the moment, I say to myself, when we take refreshment after so long an abstinence. Well, I am wrong: the new recruit sets no store by the victuals, notwithstand- 
ing my invitations, my appeals to the appetizing heap. What he wants above all is the joys of light. He climbs the metal trellis, sets himself in the sun and there, motionless, takes his fill of its beams.

What passes through his dull-witted scavenger's brain during this first bath of radiant light? Probably nothing. He enjoys the unconscious happiness of a flower blooming in the sun.

At last, the insect goes to the victuals. A ball is constructed according to all the rules. There is no apprenticeship, no first attempt : the spherical form is obtained as regularly as though after long practice. A burrow is dug wherein to eat in peace the lately-kneaded bread. Here we find the novice thoroughly versed in his art. No experience, however prolonged, will add anything to his talents. 
THE SPANISH COPRIS 



\section{CHAPTEP V}

\section{THE SPANISH COPRIS}

To show instinct performing on behalf of the egg what reason, ripened by study and experience, would advise is a result of no mean philosophic import; and I find myself seized with a scruple aroused by scientific austerity. Not that I wish to give science a forbidding aspect: I am convinced that one can say excellent things without employing a barbarous vocabulary. Clearness is the supreme politeness of whoso wields a pen. I do my best to observe it. And the scruple that stops me is of another kind.

I ask myself if I am not here the victim of an illusion. I say to myself :

"The Sacred Beetles and others are manufacturers of balls, of pills. That is their trade, learnt we know not how, prescribed perhaps by their structure, in particular by their long legs, some of which are slightly eurved. When working for the egg, what wonder if they continue underground their special craft as ball-making artisans?"

Setting aside the neck of the pear and the jutting tip of the ovoid, details the interpretation of which presents quite other difficulties, there remains the most important mass as regards bulk, the globular mass, a repetition of that which the insect makes outside the burrow; there 
remains the ball with which the Sacred Beetle plays in the sun, sometimes without making any other use of it.

Then what does the globulous form, which presents the most efficacious preventative against desiccation during the heat of summer, do here? Physically, this property of the sphere and of its near neighbour, the ovoid, is undeniable; but these shapes offer only a casual concord with the difficulty overcome. The animal built to roll balls across the fields also fashions balls underground. If the worm be all the better for finding tender foodstuffs under its mandibles to the very end, that is a capital thing for the worm, but it is no reason why we should extol the instinct of the mother.

To complete my conviction, I shall need a portly Dung-beetle who is a total stranger to the pill-making craft in matters of every-day life and who, nevertheless, when the moment of laying is at hand, makes a sudden change in her habits and shapes her harvest into a ball. Is there any such in my neighbourhood? Yes, there is ; and she is one of the handsomest and largest, next to the Sacred Beetle. I speak of the Spanish Copris, who is so rcmarkable for her suddenly sloping corselet and for the extravagant horn surmounting her head.

Thick-set, round, dumpy, slow of gait, the Spanish Copris is certainly not equal to the athletic performances of the Sacred Beetle. The legs, of very middling length and folded under the belly at the least alarm, bear no comparison with the stilts of the pill-rollers. Their stiff and stunted form alone is enough to tell us that the insect would not care to wander about hampered by a rolling ball.

The Copris is, in point of fact, of a sedentary habit. 
Once he has found his provisions, at night or in the evening twilight, he digs a burrow under the heap. It is a rough cave, large enough to hold a big apple. Here is introduced, piecemeal, the matter forming the roof or, at least, lying on the door-sill; here is engulfed, without definite shape, an enormous supply of victuals, bearing eloquent witness to the insect's gluttony. As long as the hoard lasts, the Copris, engrossed in the pleasures of the table, does not return to the surface. The hermitage is not abandoned until the larder is emptied, when the insect recommences its nocturnal searches, finds a new treasure and digs itself a new temporary establishment.

Plying this trade as a setter-in of ordure without preliminary manipulation, the Copris, evidently, is absolutely ignorant, for the time being, of the art of kneading and modelling a globular loaf. Besides, his short, awkward legs seem radically opposed to any such art.

In May, or June at latest, comes laying-time. The insect, itself so ready to fill its belly with the most sordid materials, becomes particular, where the portion of its family is concerned. Like the Sacred Beetle, it now wants the soft produce of the sheep, deposited in a single lump. Even when copious, the cake is buried on the spot in its entirety. Not a trace of it remains outside. Economy demands that it be gathered to the last crumb.

You see: no journey, no carting, no preparations. The cake is carried down to the cellar by armfuls and at the identical spot where it is lying. The insect repeats, with an eye to its grubs, what it did when working for itself. As for the burrow, which is marked by a large mole-hill, it is a roomy cave dug at a depth of some 
twenty centimetres. ${ }^{1}$ I observe a greater width, a greater perfection than in the temporary abodes occupied by the Copris at times of revelry.

But let us leave the insect working in a state of liberty. Tho evidence supplied by chance meetings would be incomplete, fragmentary and disconnected. An examination in the volery is much to be preferred; and the Copris lends himself to this most admirably. Let us first watch the storing.

In the discreet dusk of the twilight, I see him appear on the threshold of his burrow. He has mounted from the depths, he has come to gather his harvest. He has not long to seek : the provisions are there, outside the door, plentifully served and renewed by my care. Timidly, prepared to retreat at the least alarm, he walks up to them with a slow and measured step. The shield cuts and rummages, the fore-legs extract. An armful is separated from the rest, quite a modest armful, crumbling to pieces. The Copris drags it backwards and disappears underground. In less than two minutes, he is back again. Never forgetting his caution, he questions the neighbouring space with the outspread leaflets of his antennæ before crossing the threshold of his dwelling. A distance of two or three inches separates him from the heap. It is a serious matter for him to venture so far. He would have preferred the victuals exactly over his door, forming a roof to the house. This would avoid his having to go out, always a source of anxiety. I have decided otherwise. To facilitate my observations, I have placed the rictuals just on one side. Little by little, the alarmist grows accustomed to the open air and accustomed to my presence, which, for that matter, I

1 About eight inches.-Translator's Note. 
render as discreet as possible. The taking down of the armfuls is repeated indefinitely. They are always shapeless scraps, morsels such as one might pick off with a small pair of pincers.

Having learnt what I want to know about the method of warehousing, I leave the insect to its work, which continues for the best part of the night. On the following days, nothing: the Copris goes out no more. Enough treasure has been amassed in a single night's sitting. Let us wait a while and leave the insect time to stow its harvest as it pleases.

Before the week is out, I dig up the soil of the volery and lay bare the burrow, the victualling of which I have partly followed. As in the fields, it is a spacious hall, with an irregular, surbased ceiling and an almost level floor. In a corner is a round hole, similar to the orifice of the neck of a bottle. This is the business-entrance, opening on a slanting gallery that runs up to the surface. The walls of the house dug in fresh soil are carefully piled up and possess enough power of resistance not to give way under the disturbance produced by my excavations. We can see that, in labouring for the future, the insect has put forth all its talent, all its strength as a digger, to produce lasting work. Whereas the marquee in which we feast is a cavity hurriedly hollowed out, our permanent dwelling is a crypt of larger dimensions and of a much more finished construction.

I suspect that both sexes take part in the master work: at least, I often come upon the couple in the burrows destined for the laying. The roomy and luxurious apartment was no doubt once the wedding-hall; the marriage was consummated under the great vault to the building of which the swain has contributed: a 
gallant way of declaring his ardour. I also suspect the husband of lending a hand to his partner with the harvesting and the storing. From what I have gathered, he too, strong as he is, collects his armfuls and goes down into the crypt. The minute and tricky work goes much faster with two helping. But, once the house is well supplied, he retires discreetly, returns to the surface and goes and settles down elsewhere, leaving the mother to her delicate functions. His part in the family-mansion is ended.

Now what do we find in this mansion, to which we have seen so many tiny loads of provisions lowered? A muddled heap of separate morsels? Not in the least. I always find a single lump, a huge loaf which fills the box, but for a narrow passage all around, just wide enough to leave the mother room to move.

This sumptuous lump, a real Twelfth-Night cake, has no fixed shape. I come across some that are ovoid, suggesting a turkey's egg in form and size; I find some that are a flattened ellipsoid, similar to the common onion; I discover some that are almost round, reminding one of a Dutch cheese; I see some that are circular and slightly raised on the upper surface, like the loaves of the Provençal rustic or, better still, the fougasso à l'i $i u^{1}$ wherewith the Easter festival is celebrated. In every case, the surface is smooth and regularly curved.

There is no mistaking what has happened : the mother has collected and kneaded into one lump the numerous fragments brought down one after the other; out of all those particles she has made a homogeneous piece, by dint of mashing them, amalgamating them, stamping

${ }^{1}$ An egg-shaped cake baked in Provence at Easter.-Translator's Note. 
on them. I repeatedly surprise the baker on the top of the colossal loaf beside which the Sacred Beetle's pill cuts so poor a figure: she goes strolling about on the convex surface, which sometimes measures a decimetre ${ }^{1}$ across; she pats the mass, consolidates it, levels it. I can give but a glance at the curious scene. As soon as she is perceived, the pastry-cook slides down the curved slope and huddles out of sight beneath the pie.

To follow the work further, to study its close detail, we must resort to artifice. The difficulty is almost nil. Either my long practice with the Sacred Bcetle has made me more skilful in methods of research, or else the Copris is less circumspect and endures more readily the annoyance of a long captivity; for I succeed, without the least impediment, in following all the phases of the nestmaking at my heart's ease.

I employ two methods, each fitted to instruct me as to certain particulars. Whenever the voleries supply me with a few large cakes, I move these, with the mother, and place them in my study. The receptacles are of two sorts, according to whether I want light or darkness. For light, I employ glass jars with a diameter more or less the same as that of the burrows, say about a dozen centimetres. 2 At the bottom of each is a thin layer of fresh sand, quite insufficient to allow the Copris to bury herself in it, but convenient, nevertheless, to save the insect from the slippery footing provided by the glass and to give it the illusion of a soil similar to that of which I have deprived it. On this layer the jar receives the mother and her loaf.

I need hardly say that the startled insect would not

13.93 inches.-Translator's Note.

2 Four to five inches,-Translator's Note. 
undertake anything under conditions of light, however softly modulated. It demands complete obscurity, which I produce by means of a cardbrar l box encasing the cylinder. By carefully raising this box a little, I am able, presently, when I feel inclined, to surprise the captive at her work and even to follow her doings for a time. The method, the reader will see, is much simpler than that which I used when I wished to see the Sacred Beetle cngaged in modelling her pear. The easier-going mood of the Copris lends itself to this simplification, which would be none too successful with the other. A dozen of these eclipsed apparatus are thus arranged on the large table in the laboratory. Any one seeing the set would take them for an assortment of groceries in whity-brown paper bags.

For darkness, I use flower-pots filled with fresh, heaped sand. The mother and her cake occupy the lower portion, which is arranged as a nest by means of a cardboard screen forming a ceiling and supporting the sand above. Or else I simply put the mother on the surface of the sand with a supply of provisions. She digs herself a burrow, does her warehousing, makes herself a nest and things happen as usual. In all cases, a sheet of glass used as a lid answers for my prisoners' safety. I rely upon these several dark apparatus to inform me about a delicate point the particulars whereof will be set forth in their proper place.

What do the glass jars covered with an opaque sheath teach us? They teach us much, of a most interesting character, and this to begin with : the big loaf does not owe its curve-which is always regular, notwithstanding its varying form-to any rolling process. The inspection of the natural burrow has already told us that so large 
a mass could not have been rolled into a cavity of which it fills almost the whole space. Besides, the strength of the insect would be unequal to moving so great a load.

Questioned from time to time, the jar repeats the same conclusion for our benefit. I see the mother, hoisted atop the piece, feeling here, feeling there, bestowing little taps, smoothing away the projecting points, perfecting the thing; never do I catch her looking as though she wanted to turn the block. It is as clear as daylight: rolling has nothing whatever to do with the matter.

The dough-maker's assiduity, her patient cares make me suspect a delay in the manufacture whereof I was far from dreaming. Why so many after-touches to the block, why so long a wait before employing it ? A week and more passes, in fact, before the insect, ever pressing and polishing, decides to use its hoard.

The baker, when he has kneaded his dough to the desired extent, collects it into a single heap in a corner of the kneading-trough. The heat of the panary fermentation smoulders better in the heart of the voluminous mass. The Copris knows this secret of the bakehouse. She collects the sum total of her harvests into a single lump; she carefully kncads the whole into a provisional loaf which she gives time to improve by means of an inner labour that makes the paste more palatable and gives it a degree of consistency favourable to subsequent manipulations. As long as the chemical work remains unfinished, both the journeyman-baker and the Copris wait. To the insect this means a long spell, a week at least.

It is done. The baker's man divides his lump into smaller lumps, each of which will become a loaf. The 
Copris acts likewise. By means of a circular gash made with the cleaver of the shield and the saw of the fore-legs, she separates from the main body a section of the prescribed size. For this stroke of the trencher, no hesitation is needed, no after-touches that add or subtract. Off-hand and with a plain, decisive cut, a lump is obtained of the requisite bulk.

It now becomes a question of shaping it. Clasping it as best it can in its short arms, so incompatible, one would think, with work of this kind, the insect rounds

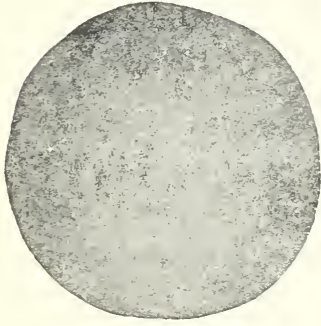

Fig. 5.-The Copris's pill : first state. the section by the one and only means of pressure. It gravely moves about the hitherto shapeless ball, climbs up, climbs down; it turns to left and right, above and below; methodically, it presses a little more here, a little less there; it improves by new touches, with unchanging patience; and, in twentyfour hours' time, the angular piece has become a perfect sphere, the size of a plum. In a corner of her crammed studio, the podgy artist, with hardly room to move, has finished her work without once shaking it on its base; by dint of time and patience, she has obtained the geometrical globe which her clumsy tools and her confined space seemed bound to refuse her.

The insect continues for a long time yet to improve and lovingly to polish its sphere, gently passing its foot to and fro until the least protuberance has disappeared. Its finikin after-touches look as though they would never 


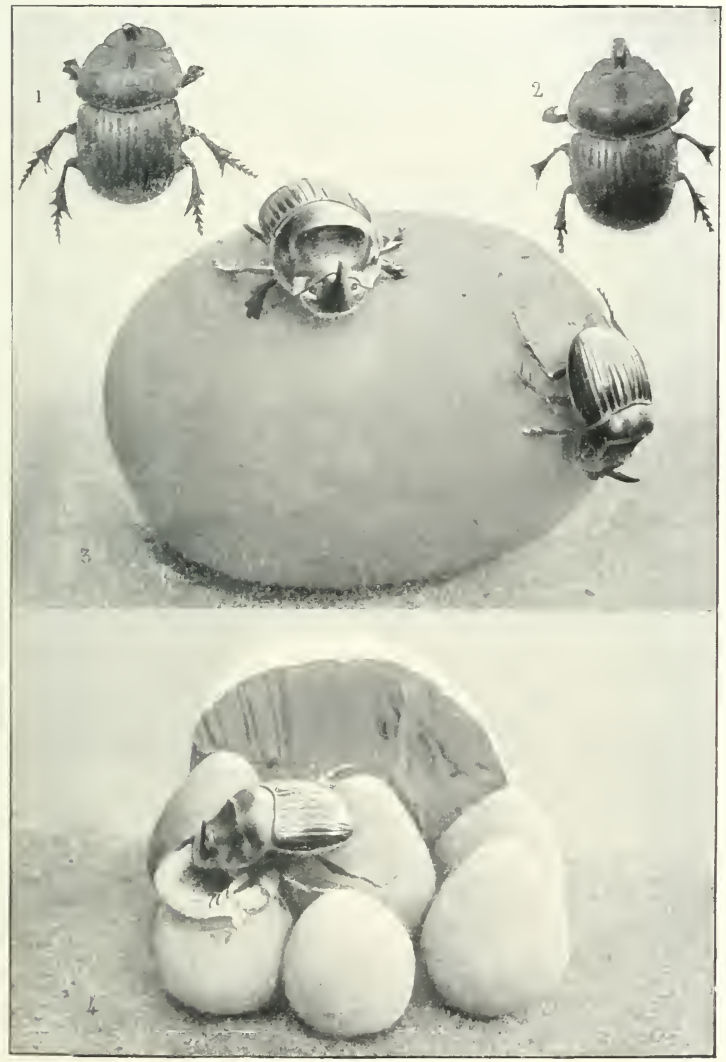

1 and 2. The Spanish Copris, male and female.

3. The pair jointy kneading the big loaf, which, divided into egorshaped pills, will furnish provisions for etch grub of the browd.

4. The mother alone in hex burrow: five pills are already finished; a sixth is in process of construction. 

be done. Towards the end of the second day, however, the globe is pronounced right and proper. The mother climbs to the dome of her edifice and there, still by simple pressure, hollows out a shallow crater. In this basin the egg is laid.

Then, with extreme caution, with a delicacy that is most surprising in such rough tools, the lips of the crater are brought together so as to form a vaulted roof over the egg. The mother slowly turns, rakes a little, draws

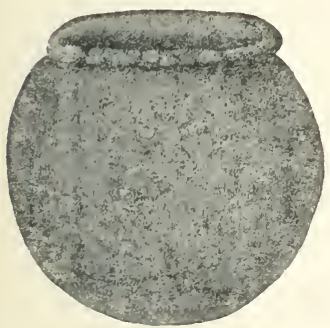

Fig. 6.-The Spanish Copris's pill dug out cupwise to receive the egg.

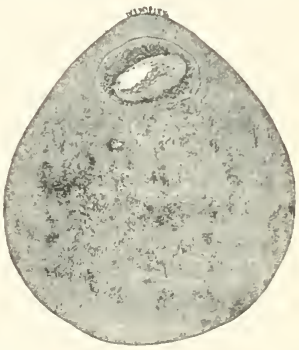

Fig. 7.-The Sylanish Copris's pill : section showing the hatching-chamber and the egg.

the material upwards and finishes the closing. This is the most ticklish work of all. A careless pressure, a miscalculated thrust might easily jeopardize the life of the germ under its slender ceiling.

From time to time, the work of closing is suspended. The mother, motionless, with lowered forehead, seems to auscultate the underlying cavity, to listen to what is happening within. All's well, it seems; and the patient labour is resumed : a fine scraping of the sides towards 


\section{THE LIFE AND LOVE OF THE INSECT}

the summit, which tapers a little and lengthens out. In this way, an ovoid with the small end uppermost replaces the original sphere. Under the more or less projecting nipple is the hatching-chamber, with the egg. Twentyfour hours more are spent in this minute work. Total: four times round the clock and sometimes longer to construct the sphere, hollow it out basinwise, lay the egg and shut it in by transforming the sphere into an ovoid.

The insect goes back to the cut loaf and helps itself to a second slice, which, by the same manipulations as before, becomes an ovoid sheltering an egg. The surplus suffices for a third ovoid, pretty often even for a fourth. I have never seen this number exceeded when the mother had at her disposal only the materials which she had heaped up in the burrow.

The laying is over. Here is the mother in her retreat, which is almost filled by the three or four cradles standing one against the other, with their poles jutting upwards. What will she do now? Go away, no doubt, to recruit her strength a little out of doors, after a prolonged fast. $\mathrm{He}$ who thinks this is mistaken. She remains. And yet she has eaten nothing since she came underground, taking good care not to touch the loaf, which, divided into equal portions, will be the food of the family. The Copris is touchingly scrupulous in the matter of the inheritance: she is a devoted mother, who braves hunger lest her offspring should starve.

She braves it for a second reason: to mount guard around the cradles. From the end of June onwards, the burrows are hard to find, because the mole-hills disappear through the action of some storm, or the wind, or the feet of the passers-by. The few which I succeed in cliscovering always contain the mother dozing beside a 
group of pills, in each of which a grub, now nearing its complete development, feasts on the fat of the land.

My dark apparatus, flower-pots filled with fresh sand, confirm what the fields have taught me. Buried with provisions in the first fortnight in May, the mothers do not reappear on the surface, under the glass lid. They keep hidden in the burrow after laying their eggs; they spend the sultry dog-days with their ovoids, watching them, no doubt, as the glass jars, rid of subterranean mysteries, tell us.

They come up again at the time of the first autumnal rains, in September. But by then the new generation has attained its perfect form. The mother, therefore, enjoys underground that rare privilege for the insect, the delight of knowing her family; she hears her sons scratching at the shell to obtain their liberty; she is present at the bursting of the casket which she has fashioned so conscientiously; maybe she helps the exhausted weaklings, if the ground have not been cool enough to soften their cells. Mother and progeny leave the subsoil together and arrive together at the autumn banquets, when the sun is mild and the ovine manna plentiful along the paths. 



\section{THE ONTHOPHAGI}





\section{CHAPTER VI}

\section{THE ONTHOPHAGI}

After the notabilities of the Dung-beetle tribe, there remain, in the very limited radius of my research, the small fry of the Onthophagi, of whom I could gather a dozen different species around my house. What will these little ones teach us?

Even more zealous than their larger comrades, they are the first to hasten to the exploiting of the heap left by the passing mule. They come up in crowds and stay long, working under the spread table that gives them shade and coolness. Turn over the heap with your foot. You will be surprised at the swarming population whose presence no outward sign betrayed. The largest are searce the size of a pea, but many are much smaller still, are dwarfs, no less busy than the others, no less eager to crumble the filth whose prompt disappearanee the public health demands.

In works of major interest, there is none like the humble, with their concerted weakness, for realizing immense strength. Swollen by numbers, the next to nothing becomes an enormous total.

Hurrying in detachments at the first news of the event, assisted moreover in their wholesome task by their partners, the Aphodians, who are as weak as they, the tiny Onthophagi soon clear the ground of its dirt. Not that 
their appetite is equal to the consumption of such plentiful provisions. What food do those pigmies need? An atom. But that atom, selected from among the exudations, must be hunted amid the fragments of the masticated fodder. Hence, an endless division and subdivision of the lump, reducing it to crumbs which the sun sterilizes and the wind dispels. As soon as the work is doneand very well done-the troop of scavengers goes in search of another refuse-yard. Outside the period of intense cold, which puts a stop to all activity, they know no dead season.

And do not run away with the idea that this filthy task entails an inelegant shape and a ragged dress. The insect knows none of our squalor. In its world, a navvy dons a sumptuous jerkin; an undertaker decks himself in a triple saffron sash; a wood-cutter works in a velvet coat. In like manner, the Onthophagus has his own luxury. True, the costume is always severe : brown and black are the predominant colours, now dull, now polished as ebony ; but, on this background, what details of sober and graceful ornament! The graver's work completes the beauty of the dress. Tiny chasings in parallel grooves, gnarly beads, dainty rows of knobs, seed-plots of pearly papillæ are distributed in profusion among nearly all of them. Yes, the little Onthophagi, with their stunted bodies and their nimble activity, are really pretty to look at.

And then how original are their frontal decorations! These peace-lovers delight in the panoply of war, as though they, the inoffensive ones, thirsted for battle. Many of them crown their heads with threatening horns. Let us mention that horned one whose story will occupy us more particularly. I mean Onthophagus 


\section{PLATE V}
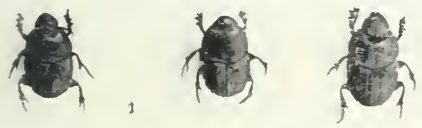

2
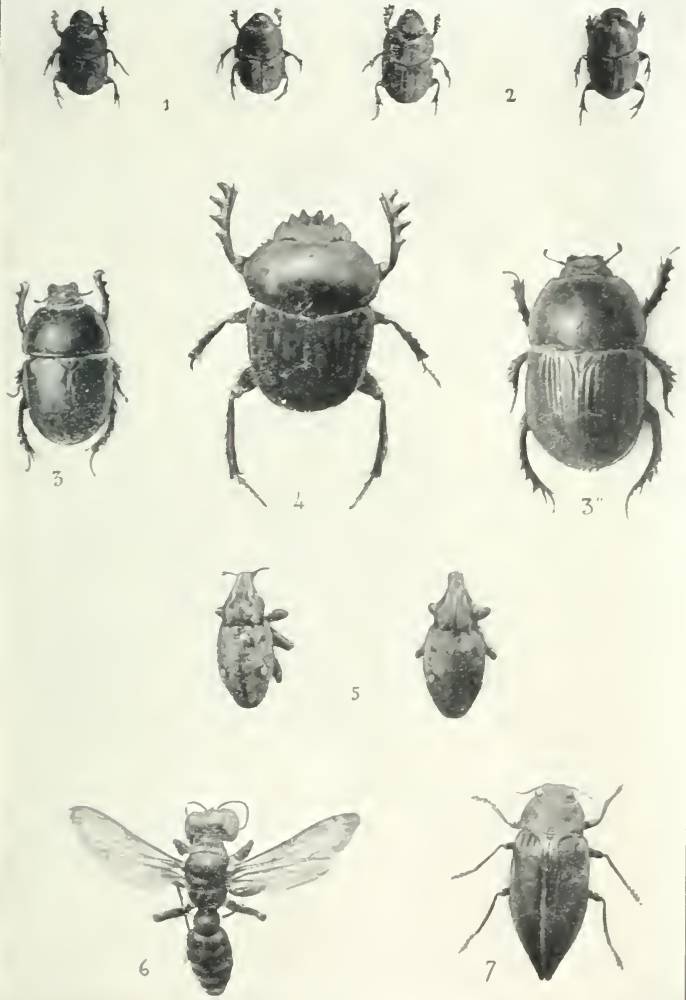

1. Onthoplatus Turnes.

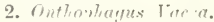

3. The stercoraceons Geotrune.

4. The Wile-neckels siritb.

5. Cleonus Gpthalmirus. 6. remris Tuber ulatu. 7. Liuprestis Liea. 

Taurus, clad in raven black. He wears a pair of long horns, gracefully curved and branching to either side. No pedigree bull, in the Swiss meadows, can match them for curve or elegance.

The Onthophagus is a very indifferent artist: his nest is a rudimentary piece of work, hardly fit to be acknowledged. I obtain it in profusion from the six species which I have brought up in my jars and flower-pots. Onthophagus Taurus alone provides me with nearly a hundred; and I find no two precisely alike, as pices should be that come from the same mould and the same laboratory.

To this lack of exact similarity, we must add inaccuracy of shape, now more, now less accentuated. It is easy, however, to recognize among the bulk the prototype from which the clumsy nest-builder works. It is a sack shaped like a thimble and standing erect, with the spherical thimble-end at the bottom and the circular opening at the top.

Sometimes, tho insect establishes itself in the central region of my apparatus, in the heart of the earthy mass ; then, the resistance being the same in every direction, the sack-like shape is pretty accurate. But, generally, the Onthophagus prefers a solid basis to a dusty support and builds against the walls of the jar, especially against the bottom wall. When the support is vertical, the sack is a short cylinder divided lengthwise, with a smooth, flat surface against the glass and a rugged convexity every elsewhere. If the support be horizontal, as is most frequently the case, the cabin is a sort of undefined oval pastille, flat at the bottom, bulging and vaulted at the top. To the general inaccuracy of these contorted shapes, ruled by no very definite pattern, we must add the coarseness of the surfaces, all of which, with the 
exception of the parts touching the glass, are covered with a crust of sand.

The manner of procedure explains this uncouth exterior. As laying-time draws nigh, the Onthophagus bores a cylindrical pit and descends underground to a middling depth. Here, working with the shield, the chine and the fore-legs, which are toothed like a rake, he forces back and heaps around him the materials which he has moved, so as to obtain as best he may a nest of suitable size.

The next thing is to cement the crumbling walls of the cavity. The insect climbs back to the surface by way of its pit; it gathers on its threshold an armful of mortar taken from the cake whereunder it has elected to set up house ; it goes down again with its burden, which it spreads and presses upon the sandy wall. Thus it produces a concrete casing, the flint of which is supplied by the wall itself and the cement by the produce of the sheep. After a few trips and repeated strokes of the trowel, the pit is plastered on every side; the walls, encrusted with grains of sand, are no longer liable to give way.

The cabin is ready : it now wants only a tenant and stores. First, a large free space is contrived at the bottom : the hatching-chamber, on whose inner wall the egg is laid. Next comes the gathering of the provisions intended for the worm, a gathering made with nice precautions. Lately, when building, the insect worked upon the outside of the doughy mass and took no notice of the earthy blemishes. Now, it penetrates to the very centre of the lump, through a gallery that looks as though it were contrived with a punch. When trying a cheese, the buyer employs a hollow cylindrical taster, which he 
drives well in and pulls out with a sample taken from the middle of the cheese. The Onthophagus, when collecting for her grub, goes to work as though equipped with one of these tasters. She bores an exactly round hole into the piece which she is exploiting; she goes straight to the middle, where the material, not being exposed to the contact of the air, has kept more savoury and pliable. Here and here alone are gathered the armfuls which, gradually stowed away, kneaded and heaped up to the requisite extent, fill the sack to the top. Finally, a plug of the same mortar, the sides of which are made partly of sand and partly of stercoral cement, roughly closes the cell, in such a way that an outward inspection does not allow one to distinguish front from back.

To judge the work and its merit, we must open it. A large empty space, oval in shape, occupies the rear end. This is the birth-chamber, huge in dimensions compared with its content, the egg fixed on the wall, sometimes at the bottom of the cell and sometimes on the side. The egg is a tiny white cylinder, rounded at either end and measuring a millimetre ${ }^{1}$ in length immediately after it is laid. With no other support than the spot on which the oviduct has planted it, it stands on its hind-end and projects into space.

A more or less enquiring glance is quite surprised to find so small a germ contained in so large a box. What does that tiny egg want with all that space? When carefully examined within, the walls of the chamber prompt another question. They are coated with a fine greenish pap, semi-fluid and shiny, the appearance of which does not agree with the outward or inward aspect of the lump from which the insect has extracted its

1 .039 inch.-Translator's Note. 
materials. A similar lime-wash is observed in the nest which the Sacred Beetle, the Copris, the Sisyphus, the Geotrupe and other makers of stereoraceous preserves contrive in the very heart of the provisions, to receive the egg ; but nowhere have I seen it so plentiful, in proportion, as in the hatehing-chamber of the Onthophagus. Long puzzled by this brothy wash, of which the Saered Beetle provided me with the first instance, I began by taking the thing for a layer of moisture oozing from the bulk of the vietuals and eolleeting on the surface of the enclosure without other effort than eapillary aetion. That was the interpretation which I accepted originally.

I was wrong. The truth is worthy of attention in a very different way. To-day, better-informed by the Onthophagus, I know that this lime-wash itself, this semi-fluid eream, is the produet of maternal foresight.

What, then, is this lime-wash found in every eell? The answer is compulsory : it is a produee of the mother, a special gruel, a milk-food elaborated for the benefit of the new-born grub.

The young Pigeon puts his beak into that of his parents, who, with convulsive efforts, force down his gullet first a easeous mash seereted in the crop and next a broth of grains softened by being partially digested. He is fed upon disgorged foods, which are helpful to the weaknesses of an inexperieneed stomach. The grub of the Onthophagus is brought up in mueh the same way, at the start. To assist its first attempts at swallowing, the mother prepares for it, in her erop, a light and strengthening eream.

To pass the dainty from mouth to mouth is, in her case, impossible : the eonstruetion of other cells keeps her busy elsewhere. Moreover-and this is a more serious detail-the laying takes place egg by egg, at very long 
intervals, and the hatching is pretty slow: time would fail, had the family to be brought up in the manner of the Pigeons. Another method is perforce needed. The childish pap is disgorged all over the walls of the cabin in such a way that the nursling finds itself surrounded by an abundance of bread-and-jam, in which the bread, the food of the sturdy age, is represented by the uncooked material, as supplied by the sheep, whereas the jam, the mess of the puny age, is represented by the same material daintily prepared beforehand in the mother's stomach. We shall see the babe presently lick first the jam, all around it, and then stoutly attack the bread. A child among ourselves would behave no otherwise.

I should have liked to catch the mother in the act of disgorging and spreading her broth. I was not able to succeed. Things happen in a narrow retreat, which the eye cannot enter when the pastry-cook is busy ; and also her fluster at being exhibited in broad daylight at once stops the work.

If direct observation be lacking, at least the appearance of the material speaks very clearly and tells us that the Onthophagus, here rivalling the Pigeon, but with a different method, disgorges the first mouthfuls for her sons. And the same may be said of the other Dungbeetles skilled in the art of building a hatching-chamber in the centre of the provisions.

No elsewhere, in the insect order, except among the Apidx, who prepare disgorged food in the shape of honey, is this affection present. The Dung-workers edify us with their morals. Several of them practise association in couples and found a household; several anticipate the suckling, the supreme expression of maternal solicitude, by turning their crop into a nipple. Life has its freaks. 
It scttles amid ordure the creatures most highly-endowed with family qualities. True, from there it mounts, with a sudden flight, to the sublimities of the bird.

The little worm is hatched in about a week : a strange and paradoxical being. On its back, it has an enormous sugar-loaf hump, the weight of which drags it over and capsizes it each time it tries to stand on its legs and walk. At every moment, it staggers and falls under the burden of the hunch.

Unable to keep its hump upright, the grub of the Onthophagus lies down on its side and licks the cream of its cell all around it. There is eream everywhere, on the ceiling, on the walls, on the floor. As soon as one spot is thoroughly bared, the consumer moves on a little with the help of its well-shaped legs; it capsizes again and starts licking again. The room is large and plentifully supplied; and the jam-diet lasts some time.

The fat babies of the Geotrupe, the Copris and the Sacred Beetle finish at one brief sitting the dainty wherewith their cabined lodge is hung, a dainty scantily served and just sufficient to stimulate the appetite and prepare the stomach for a coarser fare; but the Onthophagus grub, that lean pigmy, has enough to last it for a week and more. The spacious natal chamber, which is out of all proportion with the size of the nursling, has permitted this wastefulness.

At last, the real loaf is attacked. In about a month, everything is consumed, except the wall of the sack. And now the splendid part played by the hump stands revealed. Glass tubes, prepared in view of events, allow me to follow the more and more plump and hunch-backed grub at work. I see it withdraw to one end of the cell, which has become a crumbling ruin. Here it builds a 
casket in which the transformation will take place. Its materials are the digestive residuum, converted into mortar and heaped up in the hump. The stercoral architect is about to construct a masterpiece of elegance out of its own ordure, held in reserve in that receptacle.

I follow its movements under the magnifying-glass. It buckles itself, closes the circuit of the digestive apparatus, brings the two poles into contact and, with the end of its mandibles, seizes a pellet of dung ejaculated at that moment. This pellet, moulded and measured to perfection, is very neatly gathered. A slight bend of the nock sets the rubble-stone in place. Others follow, laid one above the other in minutely regular courses. Giving a tap here and there with its feelers, the grub makes sure of the stability of the parts, their accurate binding, their orderly arrangement. It turns round in the centre of the work as the edifice rises, even as a mason does when building a tower.

Sometimes, the laid stone becomes loose, because the cement has given way. The worm takes it up again with its mandibles, but, before replacing it, coats it with an adhesive moisture. It holds it to its anus, whence trickles, on the moment, almost imperceptibly, a gummy consolidating extract. The hump supplies the materials ; the intestines give, if necessary, the connecting glue.

In this way, a nice house is produced, ovoid in shape, polished as stucco within and adorned on the outside with slightly projecting scales, similar to those on a cedarcone. Each of these scales is one of the rubble-stones out of the hump. The casket is not large : a cherry-stone would about represent its dimensions; but it is so accurate, so prettily fashioned that it will bear comparison with the finest products of entomological industry. 


\section{CHAPTER VII}

\section{A BARREN PROMISE}

Is the nymph of Onthophagus Taurus there rises, on the front edge of the corselet, a single horn, as strong as the two others and shaped like a cylinder ending in a conical knob. It points forward and is fixed in the middle of the frontal crescent, projecting a little beyond it. The arrangement is gloriously original. The carvers of hieroglyphics would have beheld in it the crescent of Isis wherein dips the edge of the world.

Other singularities complete the curious nymph. To right and left, the stomach is armed, on either side, with four little horns resembling crystal spikes. Total, eleven pieces on the harness: two on the forehead; one on the thorax ; eight on the abdomen. The beast of yore delighted in queer horns: certain reptiles of the geological period stuck a pointed spur on their upper eyelids. The Onthophagus, more daring, sports eight on the sides of his belly, in addition to the spear which he plants upon his back. The frontal horns may be excused: they are pretty generally worn; but what does he propose to do with the others? Nothing. They are passing fancies, jewels of early youth; the adult insect will not retain the least trace of them.

The nymph matures. The appendages of the forehead, at first quite crystalline, now show, transparently, a streak 
of reddish brown, curved arc-wise. These are real horns taking shape, consistency and colour. The appendage of the corselet and those of the belly, on the other hand, preserve their glassy appearance. They are barren sacks, void of any self-developing germ. The organism produced them in an impetuous moment; now, scornful, or perhaps powerless, it allows the work to wither and become useless.

When the nymph sheds its covering and the fine tunic of the adult form is torn, these strange horns crumble into shreds, which fall away with the rest of the cast clothing. In the hope of finding at least a trace of the vanished things, the lens in vain explores the bases but lately occupied. There is nothing appreciable left : smoothness takes the place of protuberance; nullity succeeds to reality. Of the accessory panoply that promised so much, absolutely naught remains: ererything has disappeared, evaporated, so to speak.

Onthophagus Taurus is not the only one endowed with those fleeting appendages, which vanish wholly when the nymph sheds its clothes. The other members of tho tribe possess similar horny manifestations on their bellies and corselets. These all disappear entirely in the perfect insect.

A simple setting forth of the facts does not suffice us : we should like to guess at the motive of this corniculate display. Is it a vague memory of the customs of olden time, when life spent its excess of young sap upon quaint creations, banished to-day from our better-balanced world? Is the Onthophagus the dwarfed representative of an old race of horned animals now extinct? Does it give us a faint image of the past?

The surmise rests upon no valid foundation. The 
Dung-beetle is recent in the general chronolngy of created beings; he ranks among the last-comers. With him there is no means of going back to the mists of the past, so favourable to the invention of imaginary precursors. The geological layers and even the lacustrian layers, rich in Diptera and Weevils, have so far furnished not the slightest relic of the Dung-workers. This being so, it is wiser not to refer to distant horned ancestors as accounting for their degenerate descendant, the Onthophagus.

Since the past explains nothing, let us turn to the future. If the thoracic horn be not a reminiscence, it may be a promise. It represents a timid attempt, which the ages will harden into a permanent weapon. It lets us assist at the slow and gradual evolution of a new organ; it shows us life working on a portion of the adult's corselet, which does not yet exist, but which is to exist some day. We take the genesis of the species in the act ; the present teaches us how the future is prepared.

And what does the insect that has conceived the ambition of later planting a spear upon its chine propose to make of its projected work? At least as an adjunct of masculine finery, the thing is in fashion among various foreign Scarabs that feed themselves and their grubs on vegetable matters in a state of decomposition. These giants among the wing-cased tribe delight in associating their placid corpulence with halberds terrible to gaze upon.

Look at this one-Dynastes Hercules his name-an inmate of the rotten tree-stumps under the torrid WestIndian skies. The peaceable colossus well deserves his name: he measures three inches long. Of what service can the threatening rapier of the corselet and the toothed lifting-jack of the forehead be to him, unless it 
be to make him look grand in the presence of his female, herself deprived of these extravagances? Perhaps also they are of use to him in certain works, even as the trident helps Minotaurus in crumbling the pellets and carting the rubbish. Implements of which we do not know the use always strike us as singular. Having never associated with the West-Indian Hercules, I must content myself with suspicions touehing the purpose of his fearsome equipment.

Well, one of the subjects in my voleries would achieve a similar savage finery if he persisted in his attempts. I speak of Onthophagus Vacca. His nymph has on its forehead a thick horn, one only, bent backward; on its corselet it possesses a like horn, jutting forward. The two, approaching their tips, look like a sort of pincers. What does the insect lack in order to aequire, on a smaller seale, the eccentric ornament of the West-Indian Scarab ? It laeks perseveranee. It matures the appendage of the forehead and allows that of the corselet to perish atrophied. It succeeds no better than Onthophagus Taurus in its attempt to grow a pointed stake upon its chine ; it loses a glorious opportunity of making itself fine for the wedding and terrible in battle.

The others are no more suceessful. I bring up six different speeies. All, in the chrysalis state, possess the thoracic horn and the eight-pointed ventral eoronet; not one benefits by these advantages, which disappear altogether when the adult splits its case. My near neighbourhood numbers a dozen species of Onthophagi; the world contains some hundreds. All, natives and foreigners, have the same general strueture; all most probably possess the dorsal appendage at an early age; and none of them, in spite of the variety of the climate, torrid in 
one place, moderate in another, has succeeded in hardening it into a permanent horn.

Could the future not complete a work the design of which is so very clearly traced? We ask ourselves this the more readily inasmuch as every appearance encourages the question. Examine under the magnifyingglass the frontal horns of Onthophagus Taurus in the pupa state; then consider as carefully the spear upon the corselet. At first, there is no difference between them, except the general configuration. In both cases, we find the same glassy aspect, the same sheath swollen with a crystalline moisture, the same incipient organ plainly marked. A leg in formation is not more clearly declared than the horn on the corselet or those on the forehead.

Can time be lacking for the thoracic growth to organize itself into a stiff and lasting appendage? The evolution of the nymph is swift ; the insect is perfect in a few weeks. Could it not be that, though this brief space suffice to promote the maturity of the horns on the forehead, the thoracic horn requires a longer time to ripen? Let us prolong the nymphal period artificially and give the germ time to develop itself. It scems to me that a decrease of temperature, moderated and maintained for some weeks, for months if necessary, should be capable of bringing about this result, by delaying the progress of the evolution. Then, with a gentle slowness, favourable to delicate formations, the promised organ will crystallize, so to speak, and become the spear heralded by appearances.

The experiment attracted me. I was unable to undertake it for lack of the means whereby to produce a cold, eren and lasting temperature. What should I hare obtained if my penury had not made me abandon the 
enterprise? A retarding of the progress of the metamorphosis, but nothing more, apparently. The horn on the corselet would have persisted in its sterility and, sooner or later, would have disappeared.

I have reasons for my conviction. The abode of the Onthophagus while engaged on his metamorphosis is not deep down; variations of temperature are easily felt. On the other hand, the seasons are capricious, especially the spring. Under the skies of Provence, the months of May and June, if the mistral lend a hand, have periods when the thermometer drops in such a way as to suggest a return of winter.

To these vicissitudes let us add the influence of a more northerly climate. The Onthophagi occupy a wide zone of latitude. Those of the north, less favoured by the sun than those of the south, can, if changing circumstances assist at the time of the transformation, undergo long weeks of a decreased temperature which spins out the work of evolution and ought therefore to permit the thoracic armour, at long intervals and casually, to consolidate into a horn. Here and there, then, the conditions of a moderate, or even cold temperature, at the time of the nymphosis, are realized without the aid of my artifices.

Well, what becomes of this surplus time placed at the service of the organic labour? Does the promised horn ripen? Not a bit of it: it withers just as it does under the stimulus of a hot sun. The records of entomology have never spoken of an Onthophagus carrying a horn upon his corselet. No one would even have suspected the possibility of such an armour, if I had not rumoured the strange appearance of the nymph. The influence of climate, therefore, goes for nothing here. 
Pushed further still, the question becomes more complicated. The horny appendages of the Onthophagus, of the Copris, of Minotaurus and of so many others are the male's prerogative; the female is without them or wears them only on a reduced and very modest scale. We must look upon these corniculate products as personal ornaments much rather than as implements of labour. The male makes himself fine for the pairing; but, with the exception of Minotaurus, who pins down the dry pellet that needs erushing and holds it in position with his trident, I know none that uses his armour as a tool. Horns and prongs on the forehead, crests and crescents on the corselet are jewels of masculine vanity and nothing more. The other sex requires no such baits to attract suitors : its femininity is enough; and finery is neglected.

Now here is something to give us food for thought. The nymph of the Onthophagus of the female sex, a nymph with an unarmed forehead, carries on its thorax a vitreous horn as long, as rich in promise as that of the other sex. If this latter excrescence be an incompletelyrealized incipient ornament, then the former would be so too, in which case the two sexes, both anxious for self-embellishmerit, would work with equal zeal to grow a horn upon their thorax. We should be witnessing the genesis of a species that would not be really an Onthophagus, but a derivative of the group; we should be beholding the commencement of singularities banished hitherto from among the Dung-beetles, none of whom, of either sex, has thought of planting a spear upon his chine. Stranger still: the female, always the more humbly attired throughout the entomological order, would be vying with the male in her propensity for eccentric adornment. An ambition of this sort leaves me incredulous. 
We must therefore believe that, if the possibilities of the future should ever produce a Dung-beetle carrying a horn upon his corselet, this upsetter of present customs will not be the Onthophagus succeeding in maturing the thoracic appendage of the nymph, but rather an insect resulting from a new model. The creative power throws aside the old moulds and replaces them by others, fashioned with fresh care, after plans of an inexhaustible variety. Its laboratory is not a peddling rag-fair, where the living assume the cast clothes of the dead : it is a medallist's studio, where each effigy receives the stamp of a special die. Its treasure-house of forms, of unbounded wealth, excludes any niggardly patching of the old to make the new. It breaks up every mould once used ; it does away with it, without resorting to shabby after-touches.

Then what is the meaning of those horny preparations, which are always blighted before they come to aught? Without feeling greatly abashed by my ignorance, I confess that I am absolutely unable to say. In the absence of an appearance of learning, my answer has at least one merit, that of perfect sincerity. 

A DUNG-BEE'TLE OF 'THE PAMT'AS 



\section{CHAPTER VIII}

\section{A DUNG-BEETLE OF THE PAMPAS}

To travel over the world, by land and sea, from pole to pole; to cross-question life, under every clime, in the infinite variety of its manifestations : that surely would be glorious luck for him that has eyes to see with; and it formed the radiant dream of my young years, at the time when Robinson Crusoe was my delight. These rosy illusions, rich in voyages, were soon succeeded by dull, stay-at-home reality. The jungles of India, the virgin forests of Brazil, the towering crests of the Andes, beloved by the condor, were reduced, as a field for exploration, to a patch of pebble-stones enclosed within four walls.

Heaven forfend that I should complain! The gathering of ideas does not necessarily imply distant expeditions. Jean-Jacques Rousseau herborized with the bunch of chickweed whereon he fed his canary ; Bernardin de SaintPierre discovered a world on a strawberry-plant that grew by accident in a corner of his window; Xavier de Maistre, using an arm-chair by way of post-chaise, made one of the most famous of journeys around his room. ${ }^{1}$

This manner of seeing country is within my means, always excepting the post-chaise, which is too difficult to drive through the brambles. I go the circuit of my

1 Voyage autour de ma chambre (1795).-Translator's Note. 


\section{THE LIFE AND LOVE OF THE INSECT}

enclosure over and over again, a hundred times, by short stages; I stop here and I stop there; patiently, I put questions; and, at long intervals, I receive some scrap of a reply.

The smallest insect village has become familiar to me : I know each fruit-branch where the Praying Mantis perches; each bush where the pale Italian Cricket strums amid the calmness of the summer rights; each wad-clad blade of grass scraped by the Anthidium, that maker of cotton bags; each cluster of lilac worked by the Megachile, the leaf-cutter.

If cruising among the nooks and corners of the garden do not suffice, a longer voyage shows ample profit. I double the cape of the neighbouring hedges and, at a few hundred yards, enter into relations with the Sacred Beetle, the Capricorn, the Geotrupe, the Copris, the Dectus, the Cricket, the Green Grasshopper, in short, with a host of tribes the unfolding of whose story would exhaust a human life. Certainly, I have plenty, I have too much to do with my near neighbours, without going and wandering in distant regions.

And then, besides, roaming the world, scattering one's attention over a host of subjects, is not observing. The travelling entomologist can stick numerous species, the joy of the collector and the nomenclator, into his boxes; but to gather circumstantial documents is a very different matter. A Wandering Jew of science, he has no time to stop. Where a prolonged stay would be necessary to study this or that fact, he is hurried by the next stage. We must not expect the impossible of him in these conditions. Let him pin his specimens to cork tablets, let him steep them in tafia jars and leave to the sedentary the patient observations that require time. 
This explains the extreme penury of history outside the dry descriptions of the nomenclator. Overwhelming us with its numbers, the exotic insect nearly always preserves the secret of its manners. Nevertheless, it were well to compare what happens under our eyes with that which happens elsewhere; it were excellent to see how, in the same corporation of workers, the fundamental instinct varies with climatic conditions.

Then my travelling regrets return, vainer to-day than ever, unless one could find a seat on the carpet of which we read in the Arabian Nights, the famous carpet whercon one had but to sit to be carried whithersoever he pleased. O marvellous conveyance, far prefcrable to Xavier de Maistre's post-chaise! If only I could find a little corner on it, with a return-ticket !

I do find it. I owe this unexpected good fortune to a Christian Brother, to Brother Judulian, of the Lasalle College at Buenos Ayres. His modesty would be offended by the praises which his debtor owes him. Let us simply say that, acting on my instructions, his eyes take the place of mine. He seeks, finds, observes, sends me his notes and his discoverics. I observe, seek and find with him, by correspondence.

It is done : thanks to this first-rate collaborator, I have my seat on the magic carpet. Behold me in the pampas of the Argentine Republic, eager to draw a parallel between the industry of the Dung-beetles of Sérignan ${ }^{1}$ and that of their rivals in the western hemisphere.

A glorious beginning! An accidental find procures me, to start with, Phanæus Milo, a magnificent insect, blue-black all over. The corselet of the male juts forward, over the head, in a short, broad, flattened

${ }^{1}$ Sérignan, in Provence, is the author's birth-place.-Translator's Note. 


\section{THE LIFE AND LOVE OF THE INSECT}

horn, ending in a trident. The female replaces this ornament with simple folds. Both carry, in front of their shield, two spikes which form a trusty diggingimplement and also a scalpel for dissecting. The insect's squat, sturdy, four-cornered build resembles that of Onitis Olivieri, one of the rarities of the neighbourhood of Montpellier.

If similarity of shape implied parity of work, we ought unhesitatingly to attribute to Phanæus Milo short, thick puddings like those made by Olivier's Onitis. Alas, structure is a bad guide where the instinct is concerned! The square-chined, short-legged Dung-worker excels in

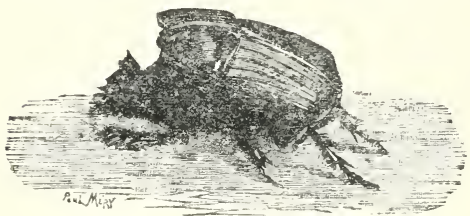

Fig. 8.-Phanzus Milo. the art of manufacturing gourds. The Sacred Beetle himself supplies none that are more perfect nor, above all, more capacious. The thick-set insect astonishes me with the elegance of its work, which is irreproachable in its geometry: the neck is less slender, but nevertheless combines grace with strength. The model seems derived from some Indian calabash, the more so as the neck opens wide and the belly is engraved with an elegant guilloche, produced by the insect's tarsi. One seems to see a pitcher protected by a wicker-work covering. The whole is able to attain and even exceed the size of a hen's egg.

It is a very curious piece of work and of a rare perfection, especially when we consider the artist's clumsy and massive build. Once again, the tool does not make the 
workman, among Dung-beetles any more than among ourselves. To guide the modeller there is something better than a set of tools : there is what I would call the bump, the genius of the animal.

Phanæus Milo laughs at difficulties. He does more: he laughs at our classifications. The word Dung-beetle implies a lover of dung. He sets no value on it, either for his own use or for that of his offspring. What he wants is the sanies of corpses. $\mathrm{He}$ is to be found under the carcasses of birds, dogs or eats, in the company of the undertakers-in-ordinary. The gourd of which I give a drawing overleaf was lying in the earth under the remains of an owl.

Let him who will explain this conjunction of the appetites of the Necrophore with the talents of the Scarab. As for me, baffled by tastes which no one would suspect from the mere appearance of the insect, I give it up.

I know in my neighbourhood one Dung-beetle and one alone who also works among the remains of dead bodies. This is Onthophagus Ovatus (Lin.), a constant frequenter of dead moles and rabbits. But the dwarf undertaker does not on that account scorn stercoraceous fare: he feasts upon it like the other Onthophagi. Perhaps there is a two-fold diet here : the bun for the adult; the highlyspiced, far-gone meat for the grub.

Similar facts are encountered elsewhere with different tastes. The predatory Hymenopteron takes her fill of honey drawn from the nectaries of the flowers, but feeds her little ones on game. Game first, then sugar, for the same stomach. How that digestive pouch must change on the road! And yet no more than our own, which scorns in later life that which delighted it when young.

Let us now examine the work of Phanæus Milo 


\section{THE LIFE AND LOVE OF THE INSECT}
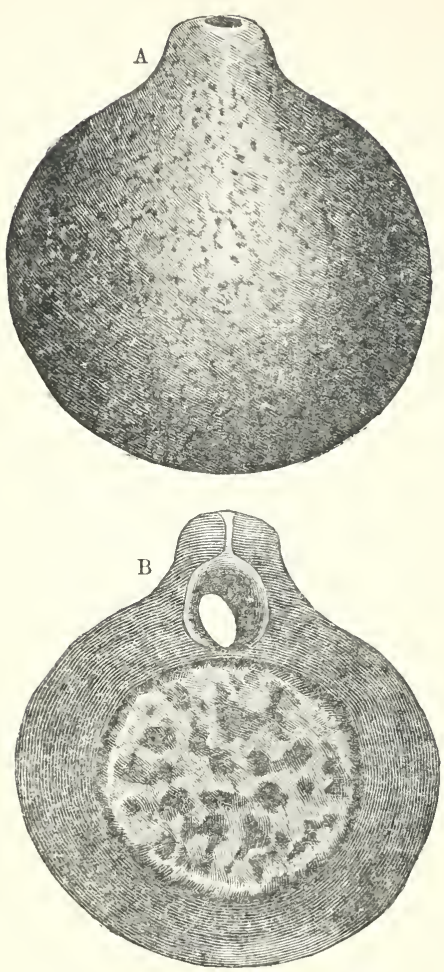

Frg. 9.-Work of Phanæus Milo.

$A$, the whole piece, actual size. B, the same opened, showing the pill of sausage-meat, the clay gourd, the chamber containing the egrg and the ventilating-shaft. more thoroughly. The calabashes came into my hands in a state of complete desiccation. They are very nearly as hard as stone; their colour favours a pale chocolate. Neither inside nor out does the lens discover the small fibrous particle pointing to a residuum of grasses. The strange Dung-beetle does not, therefore, employ the bovine cakes, nor anything similar; he handles products of another class, which are pretty difficult to specify at first.

Held to the ear and shaken, the object sounds a little as would the shell of a dry fruit with a stone lying free inside it. Does it contain the grub, shrivelled by desiccation? Does it contain the dead insect? I thought so, 
but I was wrong. It contains something much better than that for our instruction.

I carefully rip up the gourd with the point of the knife. Under a homogeneous outer wall, the thickness of which reaches as much as two centimetres ${ }^{1}$ in the largest of my three specimens, is encased a spherical kernel, which fills the cavity exactly, but without sticking to the wall at any part. The trifle of free scope allowed to this kernel accounts for the rattling which I heard when shaking the piece.

The kernel does not differ from the wrapper in the colour and general appearance of its bulk. But let us break it and examine the shreds. I recognize tiny fragments of gold, flocks of down, threads of wool, scraps of meat, the whole drowned in an earthy paste resembling chocolate.

Placed on a glowing coal, this paste, shredded under the lens and deprived of its particles of dead bodies, becomes much darker, is covered with shiny bubbles and sends forth puffs of that acrid smoke in which we easily recognize burnt animal matter. The whole mass of the kernel, therefore, is strongly impregnated with sanies.

Treated in the same manner, the wrapper also turns dark, but not to the same extent; it hardly smokes ; it is not covered with jet-black bubbles; lastly, it does not anywhere contain shreds of carcasses similar to those in the central nut. In both cases, the residuum of the calcination is a fine, reddish clay.

This brief analysis tells us all about Phanæus Milo's table. The fare served to the grub is a sort of vol-auvent. The sausage-meat consists of a mince of all that the two scalpels of the shield and the toothed knives of the fore-legs have been able to cut away from the carcass :

1 '78 inch.-Translator's Note. 
hair and down, crushed ossicles, strips of flesh and skin. Now hard as brick, the thickening of that mince was originally a jelly of fine clay soaked in the juice of corruption. Lastly, the puff-paste crust of our vol-au-vent is here represented by a covering of the same clay, less rich in extract of meat than the other.

The pastry-cook gives his pie an elegant shape; he decorates it with rosettes, with twists, with scrolls. Phanæus Milo is no stranger to these culinary æsthetics. He turns the crust of his vol-au-vent into a handsome gourd, ornamented with a finger-print guilloche.

The outer covering, a disagreeable crust, insufficiently steeped in savoury juices, is not, we can easily guess, intended for consumption. It is possible that, somewhat later, when the stomach becomes robust and is not repelled by coarse fare, the grub scrapes a little from the wall of its pie; but, taken as a whole, until the adult insect emerges, the calabash remains intact, having acted as a safeguard of the freshness of the mince-meat at first and as a protecting box for the recluse from start to finish.

Above the cold pasty, right at the base of the neck of the gourd, is contrived a round cell with a clay wall continuing the general wall. A fairly thick floor, made of the same material, separates it from the store-room. It is the hatching-chamber. Here is laid the egg, which I find in its place, but dried up; here is hatched the worm, which, to reach the nourishing ball, must previously open a trap-door through the partition separating the two storeys.

The worm is born in a little box surmounting the nourishing pile, but not communicating with it. The budding grub must, therefore, at the opportune moment, itself pierce the covering of the pot of preserves. As a 
matter of fact, later, when the worm is on the sausagemeat, we find the floor perforated with a hole just large enough for it to pass through.

Wrapped all round in a thick casing of pottery, the meat keeps fresh as long as is required by the duration of the hatching-process, a detail which I have not ascertained; in its cell, which is also of clay, the egg lies safe. Capital: so far, all is well. Phanæus Milo is thoroughly acquainted with the mysteries of fortification and the danger of victuals evaporating too soon. There remain the breathing requirements of the germ.

To satisfy these, the insect has been equally wellinspired. The neck of the calabash is pierced, in the direction of its axis, with a tiny channel which would admit at most the thinnest of straws. Inside, this conduit opens at the top of the dome of the hatchingchamber; outside, at the tip of the nipple, it spreads into a wide mouth-piece. This is the ventilating-shaft, protected against intruders by its extreme narrowness and by grains of dust which obstruct it a little, without stopping it up. It is simply marvellous, I said. Was I wrong? If a construction of this sort is a fortuitous result, we must admit that blind chance is gifted with extraordinary foresight.

How does the awkward insect manage to carry so delicate and complex a piece of building through? Exploring the pampas as I do through the eyes of an intermediary, my only guide in this question is the structure of the work, a structure whence we can deduct the workman's methods without going far wrong. I therefore imagine the labour to proceed like this : a small carcass is found, the oozing of which has softened the underlying loam. The insect collects more or less of this loam, 


\section{THE LIFE AND LOVE OF THE INSECT}

according to the richness of the vein. There are no precise limits here. If the plastic material abound, the collector is lavish with it and the provision-box becomes all the more solid. Then enormous calabashes are ob-

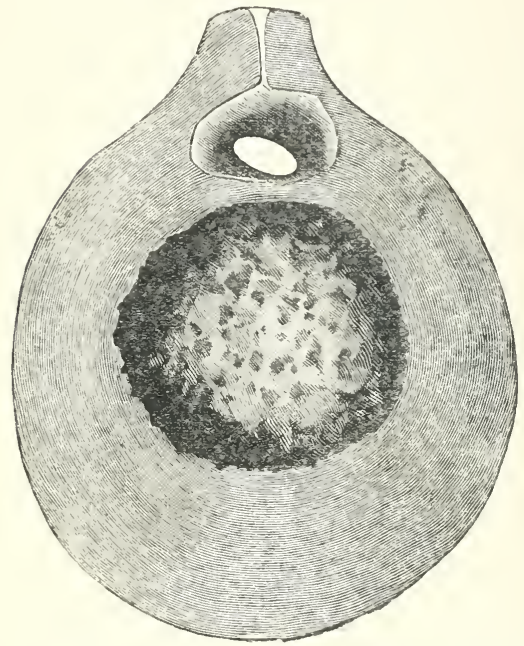

FIG 10.-Work of Phanæus Milo: the largest of the gourds observed (natural size). tained, exceeding a hen's egg in volume and formed of an outer wall a couple of centimetres thick. ${ }^{1}$ But a mass of this description is beyond the strength of the modeller, is badly handled and betrays, in its outline, the clumsiness of an over-difficult task. If the material be rare, the inseot confines its harvesting to what is strictly necessary; and then, freer in its movements, it obtains a magnificently regular gourd.

The loam is probably first kneaded into a ball and then scooped out into a large and very thick cup, by means of the pressure of the fore-legs and the work of the shield.

$1 \cdot 78$ inch.-Translator's Note. 
Even thus do the Copris and the Sacred Beetle act when preparing, on the top of their round ball, the bowl in which the egg will be laid before the final manipulation of the ovoid or pear.

In this first business, Phanæus is simply a potter. So long as it be plastic, any clay serves his turn, however meagrely it be saturated with the juices emanating from the carcass.

He now becomes a pork-butcher. With his toothed knife, he carves, he saws some tiny shreds from the rotten animal; he tears off, cuts away what he deems best suited to the grub's entertainment. He collects all these fragments and mixes them with choice loam in the spots where the sanies abounds. The whole, cunningly kneaded and softened, becomes a ball obtained on the spot, without any rolling process, in the same way as the globe of the other pill-manufacturers. Let us add that this ball, a ration calculated by the needs of the grub, is very nearly constant in size, whatever the thickness of the final calabash. The sausage-meat is now ready. It is set in place in the wide-open clay bowl. Loosely packed, without compression, the food will remain free, will not stick to its wrapper.

Next, the potter's work is renewed. The insect presses the thick lips of the clayey cup, rolls them out and applies them to the forcemeat preparation, which is eventually contained by a thin partition ai the top and by a thick layer every elsewhere. A large circular pad is left on the top partition, which is slender in view of the weakness of the grub that is to perforate it later, when making for the provisions. Manipulated in its turn, this pad is converted into a hemispherical hollow, in which the egg is forthwith laid. 


\section{TIIE LIFE AND LOVE OF THE INSECT}

The work is finished by rolling out and joining the edges of the little erater, which eloses and becomes the hatehing-chamber. Here, especially, a delicate dexterity becomes essential. At the time that the nipple of the calabash is being shaped, the insect, while packing the material. must leave the little ehannel which is to form the ventilating-shaft, following the line of the axis. This narrow conduit, which an ill-ealculated pressure might stop up beyond hope of remedy, seems to me extremely difficult to obtain. The most skilful of our potters could not manage it without the aid of a needle, which he would afterwards withdraw. The insect, a sort of jointed automaton, obtains its ehannel through the massive nipple of the gourd without so much as a thought. If it did give it a thought, it would not suceeed.

The calabash is made: there remains the deeoration. This is the work of patient after-touches which perfect the eurves and leave on the soft loam a series of stippled impressions similar to those which the potter of prehistorie days distributed with the end of his thumb over his big-bellied jars.

That ends the work. The inseet will begin all over again under a fresh eareass; for each burrow has one calabash and no more, even as with the Saered Beetle and her pears. 


\section{'THE GEO'TRUPES}





\section{CHAPTER IX}

THE GEOTRUPES: THE PUBLIC HEALTH

To complete the cycle of the year in the full-grown form, to see one's self surrounded by one's sons at the spring festivals, to double and treble one's family: that surely is a most exceptional privilege in the insect world. The Apids, the aristocracy of instinct, perish, once the honeypot is filled; the Butterflies, the aristocracy not of instinct, but of dress, die when they have fastened their packet of eggs in a propitious spot; the Carabids, richly cuirassed, succumb when the germs of a posterity are scattered beneath the stones.

So with the others, except among the gregarious insects, where the mother survives, either alone or accompanied by her attendants. It is a general law : the insect is born orphaned of both its parents. Now, by an unexpected turn of fate, the humble scavenger escapes the stern destiny that cuts down the proud. The Dung-beetle, sated with days, becomes a patriarch and really deserves to do so, in consideration of the services rendered.

There is a general hygiene that calls for the disappearance, in the shortest possible time, of every putrid thing. Paris has not yet solved the formidable problem of her refuse, which sooner or later will become a question of life or death for the monstrous city. One asks one's self whether the centre of light be not doomed to be extin- 


\section{THE LIFE AND LOVE OF THE INSECT}

guished one day in the reeking exhalations of a soil saturated with rottenness. What this agglomeration of millions of men cannot obtain, with all its treasures of wealth and talent, the smallest hamlet possesses without going to any expense or even troubling to think about it.

Nature, so lavish of her cares in respect of rural health, is indifferent to the welfare of cities, if not actively hostile to it. She has created for the fields two elasses of scavengers, whom nothing wearies, whom nothing repels. One of these-consisting of Flies, Silphids, Dermestes, Necrophores-is charged with the dissection of corpses. They cut and hash, they elaborate the waste matter of death in their stomachs in order to restore it to life.

A mole ripped open by the plough-share soils the path with its entrails, which soon turn purple; a snake lies on the grass, crushed by the foot of a wayfarer who thought, the fool, that he was performing a good work; an unfledged bird, fallen from its nest, has flattened itself piteously at the foot of the tree that carried it ; thousands of other similar remains, of every sort and kind, are scattered here and there, threatening danger through their effluvia, if nothing eome to establish order. Have no fear : no sooner is a corpse signalled in any direction than the little undertakers come trotting along. They work away at it, empty it, consume it to the bone, or at least reduce it to the dryness of a mummy. In less than twenty-four hours, mole, snake, bird have disappeared and the requirements of health are satisfied.

The same zeal for their task prevails in the second class of scavengers. The village hardly knows those ammoniascented refuges whither we repair, in the towns, to relicre our wretched needs. A little wall no higher than that, a hedge, a bush is all that the peasant asks 
as a retreat at the moment when he would fain be alone. I need say no more to suggest the encounters to which such free and easy manners expose you! Enticed by the patches of lichen, the cushions of moss, the tufts of homewort and other pretty things that adorn old stones, you go up to a sort of wall that supports the ground of a vineyard. Ugh! At the foot of the daintily-decked shelter, what a spreading abomination! You flee: lichens, mosses and homewort tempt you no more. But come back on the morrow. The thing has disappeared, the place is clean : the Dung-beetles have been that way.

To preserve the eyes from offensive sights too oft repeated is, to those gallant fellows, the least of offices : a loftier mission is incumbent on them. Science tells us that the most dreadful scourges of mankind have their agents in tiny organisms, the microbes, near neighbours of must and mould, on the extreme confines of the vegetable kingdom. The terrible germs multiply by countless myriads in the intestinal discharges at times of epidemic. They contaminate the air and water, those primary necessities of life; they spread over our linen, our clothes, our food and thus diffuse contagion. WV have to destroy by fire, to sterilize with corrosives or to bury underground such things as are soiled with them.

Prudence even demands that we should never allow ordure to linger on the surface of the ground. It may be harmless, it may be dangerous : when in doubt, the best thing is to put it out of sight. That is how ancient wisdom seems to have understood the thing, long before the microbe explained to us the great need for vigilance. The nations of the East, more exposed to epidemics than ourselves, had formal laws in these matters. Moses, apparently echoing Egyptian knowledge in this connec- 


\section{THE LIFE AND LOVE OF THE INSECT}

tion, prescribed the line of conduct for his people wandering in the Arabian desert :

"Thou shalt have a place without the camp," he says, "to which thou mayst go for the necessities of nature, carrying a paddle at thy girdle. And, when thou sittest down, thou shalt dig round about and, with the earth that is dug up, thou shalt cover that which thou art eased of." (Deut., XXIII., xii-xiv.)

This is a precept of grave import in its simplicity. And we may well believe that, if Islamism, at the time of its great pilgrimages to the Kaaba, were to take the same precaution and a few more of a similar character, Mecca would cease to be an annual seat of cholera and Europe would not need to mount guard on the shores of the Red Sea to protect herself against the scourge.

Heedless of hygiene as the Arab, who was one of his ancestors, the Provençal peasant does not suspect the danger. Fortunately, the Dung-beetle, that faithful observer of the Mosaic edict, works. It is his to remove from sight, it is his to bury the germ-crammed matter.

Supplied with implements for digging far superior to the paddle which the Israelite was to carry at his girdle when urgent business called him from the camp, he hastens and, as soon as man is gone, digs a pit wherein the infection is swallowed up and rendered harmless.

The services rendered by these diggers are of the highest importance to the health of the fields; yet we, who are mainly interested in this constant work of purification, hardly vouchsafe those sturdy fellows a contemptuous glance. Popular language overwhelms them with obnoxious epithets. This appears to be the 
rule : do good and you shall be misjudged, you shall be traduced, stoned, trodden underfoot, as witness the toad, the bat, the hedgehog, the owl and other auxiliaries who, to serve us, ask nothing but a little tolerance.

Now, of our defenders against the dangers of filth spread shamelessly in the rays of the sun, the most remarkable, in our climes, are the Geotrupes : not that they are more zealous than the others, but because their size makes them capable of bigger work. Moreover, when it becomes simply a question of their nourishment, they resort by preference to the materials which we have most to fear.

My neighbourhood is worked by four Geotrupes. Two of them, Geotrupes Mutator (Marsh) and Geotrupes Sylvaticus (Panz.), are rarities on which we had best not count for connected studies; the two others, on the contrary, Geotrupes Stercorarius (Lin.) and Geotrupes Hypocrita (Schneid.), are exceedingly frequent. Black as ink above, both of them are magnificently garbed below. One is quite surprised to find such a jewel-case among the professional scavengers. Geotrupes Stercorarius is of a splendid amethyst violet on his lower surface, while Geotrupes Hypocrita is lavish with the ruddy gleams of copper pyrites. These are the two inmates of my voleries.

Let us ask them first of what feats they are capable as buriers. There are a dozen, of the two species taken together. The cage is previously swept clean of what remains of the former provisions, hitherto supplied without stint. This time, I propose to arrive at what a Geotrupe can put away at a sitting. At sunset, I serve to my twelve captives the whole of a heap which a mule has just dropped in front of my door. There is plenty of it, enough to fill a basket. 


\section{THE LIFE AND LOVE OF THE INSECT}

On the morning of the next day, the mass has disappeared underground. There is nothing left outside, or very nearly nothing. I am able to make a fairly close estimate and I find that each of my Geotrupes, presuming each of the twelve to have done an equal share of the work, has stowed away very nearly a cubic decimetre ${ }^{1}$ of matter. A Titanic task, if we remember the insignificant size of the animal, which, moreover, has to dig the warehouse to which the booty must be lowered. And all this is done in the space of a night.

So well provided, will they remain quietly underground with their treasure? Not they! The weather is magnificent. The hour of twilight comes, gentle and calm. This is the time of the great flights, the mirthful hummings, the distant explorations on the roads by which the herds have lately passed. My lodgers abandon their cellars and mount to the surface. I hear them buzzing, climbing up the wirework, knocking themselves wildly against the walls. I have anticipated this twilight animation. Provisions have been collected during the day, plentiful as those of yesterday. I serve them. There is the same disappearance during the night. On the morrow, the place is once again swept clean. And this would continue indefinitely, so fine are the evenings, if I always had at my disposal the wherewithal to satisfy those insatiable hoarders.

Rich though his booty be, the Geotrupe leaves it at sunset to sport in the last gleams of daylight and to go in search of a new workplace. With him, one would say, the wealth acquired does not count; the only valid thing is that to be acquired. Then what does he do with his warehouses, renewed, in favourable times, at 1 About 61 cubic inches.-Translator's Note. 
each new twilight? It is obvious that Stercorarius is incapable of consuming provisions so plentiful in a single night. He has such a superabundance of victuals in his larder that he does not know how to dispose of them; he is surfeited with good things by which he will not profit; and, not satisfied with having his store crammed, the acquisitive plutocrat slaves, night after night, to store away more.

From each warehouse, set up here, set up there, as things happen, he deducts the daily meal beforehand; the rest, that is to say, almost the whole, he abandons. My voleries testify to the fact that this instinct for burying is more exacting than the consumer's appetite. The ground is soon raised, in consequence; and I am obliged, from time to time, to lower the level to the desired limits. If I dig it up, I find it choked, throughout its depth, with hoards that have remained intact. The original earth has become an inextricable conglomerate, which I must prune with a free hand, if I would not go astray in my future observations.

Allowing for errors, either of excess or deficiency, which are inevitable in a subject that does not admit of precise gauging, one point stands out very clearly from my enquiry : the Geotrupes are passionate buriers ; they take underground a deal more than is necessary for their consumption. As this work is performed, in varying degrees, by legions of collaborators, large and small, it is evident that the purification of the soil must benefit by it to an ample extent and that the public health is to be congratulated on having this army of auxiliaries in its service.

In other respects, the plant and, indirectly, a host of different existences are interested in these interments. What the Geotrupe buries and abandons the next day 


\section{THE LIFE AND LOVE OF THE INSECT}

is not lost : far from it. Nothing is lost in the world's balance-sheet; the stock-taking total is constant. The little lump of dung buried by the insect will make the nearest tuft of grass grow a luxuriant green. A sheep passes, crops the bunch of grass: all the better for the leg of mutton which man is waiting for. The Dungbeetle's industry has procured us a savoury mouthful.

In September and October, when the first autumn rains soak the ground and allow the Sacred Beetle to split his natal easket, Geotrupes Stercorarius and Geotrupes Hypocrita found their family-establishments, somewhat makeshift establishments, in spite of what we might have expected from the name of those miners, so well-styled Geotrupes, that is to say, "Earth-borers." When he has to dig himself a retreat that shall shelter him against the rigours of winter, the Geotrupe really deserves his name: none can compare with him for the depth of the pit or the perfection and rapidity of the work. In sandy ground, easily excavated, I have dug up some that had attained the depth of a metre. ${ }^{1}$ Others carried their digging further still, tiring both my patience and my implements. There you have the skilled well-sinker, the incomparable Earth-borer. When the cold sets in, he can go down to some layer where frost has lost its terrors.

The lodging of the family is another matter. The propitious season is a short one; time would fail, if each individual grub had to be endowed with one of those manor-houses. That the insect should devote the leisure which the approach of winter gives it to digging a hole of unlimited depth is a capital thing: it makes the retreat doubly safe; and activity, not yet quite sus1 Over 39 inches.-Translator's Note. 
(1)

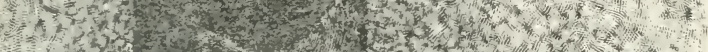

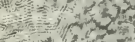

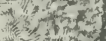

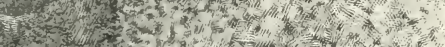

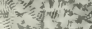

H

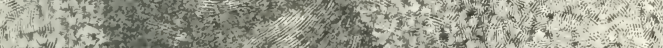

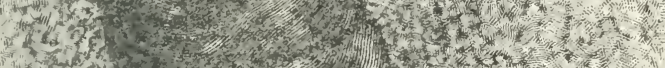

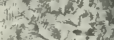

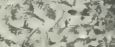

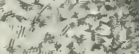

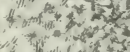

(e)

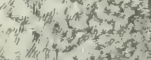

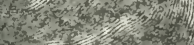

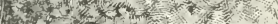

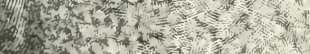

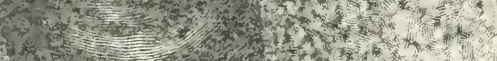

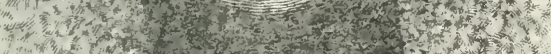

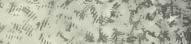

nots

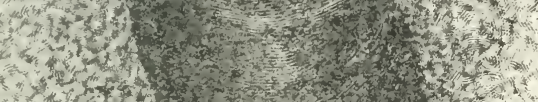

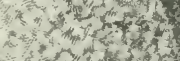

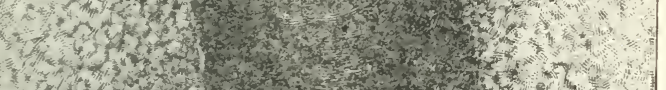

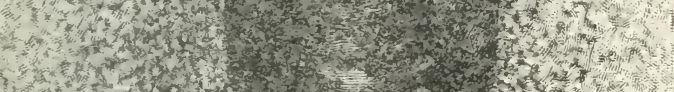

(1)

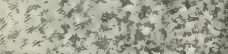

wh

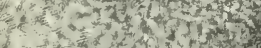

S. $3=0$.

1.

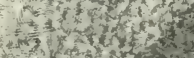

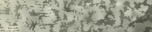

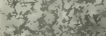

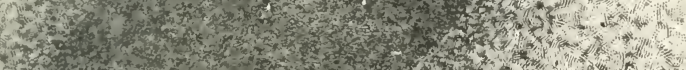

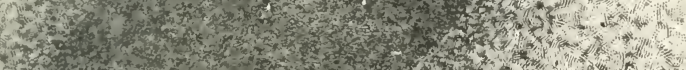

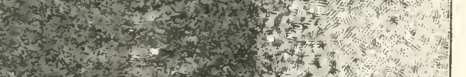
ก.

단

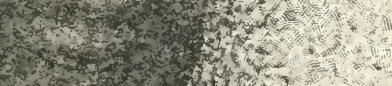

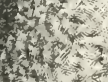

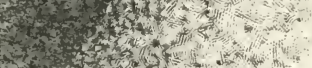
s.

Wint in

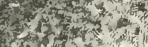

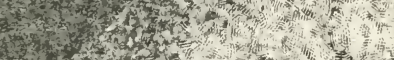

車

造

空

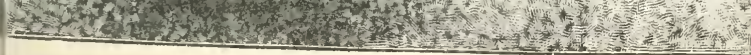




\section{THE LIFE AND LOVE OF THE INSECT}

pended, has for the moment no other occupation. But, at laying-time, these laborious undertakings are impossible. The hours pass swiftly. In four or five weeks, a pretty numerous family has to be housed and victualled, which puts a long, patiently-sunk pit entirely out of the question.

The burrow dug by the Geotrupe for the benefit of her

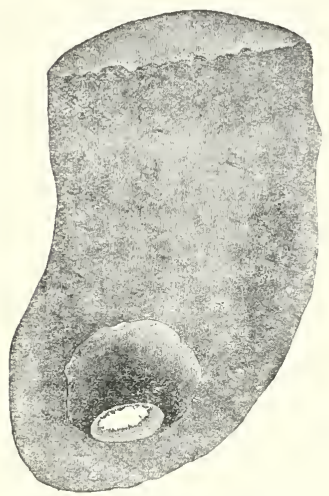

FIG, 12.-Section of the Stercoraceous Geotrupe's sausage at its lower end, showing the erg and the hatching-chamber. grub is hardly deeper than that of the Copris or the Sacred Beetle, notwithstanding the difference of the seasons. Three decimetres, ${ }^{1}$ roughly speaking: that is all that I find in the fields, where nothing occurs to limit the depth.

The contents of the rustic dwelling take the form of a sort of sausage or pudding, which fills the lower part of the cylinder and fits it exactly. Its length is not far short of a couple of decimetres. ${ }^{2}$ This sausage is almost always irregular in shape, now curved, now more or less dented. These imperfections of the surface are due to the accidents of a stony ground, which the insect does not always excavate according to the canons of its art, which favours the straight line and the perpendicular. The moulded material faithfully reproduces all the irregularities of its

111 to 12 inches. - Translator's Note.

2 $7 \frac{1}{2}$ to 8 inches.-Translator's Note. 
mould. The lower extremity is rounded off like the bottom of the burrow itself; at the lower end of the sausage is the hatching-chamber, a round cavity which could hold a fair-sized hazel-nut. The respiratory needs of the germ demand that the side-walls should be thin enough to allow easy access to the air. Inside, I catch the gleam of a greenish, semi-fluid plaster, a dainty which the mother has disgorged to form the first mouthfuls of the budding worm.

In this round hole lies the egg, without adhering in any way to the surrounding walls. It is a white, elongated ellipsoid and is of remarkable bulk in proportion to the insect. In the case of Geotrupes Stercorarius, it measures seven to eight millimetres in length by four in its greatest width. ${ }^{1}$ The egg of Geotrupes Hypocrita is a little smaller.

$1 \cdot 27$ to $\cdot 31 \times \cdot 15$ inch. - Translalor's Note. 




\section{CHAPTER X}

\section{MINOTAURUS TYPHEUS}

To describe the insect that forms the subject of this chapter, scientific nomenclature joins two formidable names : that of the Minotaur, Minos' bull fed on human flesh in the crypts of the Cretan labyrinth; and that of Typhœus, one of the giants, sons of Terra, who tried to scale the heavens. Thanks to the clue of thread which he received from Minos' daughter Ariadne, Theseus the Athenian found the Minotaur, slew him and made his escape, safe and sound, after delivering his country for ever from the dreadful tribute destined for the monster's food.

Typhœus, struck by a thunderbolt on his heaped-up mountains, was hurled under Mount Etraa. He is there still. His breath is the smoke of the volcano. When he coughs, he spits out streams of lava; when he shifts his position from one shoulder to the other, he puts Sicily aflutter; he shakes her with an earthquake.

It is not unpleasant to find an echo of these old fables in the history of animals. Mythological denominations, so resonant and pleasing to the ear, entail no inconsistencies with reality, a fault that is not always avoided by the terms compiled wholly of data gathered from the lexicon. When vague analogies, in addition, connect the fabled with the historical, then surnames and fore- 
names both become very happy. Such is the case with Minotaurus Typhœus (Lin.).

It is the name given to a fair-sized black coleopteron, closely related to the Earth-borers, the Geotrupes. He is a peaceable, inoffensive creature, but even better-horned than Minos' bull. None among our harness-loving insects wears so threatening an armour. The male carries on his corselet a sheaf consisting of three steeled spears, parallel to one another and jutting forward. Imagine him the size of a bull; and Theseus himself, if he met him in the fields, would hardly dare to face his terrible trident.

The Typhœus of the legend had the ambition to sack the home of the gods by stacking one upon the other a pile of mountains torn from their base; the Typhœus of the naturalists does not climb: he descends; he bores the ground to enormous depths. The firsis, with a movement of the shoulder, sets a province heaving; the second, with a thrust of its chine, makes his mole-hill tremble as Etna trembles when he stirs who lies buried within her depths.

Such is the insect wherewith we are concerned.

But what is the use of this history, what the use of all this minute research? I well know that it will not produce a fall in the price of pepper, a rise in that of crates of rotten cabbages, or other serious events of this kind, which cause fleets to be manned and set people face to face intent upon one another's extermination. The insect does not aim at so much glory. It confines itself to showing us life in the inexhaustible variety of its manifestations; it helps us to decipher in some small measure the obscurest book of all, the book of ourselves.

The insect is easy to obtain, cheap to feed and not repulsive to examine organically; and it lends itself far 
better than the higher animals to the investigations of our curiosity. Besides, the others are our near neighbours and do but repeat a somewhat monotonous theme, whereas the insect, with its unparalleled wealth of instincts, habits and structure, reveals a new world to us, much as though we were conferring with the natives of another planet. This is the reason that makes me constantly renew my unwearied relations with the insect and hold it in such high esteem.

Minotaurus Typhœus favours the open sandy places where, on their way to the grazing-ground, the flocks of sheep scatter their trails of black pellets which constitute his regulation fare. Couples jointly addicted to nestbuilding begin to meet in the first days of Narch. The two sexes, until then isolated in surface-burrows, are now associated for a long time to come.

Do the husband and wife recognize each other among their fellows? Are they mutually faithful? Cases of breach of matrimony are very rare, in fact unknown, on the part of the mother, who has long ceased to leave the house; on the other hand, they are frequent on the part of the father, whose duties often oblige him to come outside. As will be seen presently, he is, throughout his life, the purveyor of victuals and the person entrusted with the carriage of the rubbish. Alone, at different hours of the day, he flings out of doors the earth thrown up by the mother's excavations; alone he explores the vicinity of the home at night, in quest of the pellets whereof his sons' loaves shall be kneaded.

Sometimes, two burrows are side by side. Cannot the collector of provisions, on returning home, easily mistake the door and enter another's house? On his walks abroad, does he never happen to meet ladies taking the 
air who have not yet settled down; and is he, then, not forgetful of his first mate and ready for divorce? The question deserved to be examined. I tried to solve it in the manner that follows.

Two couples are taken from the ground at a time when the excavations are in full swing. Indelible marks, contrived with the point of a needle on the lower edge of the elytra, will enable me to distinguish them one from the other. The four subjects of my experiment are distributed at random, one by one, over the surface of a sandy area a couple of spans thick. A soil of this depth will be sufficient for the excavations of a night. In case provisions should be needed, a handful of sheep-droppings is served. A large reversed earthen pan covers the arena, prevents escape and produces the darkness farourable to mental concentration.

The next morning provides a splendid response. There are two burrows in the establishment, no more; the couples have formed again as they were : each Jack has his Jill. A second experiment, made next day, and a third meet with the same success : those marked with a point are together, those not marked are together, at the bottom of the gallery.

Five times more, day after day, I make them set up house anew. Things now begin to be spoilt. Sometimes, each of the four that are being experimented on settles apart; sometimes, the same burrow contains the two males or the two females; sometimes, the same crypt receives the two sexes, but differently associated from what they were at the start. I have abused my powers of repetition. Henceforth disorder reigns. MIy daily shufflings have demoralized the burrowers; a crumbling home, always requiring to be begun afresh, has put an 
end to lawful associations. Respectable married life becomes impossible from the moment when the house falls in from day to day.

No matter: the first three experiments, made when alarms, time after time repeated, had not yet tangled the delicate connecting thread, seem to point to a certain constancy in the Minotaurus household. He and she know each other, find each other in the tumult of events which my mischievous doings force upon them; they show each other a mutual fidelity, a very unusual quality in the insect class, which is but too prone to forget its matrimonial obligations.

We recognize one another by our speech, by the sound, the inflection of our voices. They, on the other hand, are dumb, deprived of all means of vocal appeal. There remains the sense of smell. Minotaurus finding his mate makes me think of my friend Tom, the house-dog, who, at his moony periods, lifts his nose in the air, sniffs the breeze and jumps over the garden-walls, eager to obey the distant and magical convocation ; he puts me in mind of the Great Peacock Moth, who swiftly covers several miles to pay his homage to the new-hatched maid.

The comparison, however, is far from perfect. The dog and the big Moth get wind of the wedding before they know the bride. Minotaurus, on the other hand, has no experience of long pilgrimages, yet makes his way, in a brief circuit, to her whom he has already visited; he knows her, he distinguishes her from the others by certain emanations, certain individual scents inappreciable to any save the enamoured swain. Of what do these effluvia consist? The insect did not tell me ; and that is a pity, for it would have taught us things worth knowing about its feats of smell. 


\section{THE LIFE AND LOVE OF THE INSECT}

Now how is the work divided in this household? To discover this is not one of those easy undertakings for which the point of a knife suffices. He who proposes to visit the burrowing insect at home must have recourse to arduous sapping. We have here to do not with the apartment of the Sacred Beetle, the Copris or the others, which is soon laid bare with a mere pockettrowel: we have to do with a pit the bottom of which can be reached only with a stout spade, sturdily wielded for hours at a stretch. And, if the sun be at all hot, one returns from the drudgery utterly exhausted.

Oh, my poor joints, grown rusty with age! To suspect the existence of a fine problem underground and not to be able to dig! The zeal survives, as ardent as in the days when I used to pull down the spongy slopes beloved by the Anthophora; the love of research has not abated, but the strength is lacking. Luckily, I have an assistant, in the shape of my son Paul, who lends me the vigour of his wrists and the suppleness of his loins. I am the head, he is the arm.

The rest of the family, including the mother-and she not the least eager-usually go with us. One cannot have too many eyes when the pit becomes deep and one has to observe from a distance the minute documents exhumed by the spade. What the one misses the other perceives. Huber, ${ }^{1}$ when he went blind, studied the bee through the intermediary of a clear-sighted and devoted adjutrix. I am even better-off than the great Swiss naturalist. My sight, which is still fairly good, although exceedingly tired, is aided by the deep-seeing eyes of all

1 François Huber (1750-1831), the Swiss naturalist. He early became blind from excessive study and conducted his scientific work thereafter with the aid of his wife.-Translator's Note. 


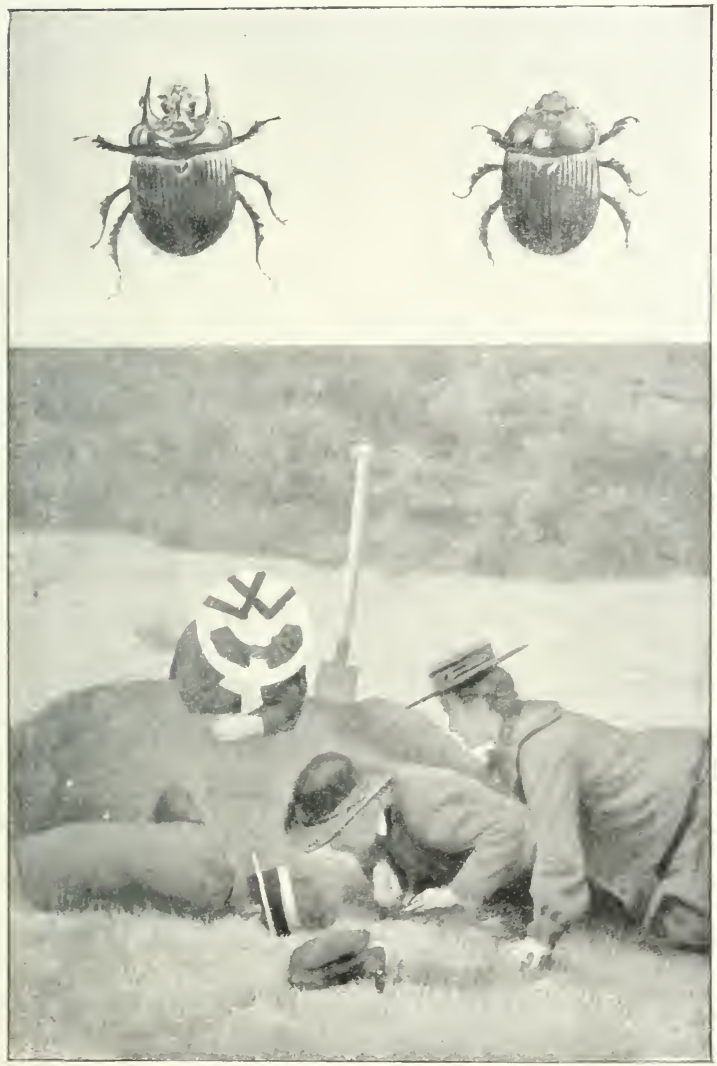

Minotaurus Typhous, male and female. Excavating Minotaurus' burow. 

my family. I owe to them the fact that I am able to pursue my researches : let me thank them here.

We are on the spot early in the morning. We soon find a burrow with a large mole-hill formed of cylindrical stoppers forced out in one lump by blows of the rammer. We clear away the mound and a pit of great depth opens below it. A useful reed, gathered on the way, serves me as a guide, diving lower and lower down. At last, at about five feet, the reed touches bottom. We are there, we have reached Minotaurus' chamber.

The pocket-trowel prudently lays things bare and we see the occupants appear: the male first and, a little lower, the female. When the couple are removed, a dark, circular patch shows : this is the end of the column of victuals. Careful now and let us dig gently! What we have to do is to cut away the central clod at the bottom of the vat, to isolate it from the surrounding earth and then, slipping the trowel underneath and using it as a lever, to extract the block all in a lump. There! That's done it! We possess the couple and their nest. A morning of arduous digging has procured us those treasures : Paul's steaming back could tell us at the price of what efforts.

This depth of five feet is not and could not be constant; numbers of causes induce it to vary, such as the degree of freshness and consistency of the soil traversed, the insect's passion for work and the time available, according to the more or less remote date of the laying. I have seen burrows go a little lower; I have seen others reach barely three feet. In any case, Minotaurus, to settle his family, requires a lodging of exaggerated depth, such as is dug by no other burrowing insect of my acquaintance. Presently we shall have to ask ourselves what are the 


\section{THE LIFE AND LOVE OF THE INSECT}

imperious needs that oblige the collector of sheep. droppings to reside so low down in the earth.

Before leaving the spot, let us note a fact the evidence of which will be of value later. The female was right at the bottom of the burrow ; above her, at some distance, was the male: both were struck motionless with fright in the midst of an occupation the nature whereof we are not yet able to specify. This detail, observed repeatedly in the different burrows excavated, seems to show that each of the two fellow-workers has a fixed place.

The mother, more skilled in nursery matters, occupies the lower floor. She alone digs, versed as she is in the properties of the perpendicular, which economizes work while giving the greatest depth. She is the engineer, always in touch with the working-face of the gallery. The other is her journeyman-mason. $\mathrm{He}$ is stationed at the back, ready to load the rubbish on his horny hod. Later, the excavatrix becomes a baker : she kneads the cakes for the children into cylinders ; the father is then her baker's boy. He fetches her from outside the wherewithal for making flour. As in every well-regulated household, the mother is minister of the interior, the father minister of the exterior. This would explain their invariable position in the tubular home. The future will tell us if these conjectures represent the reality as it is.

For the moment, let us make ourselves at home and examine at leisure the central clod so laboriously acquired. It contains preserved foodstuffs in the shape of a sausage nearly as long and thick as one's finger. This is composed of a dark, compact matter, arranged in layers, which we recognize as the sheep-pellets reduced to morsels. Sometimes, the dough is fine and almost homogeneous from one end of the cylinder to the other; more often, the 
piece is a sort of hardbake, in which large fragments are held together by a cement of amalgam. The baker apparently varies the more or less finished confection of her pastry according to the time at her disposal.

The thing is closely moulded in the terminal pocket of the burrow, where the walls are smoother and more carefully fashioned than in the rest of the pit. The point of the knife easily strips it of the surrounding earth, which peels like a rind or bark. In this way, I obtain the food-cylinder free of any earthy blemish.

Having done this, let us look into the matter of the egg; for the pastry has certainly been manipulated in view of a grub. Guided by what I learnt some time ago from the Geotrupes, who lodge the egg at the lower end of their pudding, in a special recess contrived in the very heart of the provisions, I expect to find Minotaurus' egg right at the bottom of the sausage. I am ill-informed. The egg sought for is not at the expected end, nor at the other end, nor at any point whatever of the victuals.

A search outside the provisions shows it me at last. It is below the food, in the sand itself, deprived of all the finikin cares dear to mothers. There is here not a smooth-walled cell, such as the delicate epidermis of the new-born grub would seem to call for, but a rough cavity, the result of a mere landslip rather than of maternal industry. The worm is to be hatched in this rude berth, at some distance from its provisions. To reach the food, it will have to demolish and pass through a ceiling of sand some millimetres thick.

With insects held captive in an apparatus of my invention, I have succeeded in tracing the construction of that sausage. The father goes out and selects a pellet whose length is greater than the diameter of the pit. He 


\section{THE LIFE AND LOVE OF THE INSECT}

conveys it to the mouth, either backwards, by dragging it with his forefeet, or straight ahead, by rolling it along with little strokes of his shield. He reaches the edge of the hole. Will he hurl the lump down the precipice with one last push? Not at all : he has plans that are incompatible with a violent fall.

He enters, embracing the pellet with his legs and taking care to introduce it by one end. On reaching a certain distance from the bottom, he has only to slant the piece slightly to make it find a support at its two ends against the walls of the channel: this because of the greater length of its main axis. He thus obtains a sort of temporary flooring suited to receive the burden of two or three pellets. The whole forms the workshop in which the father means to do his task without disturbing the mother, who is fully engaged below. It is the mill whence will be lowered the semolina for making the cakes.

The miller is well-equipped for his work. Look at his trident. On the solid basis of the corselet stand three sharp spears, the two outer ones long, the middle one short, all three pointing forwards. What purpose does this weapon serve? At first sight, one would take it for a masculine decoration, one of so many others, of very varied forms, worn by the corporation of Dung-beetles. Well, it is something more than an ornament : Minotaurus turns his gaud into a tool.

The three unequal points describe a concave arch, wide enough to admit a spherical sheep-dropping. Standing on his imperfect and shaky floor, which demands the employment of his four hind-legs, propped against the walls of the perpendicular channel, how will Minotaurus manage to keep the elusive olive in position and break it up? Let us watch him at work. 



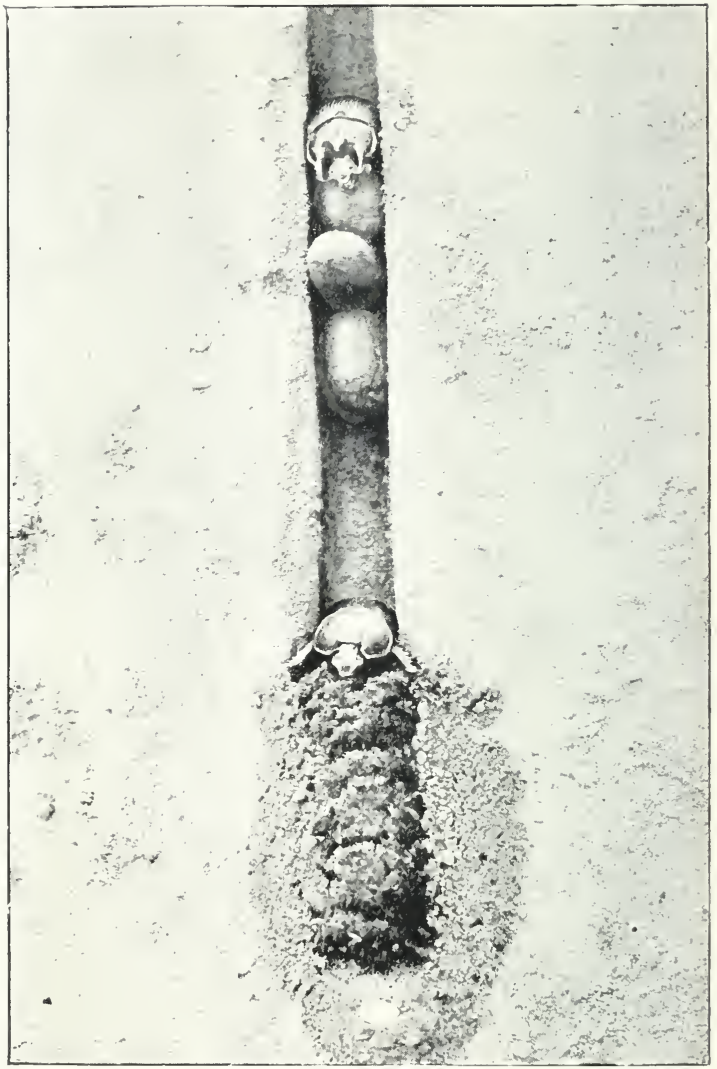

The Minotanrus couple engaged on miller's and baker's work. 
Stooping a little, he digs his fork into the piece, thenceforth rendered stationary, for it is caught between the prongs of the implement. The fore-legs are free; with their toothed armlets they can saw the morsel, lacerate it and reduce it to particles which gradually fall through the crevices of the flooring and reach the mother below.

The substance which the miller sends scooting down is not a flour passed through the bolting-machine, but a coarse grain, a mixture of pulverized remnants and of pieces hardly ground at all. Incomplete though it be, this preliminary trituration is of the grcatest assistance to the mother in her tedious job of bread-making: it shortens the work and allows the best and the middling to be separated straight away. When everything, including the floor itself, is ground to powder, the horned miller returns to the upper air, gathers a fresh harvest and recommences his shredding labours at leisure.

Nor is the baker inactive in her laboratory. She collects the remnants pouring down around her, subdivides them yet further, refines them and makes her selection: this, the tenderer part, for the central crumb; that, tougher, for the crust of the loaf. Turning this way and that, she pats the material with the battledore of her flattened arms; she arranges it in layers, which presently she compresses by stamping on them where they lie, much after the manner of a vine-grower treading his vintage. Rendered firm and compact, the mass will keep better and longer.

After some ten days of this united labour, the couple at last obtain the long, cylindrical loaf. The father has done the grinding, the mother the kneading.

I have even succeded in watching the digging of this very deep burrow, thanks to a complicated series of 


\section{THE LIFE AND LOVE OF THE INSECT}

artifices which it would take too long to set forth here. The mother is at the bottom of the pit: she alone attacks the working-face, she alone digs. The male keeps at the back of his spouse. He gradually collects the rubbish and makes a load of it which he lifts with his threepronged fork and hoists outside with much exhausting labour.

'This is the moment to recapitulate Minotaurus' merits. When the great colds are over, he sets out in quest of a mate, buries himself with her and thenceforth remains faithful to her, despite his frequent excursions out of doors and the meetings to which these are likely to lead. With indefatigable zeal, he assists the burrower, herself destined never to leave her home until the emancipation of the family. For a month and more, he loads the rubbish of the excavation on his forked hod; he hoists it outside and remains ever patient, never disheartened by his arduous feats of climbing. He leaves the comparatively easy work of the excavating rake to the mother and keeps the more troublesome task, the exhausting carriage through a narrow, very high and perpendicular gallery, for himself.

Next, the navvy turns himself into a collector of foodstuffs; he goes after provisions, he gathers the wherewithal for his sons to live upon. To facilitate the work of his mate, who shreds, stratifies and compresses the preserves, he once more changes his trade and becomes a miller. At some distance from the bottom, he bruises and crumbles the matter found hardened by the sun; he makes it into semolina and flour that gradually pour down into the maternal bakery. Lastly, worn out by his efforts, he leaves the house and goes to die outside, at a distance, in the open air. He has gallantly performed his duty as 
a paterfamilias; he has spent himself without stint to secure the prosperity of his kith and kin.

The mother, on her side, allows nothing to divert her from her housekeeping. Throughout her working life, she never leaves her home: domi mansit, as the ancients used to say, speaking of their model matrons; domi mansit, kneading her cylindrical loaves, filling them with an egg, watching them until the exodus arrives. When the day comes for the autumnal merry-makings, she at last returns to the surface, accompanied by the young people, who disperse at will to feast in the regions frequented by the sheep. Thereupon, having nothing left to do, the devoted mother perishes.

Yes, amid the general indifference of fathers for their sons, Minotaurus displays a very remarkable zeal where his family are concerned. Forgetful of himself, refusing to be led away by the delights of spring, when it would be so pleasant to see a little country, to banquet with his fellows, to tease and flirt with his fair neighbours, he sticks to his work underground and wears himself out so as to leave a fortune to his descendants. Here is one who, when he stiffens his legs for the last time, is well entitled to say :

"I have done my duty ; I have worked." 

THE TWO-BANDED SCOIAA 



\section{CHAPTER XI}

THE TWO-BANDED SCOLIA

IF strength were to take precedence of other zoological attributes, the Scoliæ would reign in the first rank, in the order of the Hymenoptera. Some of them can be compared in size with the little orange-crested northern Wren, the Kinglet, who comes down to us, to visit the maggoty buds, at the time of the first autumnal mists. The largest, the most imposing of our sting-carriers, the Humble-bee, the Hornet, cut a poor figure beside certain Scoliæ. Among this group of giants, my region boasts the Common or Garden Scolia (Scolia Hortorum, van der Lind), who exceeds four centimetres ${ }^{1}$ in length and measures ten ${ }^{2}$ from tip to tip of her outstretched wings, and the Hemorrhoidal Scolia (Scolia Hemorrhoïdalis, van der Lind), who vies in dimensions with the Garden Scolia and is distinguished from her, in the main, by the brush of red bristles at the tip of her belly.

A black livery, with broad yellow patches; tough wings amber as an onion-skin and shot with purple reflections; coarse, knotted legs, bristling with rugged hairs; a massive build; a powerful head, helmeted with a hard skull; a stiff and clumsy gait; a short, silent flight, devoid of soaring qualities: this, in few words, describes the

$11 \frac{1}{2}$ inches.-Translator's Note.

24 inches.-Translator's Note. 


\section{THE LIFE AND LOVE OF THE INSECT}

appearance of the female, powerfully equipped for her severe task. That love-lorn idler, the male, is more gracefully horned, more daintily clad, more elegantly shaped, without altogether losing the character of sturdiness which is the predominant feature in his mate.

It is not without qualms that the insect-collector finds himself for the first time in the presence of the Garden Scolia. How is he to capture the commanding brute, how to protect himself against its sting? If the effect of the sting be in proportion to the Hymenopteron's size, then a prick from the Scolia is something to be dreaded. The Hornet, once he lugs out, hurts us atrociously. What, then, would it be like if one were stabbed by this colossus ? The prospect of a swelling the size of your fist and as painful as though it were blistered by a red-hot iron passes through your mind, just as you are about to cast the net. And you refrain. you beat a retreat, only too glad not to have aroused the attention of the dangerous animal.

Yes, I confess to having quailed before my first Scoliæ, eager though I was to enrich my incipient collection with this glorious insect. Smarting recollections left behind by the Wasp and the Hornet had something to say to this excessive prudence. I say excessive, for to-day, taught by long experience, I have got the better of my former fears and, if I see a Scolia resting on a thistle-head, I have no scruples about taking her in the tips of my fingers, with no precaution of any kind, threatening though her aspect be. My pluck is only apparent, as I am pleased to inform the novice at Hymenopteron-hunting. The Scoliæ are very peaceful. Their sting is an implement of work much rather than a weapon of war : they use it to paralyze the prey intended for their family; and only in the last 
extremity do they employ it in their own defence. Moreover, the lack of suppleness in their movements enables one nearly always to avoid the sting ; and, lastly, if one were stung, the pain of the prick is almost insignificant. This absence of a bitter smart in the poison is a pretty constant fact among the game-hunting Hymenoptera, whose weapon is a surgical lancet intended for the most delicate physiological operations.

Among the other Scoliæ of my district, I will mention the middle-sized Two-banded Scolia (Scolia Bifasciata, van der Lind), whom I see yearly, in September, exploiting the manure-heaps of dead leaves arranged, for her benefit, in a corner of my yard. Let us watch her performance comfortably indoors.

After the Cerceris, it is well to study others, hunting an unarmed prey, a prey vulnerable at all points save the skull, but giving only a single prick with the sting. Of these two conditions, the Scoliæ fulfilled one, with their regulation game, the soft grub of Cetonia, Oryctes or Anoxia, according to their species. Did they fulfil the second? I was convinced beforehand, judging from the anatomy of the victims, with its concentrated nervous system, that the sting was unsheathed but once; I even foresaw the point in which the weapon must be thrust.

These were statements dictated by the anatomist's scalpel, without the least direct proof from observed facts. Stratagems accomplished underground escaped the eye and seemed to me bound always to escape it. How, indeed, could one hope that an animal whose art is practised in the darkness of a manure-heap should be persuaded to work in the full light of day ? I did not reckon on it in the least. Nevertheless, for conscience' sake, I tried putting the Scolia in touch with her quarry 


\section{THE LIFE AND LOVE OF THE INSECT}

under glass. And it was well that I did so, for my success was in the inverse ratio to my expectations. Never did beast of prey show greater zeal in attacking under artificial conditions. Every insect experimented upon rewarded me, sooner or later, for my patience. Let us watch Scolia Bifasciata at work, operating on her Cetonia grub.

The captive grub tries to escape its terrible neighbour. Turned over on its back according to its custom, it shuffles along eagerly, going round and round the glass arena. Soon, the Scolia's attention is aroused and is evinced by continual little taps of the tips of its antennæ upon the table, which now represents the customary soil. The Hymenopteron falls upon her prey and attacks the monstrous meal by the hinder end. She climbs upon the Cetonia, using the abdominal extremity as a lever. The assaulted grub does nothing but scud all the faster on its back, without rolling itself into a defensive posture. The Scolia reaches the front part, after falls and accidents that vary greatly, according to the degree of tolerance of the grub, her temporary mount. With her mandibles, she nips a point on the upper surface of the thorax; she places herself across the grub, curves herself into an arch and tries to touch with the point of her belly the region where the sting is to be darted. The arch is a little too short to embrace almost the whole circuit of the corpulent prey, for which reason the efforts and attempts are made over and over again, at great length. The tip of the abdomen makes untold exertions, applies itself here, there and efsewhere and, as yet, stops nowhere. This tenacious searching in itself proves the importance which the paralyzer attaches to the spot at which its bistoury is to enter.

Meanwhile, the grub continues to move along on its 


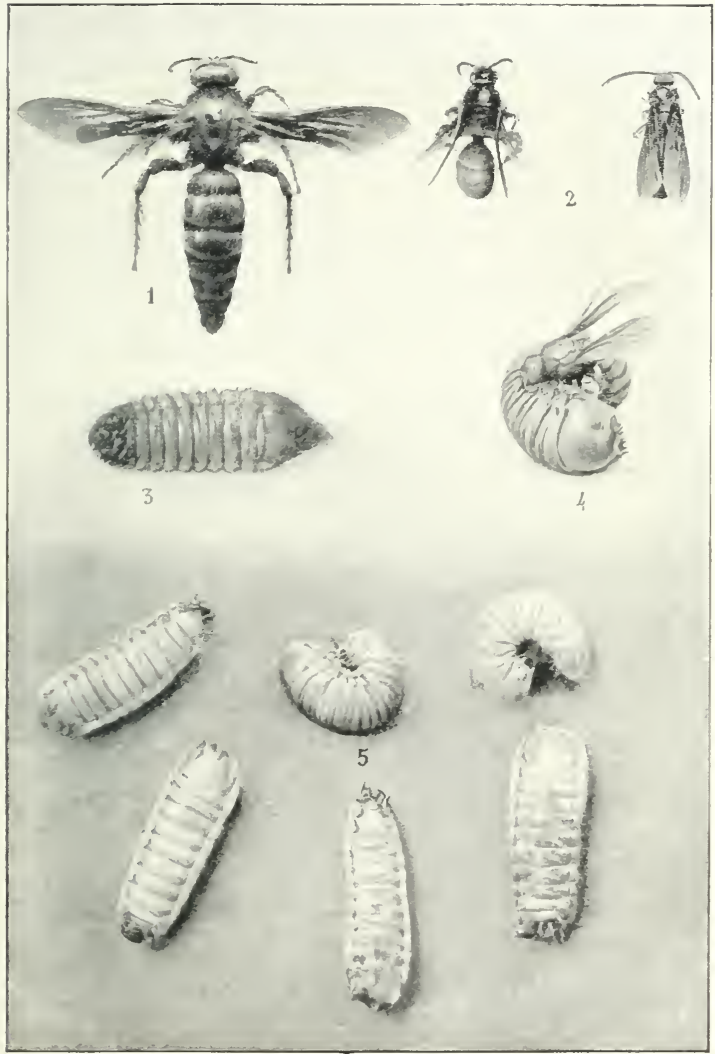

1. The ('ummon or Garden Scolia.

2. The Twe-jandel Scolia.

3. Grub of C'etonia Aurata progressing on its back.

4. The 'Two-banded Scolia paralyzing a Cetonia grub.

5. C'etonia grubs progressing on their backs, with their lers in the air ; two are in a resting position, rolled up. 

back. Suddenly, it buckles and, with a jerk of the head, flings the enemy to a distance. Undaunted by all her failures, the Hymenopteron stands up, brushes her wings and recommences the assault of the colossus, almost always by clambering on the grub by the rear extremity. At last, after any number of fruitless attempts, the Scolia succeeds in attaining the proper position. She lies across the grub; her mandibles hold a point of the thorax on the dorsal face tight-gripped; her body, curved into an arch, passes under the grub and reaches the neighbourhood of the neck with the tip of the belly. Placed in grave danger, the Cetonia twists, buckles, unbuckles, turns and writhes. The Scolia does not interfere. Holding her victim in a close embrace, she turns with it, allows herself to be dragged above, below, aside, at the mercy of the contortions. So fierce is her determination that I am now able to remove the glass bell and watch the details of the drama in the open.

Soon, notwithstanding the tumult, the tip of the Scolia's belly feels that the suitable point is found. Then and not till then is the dart unsheathed. It is driven home. The thing is done. The grub, but now active and swollen, suddenly becomes inert and limp. It is paralyzed. Henceforth, all movement ceases, save in the antennæ and mouth-pieces, which will continue for a long time to declare a remnant of life.

The place of the wound has never varied in the series of struggles under the glass bell : it occupies the middle of the dividing line between the prothorax and the mesothorax, on the ventral surface. Let us observe that the Cerceris, who operates upon Weevils, which insects have a concentrated nervous chain like that of the Cetonia grub, inserts her sting at the same point. The similarity of the 


\section{THE LIFE AND LOVE OF THE INSECT}

nervous organization occasions a similarity of method. Let us observe also that the sting of the Scolia remains for some time in the wound and rummages with a pronounced persistency. To judge by the movements of the tip of the abdomen, one would say that the weapon is exploring and selecting. Free to turn about as it pleases within narrow limits, the sting's point is probably searching for the little bundle of nerves which it must prick, or at least sprinkle with poison, in order to obtain a withering paralysis.

I will not end my report of the duel without relating a few more facts, of minor importance. The Two-banded Scolia is an ardent persecutor of the Cetonia. At one sitting, the same mother stabs three grubs, one after the other, before my eyes. She refuses the fourth, perhaps through fatigue, or because her poison-phial is exhausted. Her refusal is but temporary. The next day, she begins anew and paralyzes two worms ; the following day again, but with a zeal that diminishes from day to day.

The other predatory insects that go on long huntingexpeditions embrace the prey which they have rendered lifeless, drag it, convey it, each in its own fashion, and, laden with their burden, long try to escape from the bell and to reach the burrow. Disheartened by vain attempts, they abandon it at last. The Scolia does not move her prey, which lies indefinitely on its back at the spot of sacrifice. After drawing her dagger from the wound, she leaves her victim alone and starts fluttering against the walls of the bell, without troubling about it further. Things must happen in the same way in the manure-heap, under normal conditions. The paralyzed morsel is not carried elsewhither, to a special cellar: where the struggle occurred, there it receives, on its spread 
belly, the egg whence the consumer of the succulent dainty will presently emerge. This saves the expense of a house. It goes without saying that the Scolia does not lay under glass : the mother is too prudent to expose her egg to the dangers of the open air.

A second detail strikes me : the fierce persistency of the Scolia. I have seen the fight prolonged for a good quarter of an hour, with frequent alternations of successes and reverses, before the Hymenopteron achieved the requisite position and reached with the tip of her belly the point at which the sting must enter. During her assaults, which are resumed as soon as repelled, the aggressor repeatedly applies the extremity of her abdomen against the grub, but without unsheathing; for I should perceive this by the start of the animal injured by the prick. The Scolia, therefore, does not sting the Cetonia anywhere until the desired point offers beneath the weapon. The fact that no wounds are made elsewhere is not in any way due to the structure of the grub, which is soft and penetrable at all points, except the skull. The spot sought by the sting is no less well-protected than the others by the dermal wrapper.

In the struggle, the Scolia, curved archwise, is sometimes caught in the vice of the Cetonia, which forcibly contracts and buckles itself. Heedless of the rough embrace, the Hymenopteron does not let go with either her teeth or her ventral tip. Then follows a confused scuffle between the two locked insects, of which first one and next the other is on the top. When the grub succeeds in ridding itself of its enemy, it unrolls itself afresh, stretches itself at full length and proceeds to paddle along on its back with all possible speed. Its defensive artifices amount to no more than this. At an earlier 
period, when I had not yet seen for myself and was obliged to take probability for my guide, I was willing to grant it the trick of the hedgehog, who rolls himself into a ball and defies the dog. I thought that, doubled up, with a force which my fingers had some difficulty in overcoming, it would in like manner defy the Scolia, who was powerless to unroll it and disdainful of any point but that of her choice. I wished the grub to possess and I believed that it did possess this very simple and efficacious means of defence. But I had too great confidence in its ingenuity. Instead of copying the hedgehog and remaining contracted, it flees with its belly in the air ; foolishly, it adopts the very posture which allows the Scolia to make the assault and to reach the point at which the fatal blow is struck.

Let us pass on to others. I have just captured an Interrupted Scolia (Colpa Interrupta, Latr.), exploring the sands, no doubt in quest of game. It is important to make use of her as soon as may be, before her ardour has been cooled by the tedium of captivity. I know her prey, the grub of Anoxia Australis; I know, from my old habits of digging, the spots beloved by the worm: the sand-dunes heaped by the wind at the foot of the rosemary-shrubs on the slopes of the neighbouring hills. It will be hard work finding it, for nothing is rarer than a common thing, when it is needed in a hurry. I call in the aid of my father, an old man of ninety, but still straight as a wand. Shouldering a shovel and a threepronged luchet, we set out under a sun in which you could cook an egg. Exerting our feeble powers in turns, we cut a trench in the sand where I hope to find the Anoxia. My hopes are not disappointed. In the sweat of my brow -never was truer word spoken-after shifting and sifting 
through my fingers at least two cubic yards of sandy soil, I am the fortunate possessor of two grubs. Had I not wanted them, I should hare dug them up by the handful! However, my lean and costly harvest is sufficient for the moment. To-morrow, I shall send stronger arms to continue the digging.

And now let us repay ourselves for our trouble by witnessing the drama under glass. Heavy and clumsy in her ways, the Scolia moves slowly round the arena. At the sight of the game, her attention wakes up. The fight is heralded by the same preparations as those displayed by the Two-banded Scolia: the Hymenopteron polishes her wings and taps the table with the tips of her antennæ. And now, up, lads, and at 'em! The attack begins. Unfit to move over a flat surface, because of its short, weak legs; lacking, moreover, the Cetonia's eccentric means of locomotion on its back, the big-bellied worm does not dream of running away: it rolls itself up. The Scolia, with her powerful nippers, grabs its skin, now at once place, now at another. Buckled into an arch whose two ends almost meet, she strives to thrust the tip of her belly into the narrow opening of the volute formed by the grub. The fight is conducted quite calmly, without hard blows and with varying fortunes. It represents the obstinate attempt of a live split ring trying to slip one of its ends into another live split ring, which displays an equal obstinacy in remaining closed. The Scolia holds the game in subjection with her legs and mandibles; she makes her attempt first on one side and then on the other, without succeeding in unrolling the torus, which becomes the more contracted the more it feels itself in danger. The actual circumstances make the operation difficult: the prey slips and rolls over the table, when the insect 
goes for it too briskly; points of support are wanting and the sting cannot reach the desired spot; for over an hour, one vain attempt follows upon the other, divided by spells of rest, during which the two adversaries look like two narrow rings wound one inside the other.

What ought the sturdy Cetonia grub to do in order to defy the Two-banded Scolia, who is nothing like so strong as her victim? Imitate the Anoxia, of course, and remain rolled up like a hedgehog until the enemy retreats. It tries to flee, unrolls itself and thus causes its own undoing. The other does not budge from its defensive posture and resists successfully. Is this due to acquired prudence? No, but to the impossibility of acting otherwise on the polished surface of a table. Heavy, obese, weak-legged, bent into a hook after the manner of the common white maggot, the Anoxia grub is unable to shift its position on a smooth surface; it flounders painfully, lying on its side. What it wants is the shifting soil wherein, using its mandibles as a spade, it digs and buries itself.

Let us try if sand will shorten the battle, of which the end does not yet seem in sight after an hour's waiting. I lightly sprinkle the arena. The attack is resumed more fiercely than ever. The grub, feeling the sand, its natural dwelling-place, now also tries to slip away, the reckless one ! What did I tell you? Its torus does not represent acquired prudence, but the necessity of the moment. The harsh experience of past misfortunes has not yet taught it the precious advantage which it would derive from its volute kept closed as long as danger lasts. Besides, not all are equally cautious on the firm support of my table. The biggest even seem ignorant of what they understood so well in their youth: the art of self-defence by rolling one's self in a ball. 
I take up my story again with a fine-sized quarry, less liable to slip under the Scolia's pushes. The grub, when assailed, does not curl up, does not contract into a ring, like its predecessor, which was younger and but half its size. It tosses about clumsily, lying on its side, half-opened. Its only attempt at defence is to wriggle; it opens, closes and reopens its big mandibular hooks. The Scolia grabs it at random, winds her rough, hairy legs around it and, for nearly fifteen minutes, strives her hardest atop of the rich dainty.

At last, after a series of not very riotous affrays, the favourable position is gained, the propitious moment arrives and the sting is planted in the grub's thorax, at a central spot, under the neck and level with the fore-legs. The cffect is instantaneous: total inertia, save in the appendages of the head, the antennæ and mouth-pieces. I find the same results, the same prick at a precise, invariable spot, among my different operators, captured from time to time with a successful stroke of the net.

Let us say, in conclusion, that the attack delivered by the Interrupted Scolia is much less fiery than that of her two-banded sister. This rough, sand-digging Hymenopteron has a clumsy gait and stiff, almost automatic movements. She does not easily repeat her daggerthrust. Most of those with whom I experimented refused a second victim on the day after their exploits and on the following day. Half-asleep, they grew excited only when stimulated through my teasing them with a straw. Nor does the Two-banded Scolia, that more agile, more enthusiastic huntress, invariably unsheath when invited so to do. All those Nimrods are liable to moments of inaction which the presence of a new prey will not succeed in disturbing. 


\section{THE LIFE AND LOVE OF THE INSECT}

The Scoliæ have taught me no more than I have said, for lack of subjects belonging to other species. No matter : the results obtained constitute, to my mind, no small triumph. After seeing the Scoliæ at work, I said to myself, guided merely by the anatomical structure of the victims, that the grubs of Cetonia, of Anoxia, of Oryctes must be paralyzed with a single prick of the sting; I even specified the point at which the dagger had to strike, a central point in the immediate neighbourhood of the fore-legs. Of the three kinds of sacrificers, two allowed me to be present at their surgical operation, which the third, I am certain, will not contradict. In both cases, a single blow of the lancet; in both cases, an inoculation with the poison at the place settled in advance. No calculator in an observatory could show greater accuracy in foretelling the position of his planet. An idea may be considered proved when it attains this mathematical anticipation of the future, this positive knowledge of the unknown. When will the extollers of chance achieve a like success? Order calls for order ; and chance has no rule. 
THE RINGED CALICURGUS 



\section{CHAPTER XII}

\section{THE RINGED CALICURGUS}

THe non-euirassed victims, pervious to the sting over almost the whole of their body, such as Common Caterpillars and "Land-surveying" Caterpillars, Cetonia and Anoxia grubs, whose sole means of defence, apart from their mandibles, consists in rollings and eontortions, summoned another prey to my glass bell : the Spider, almost as ill-proteeted, but armed with formidable poison-fangs. How, more particularly, does the Ringed Calieurgus, or Pompilus, set to work to deal with the blaek-bellied Tarantula, the terrible Lycosa Narbonnensis, who slays mole and sparrow with a bite and imperils the life of man? How does the bold Pompilus overeome an adversary stronger than herself, better-endowed in virulence of poison and capable of making a meal of her assailant? Among the hunting insects, none faces such disproportionate contests, in which appearances seem to point to the aggressor as the prey and to the prey as the aggressor.

The problem deserved patient study. True, judging by the Spider's structure, I antieipated a single stab in the centre of the thorax; but this did not explain the vietory of the Hymenopteron, emerging safe and sound from her encounter with a quarry of that description. The matter must be looked into. The ehief difficulty is the 


\section{THE LIFE AND LOVE OF THE INSECT}

scarcity of the Calicurgus. To obtain the Tarantula is easy enough : the part of the neighbouring upland as yet untilled by the vine-planters supplies me with as many as I need. To capture the Calicurgus is a different story. I count upon her so little that I consider a special scarch quite useless. To look for one would, perhaps, be the very way not to find one. Let us leave it to chance to decide whether I shall have one or not.

I have one. I caught her unexpectedly on the flowers. The next day, I lay in a stock of half-a-dozen Tarantulas. Perhaps I shall be able to use them one after the other, in repeated duels. On my return from my expedition in search of Lycosæ, chance smiles upon me again and gratifies my desires to the full. A second Calicurgus presents herself before my net : she is dragging her heavy, paralyzed Arachnid by the leg, in the dust of the highroad. I set great store by my find : there is an urgency about laying the egg ; and I believe that the motber will accept an exchange without much hesitation.

So behold my two captives, each under a glass bell with her Tarantula. I am all eyes. What a drama I may expect, in a moment! I wait, anxiously. . . . But ... but. .. what is this? Which of the two is the attacker? Which of the two the attacked? The characters seem inverted. The Calicurgus, unfit for climbing up the smooth walls of the bell, strides along the outer circumference of the arena. With proud, swift gait and quivering wings and antennæ, she comes and goes. She soon sets eyes upon the Lycosa, marches up to her without the least sign of fear, turns around her and seems about to seize one of her legs. But, at that moment, the Tarantula rises almost perpendicularly, using her four hind-legs to stand upon and her four front-legs erect, 
outspread, ready to thrust and parry. The poison-fangs yawn wide: a drop of venom hangs from their point. The mere sight of them makes my flesh creep. In this terrible attitude, presenting her powerful chest and the black velvet of her belly to her enemy, the Arachnid overawes the Pompilus, who abruptly turns to the rightabout and retreats. The Lycosa then closes her case of poisoned daggers and returns to her natural position, standing on her eight legs; but, at the least aggressive movement on the part of the Hymenopteron, she resumes her threatening posture.

Nay, she does better: suddenly, she leaps and flings herself upon the Calicurgus, grapples with her nimbly and gnaws her with her fangs. The other, without replying with her sting, releases herself and emerges unscathed from the fierce encounter. Time after time, I witness the attack; and nothing serious ever happens to the Hymenopteron, who quickly extricates herself and seems to have felt nothing. Her manœuvres are resumed as boldly and swiftly as at the start.

Does this mean that the creature escaping from the terrible fangs is invulnerable? Obviously not. A real bite would be fatal to her. Big, tough Acridians succumb : why should not she, with her delicate organization, succumb as well? The Arachnid's daggers, therefore, make vain feints; their points do not enter the antagonist's flesh. If the blows were real, I should see bleeding wounds, I should see the fangs closed for a moment upon the point seized, whereas all my watchfulness fails to perceive anything of the sort. Are the fangs powerless, then, to pierce the Calicurgus' envelope? Not that either. I have seen them go through the corselet of the Acridians, which possesses much greater resisting 


\section{THE LIFE AND LOVE OF THE INSECT}

power and which cracks like a broken breastplate. Once more, whence comes this strange immunity of the Calicurgus between the legs and under the daggers of the Tarantula? I do not know. At a time when she is in mortal danger in front of her enemy, the Lycosa threatens her with her fangs and cannot bring herself to bite, prevented by a reluctance which I do not undertake to explain.

Seeing that I am obtaining nothing but alarms and scrimmages devoid of seriousness, I decide to alter the conditions of the prize-ring and to make it resemble more closely the natural state. My work-table is but a poor substitute for the soil; besides, the Arachnid has not her stronghold, her burrow, which maybe plays a part of some importance in both attack and defence. A stump of reed is stuck perpendicularly in a large pan filled with earth. This shall represent the Lycosa's pit. In the middle, I plant a few heads of echinops, made appetizing with honey, as a refectory for the Pompilus; a pair of Crickets, renewed as soon as consumed, shall keep up the strength of the Tarantula. This comfortable abode, exposed to the sun, receives the two captives under a woven-wire corer, well-ventilated and suitable for a long stay.

My artifices lead to no result; the session ends without business done. A day passes, two days, three days; and still nothing. The Calicurgus is unremitting in her attentions to the honeyed thistle-heads; the Tarantula calmly nibbles away at her Cricket. If the other comes within reach of her, she quickly draws herself up and, with a gesture, orders her to be off. The artificial burrow, the reed-stump, fulfils its purpose nicely. Lycosa and Calicurgus take refuge in it by turns, but without quarrelling. 
And that is all. The drama of which the prologue promised so well now seems to me indefinitely postponed.

A last resource remains; and I base great hopes upon it. This is to move my Calicurgi to the very spot of their investigations and to instal them at the door of the Arachnid's house, above the natural burrow. I take the field with an apparatus which I am dragging for the first time into the open, consisting of a glass cover, another of woven wire, together with the different instruments necessary to handle and shift my irascible and dangerous subjects. My search for burrows among the pebbles and the tufts of thyme and lavender soon meets with success.

Here is a splendid one. The insertion of a straw informs me that it is inhabited by a Tarantula of a size suited to my plans. I sweep and flatten down the neighbourhood of the orifice to receive the wire bell, under which I place a Pompilus. This is a fitting moment to light one's pipe and wait, stretched on the pebbles. . . . A further disappointment! Half an hour passes and the Hymenopteron confines herself to turning round the wire, as she did in my study. Not a sign of cupidity on her part in the presence of that burrow at the bottom of which I see the Tarantula's diamond eyes gleaming.

The wire-work enclosure is replaced by one of glass, the walls of which cannot be scaled, thus obliging the insect to remain on the ground and at last to take notice of the pit, which it seems to ignore. This time, we are more successful. After a few strolls round the circuit, the Calicurgus casts eyes upon the cavity that yawns beneath her feet. She goes down it. This boldness staggers me. I should never have dared expect as much as that. To fling yourself suddenly upon the Tarantula when she is outside her domain is all very well; but to 


\section{THE LIFE AND LOVE OF THE INSECT}

plunge into the lair when the terrible animal is waiting for you there with her double poisoned dagger! What will come of this temerity? A flutter of wings rises from the depths. Run to earth in her private apartments, the Lycosa is doubtless struggling with the intruder. That noise of wings is the song of victory of the Calicurgus, unless, indeed, it be her death-song. The murderer may well be the murdered. Which of the two will emerge from below alive?

It is the Lycosa, who hurriedly scampers out and takes up her stand at the entrance to the burrow in her position of defence, with her fangs open and her four front-legs outstretched. Is the other stabbed? Not at all, for she comes out forthwith, not without receiving a cuff, as she passes, from the Arachnid, who at once returns to her den. Dislodged from the basement a second and a third time, the Tarantula always comes up again without a wound, always waits for the invader on the doorsill, administers punishment and pops in again. In vain I alternate my two Pompili and change the burrow: I do not succeed in seeing anything more. Certain conditions, which my stratagems fail to realize, are lacking to the fulfilment of the drama.

Discouraged by the repetition of my fruitless experiments, I throw up the game, having gained, however, a fact of some value: the Calicurgus descends, without the least fear, into the Tarantula's den and turns her out. I imagine that things happen in the same way outside my bells. Evicted from her home, the Arachnid is more timorous and lends herself better to the attack. Besides, in the constraint of a narrow burrow, the operator would not be able to wield her lancet with the precision which her plans demand. The bold incursion shows us once again, more clearly than the hand-to-hand encounters on my 


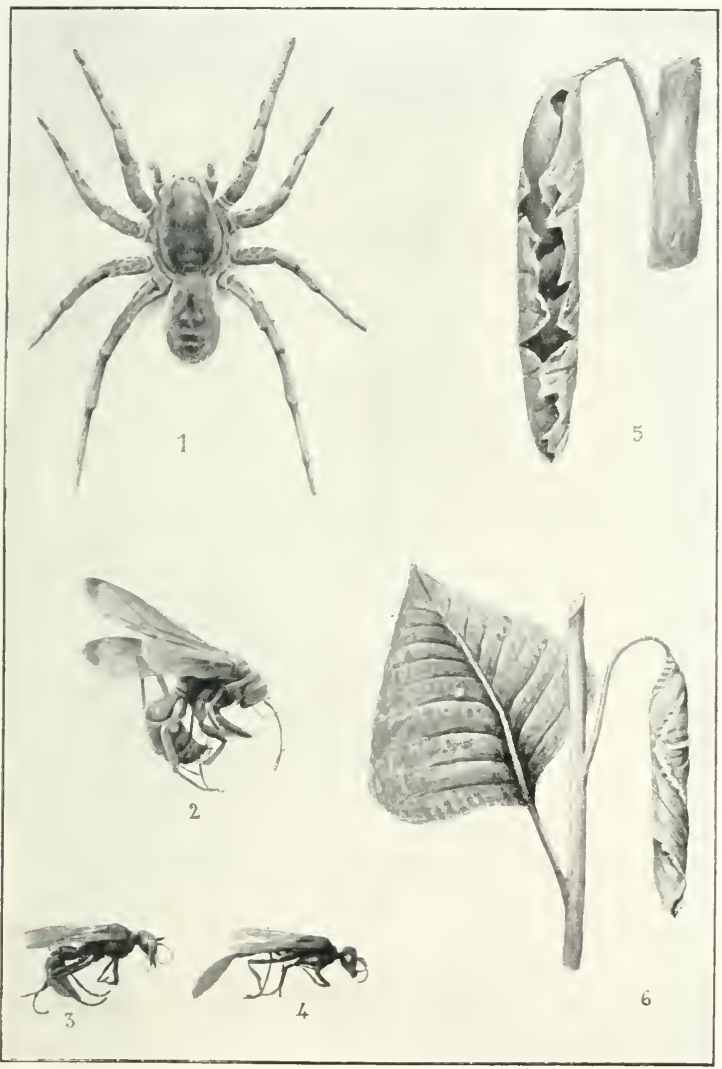

1. Lycosa Varbonensis.

3. Ammoplizla llirsuta.

5. Scroll of lihynchites Vitis.
2. The Ringed Calieurcus.

4. Ammoplizla Sululosa.

6. Scroll of Rithynctites I'opu'i. 

table, the Lycosa's reluctance to drive her fangs into her adversary. When the two are face to face at the bottom of the lair, that surely would be the time of times to have a word with the enemy. The Tarantula is at home; every nook and corner of the bastion is familiar to her. The intruder is constrained in her movements; she does not know her way about. Quick, a bite, my poor Lycosa, and your persecutor's done for! You refrain, I know not why; and your reluctance is the rash one's salvation. The silly sheep docs not reply to the butcher's knife with a butt from his horned forehead. Can you be the sheep of the Calicurgus?

My two subjects are once more installed in my study, under their wire domes, with the bed of sand, the reedstump burrow and renewed honey. They here find their first Lycosæ, feeding on crickets. The cohabitation extends over three weeks, without other incidents than scrimmages and threatenings, which become rarer from day to day. No serious hostility on either side. At last, the Calicurgi die : their day is past. A pitiful ending to a spirited start.

Shall I abandon the problem? Oh, no! It is not the first that has been unable to deter me from an eagerly-cherished plan. Fortune favours the persevering. She proves this by offering me, in September, a fortnight after the death of my Tarantula-hunters, a different Calicurgus, captured for the first time. It is Calicurgus Curra, clad in the same showy style as her predecessors and almost of the same size.

I know nothing about the new-comer : I wonder what she would like. A spider, that is certain : but which? A huntress of her build calls for big game : perhaps the Silky Epeira, perhaps the Banded Epeira, the two fattest Arachnids in the country, next to the Tarantula. The 


\section{THE LIFE AND LOVE OF THE INSECT}

first hangs her great vertical web, in which the Crickets are caught, from one brake of brushwood to the next. I shall find her in the copses on the adjacent hills. The other stretches hers across the ditches and little watercourses frequented by the Dragon-flies. I shall find her near the Aygues, on the bank of the irrigation-canals fed by that torrent. Two excursions procure me the two Epeiræ. Next day, I offer them together to my captive, who shall choose according to her tastes.

The choice is soon made : Epeira Fasciata obtains the preference. But she does not yield without protest. At the Hymenopteron's approach, she draws herself up and assumes a defensive attitude copied from that of the Lycosa. The Calicurgus does not mind the threats: under her harlequin attire, she is quick to strike and swift of foot. A few brisk cuffs are exchanged and the Epeira lies overturned on her back. The Calicurgus is on top of her, belly to belly, head to head; with her legs, she overpowers the Arachnid's legs ; with her mandibles, she grips the cephalothorax. She curves her abdomen vigorously, bringing it underneath; she draws her sting and ...

One moment, reader, if you please. Where is the sting going to penetrate? According to what we have learnt from the other paralyzers, it will be in the chest, to destroy the movement of the legs. You think so? I believed it too. Well, without wasting time in apologizing for our very excusable common error, let us confess that the animal is cleverer than we are. It knows how to make certain of success by means of a preparatory trick which you and I had not thought of. Oh, what a school is that of the animals! Is it not a fact that, before striking the adversary, it is wise to take steps not to be hit yourself? Calicurgus Scurra does not disregard this 
counsel of prudence. The Epeira carries under her throat two sharp daggers, with a drop of poison at the tip ; the Calicurgus is lost if the Arachnid bite her. Nevertheless, her anæsthetizing operation requires perfect security of the lancet. What is to be done in this peril, which would perplex the most confident surgeon? We must first disarm the patient and operate upon him later.

Behold, the Calicurgus' sting, aimed from back to front, enters the Epeira's mouth, with minute precautions and emphatic persistency. Upon the instant, the poisonfangs close limply and the formidable prey is rendered harmless. The Hymenopteron's abdomen then extends its arch and drives in the needle behind the fourth pair of legs, on the median line, almost at the juncture of the belly. The skin is thinner and more easily penetrable at this spot than elsewhere. The rest of the chest is covered with a firm breast-plate, which the sting would perhaps not succeed in perforating. The ncrve-centres, the seat of the movement of the legs, are situated a little higher than the wounded spot; but the aiming of the weapon from back to front enables it to reach them. This last blow produces paralysis of the eight legs together.

To enlarge upon the proceeding would spoil the eloquence of this manœuvre. First, for the protection of the operator, a stab in the mouth, that fearsomely armed point, to be dreaded above all others ; next, for the protection of the grub, a second stab in the nerve-centres of the thorax, to destroy all movement. I suspected indeed that the sacrificers of powerful Arachnids were endowed with special talents; but I was far from expecting their daring logic, which disarms before it paralyzes. This must also be the scheme followed by the Tarantulahuntress, who refused to disclose her secret under my bells. I know her method now, divulged as it is by a 
colleague. She turns the horrible Lycosa on her back, deadens her daggers by stinging her in the mouth and then, with a single prick of the needle, contrives the paralysis of the legs at her ease.

I examine the Epeira immediately after the operation and the Tarantula when the Calicurgus drags her by one leg to her burrow, at the foot of a wall. For a little while longer, a minute at most, the Epeira convulsively moves her legs. As long as these dying quivers last, the Pompilus does not let go of her prey. She seems to be watching the progress of the paralysis. With the tip of her mandibles, she repeatedly explores the mouth of the Arachnid, as though to make sure that the poison-fangs are really harmless. Next, all becomes quiet; and the Calicurgus makes ready to drag her prey elsewhither. It is then that I take possession of it.

What strikes me first of all is the absolute inertness of the fangs, which I tickle with a straw without succeeding in rousing them from their torpor. The feelers, on the contrary, the feelers, their immediate neighbours, move backwards and forwards the moment I touch them. I put the Epeira away safely in a flask and subject her to a fresh examination a week later. Irritability has returned in part. Under the stimulus of the straw, I see the limbs move a little, especially the lower joints, legs and tharsi. The feelers are even more irritable and mobile. These various movements, however, are devoid of vigour or coordination; and the Spider cannot use them to turn herself and still less to shift her position. As for the poison-fangs, I stimulate them in vain; I do not succeed in inducing them to open, or even to move. They are, therefore, profoundly paralyzed and in a special manner. I thought as much, at the beginning, from the peculiar persistency displayed by the dart in stinging the mouth. 
At the end of September, almost a month after the operation, the Epeira is in the same condition, neither dead nor alive : the feelers still quiver at the touch of the straw ; and nothing else stirs. Finally, after six or seven weeks of lethargy, real death supervenes, together with its companion, corruption.

The Tarantula of the Ringed Calicurgus, whom I steal from her owner while she is dragging her along, offers the same peculiarities for my inspection. The poison-fangs absolutely refuse to be irritated by the tickling of the straw, a fresh proof added to that of analogy to show that the Lycosa, like the Epeira, has been stung in the mouth. The feelers, on the other hand, are and for weeks remain exceedingly irritable and mobile. I insist upon this point, the interest of which will soon become apparent.

It was not possible for me to obtain a second attack from my Calicurgus Scurra: the tedium of captivity injured the exercise of her talents. Besides, the Epeira had occasionally something to say to this refusal: a certain stratagem of war twice employed before my eyes could easily rout the aggressor. Let me describe the thing, if only to raise a little in our esteem those silly Arachnids, who, provided with weapons of perfection, dare not use them against their feebler, but pluckier assailant.

The Epeira occupies the wall of the woven-wire enclosure, with her eight legs sprawling over the trelliswork; the Calicurgus moves about under the top of the dome. Panic-stricken at the sight of the enemy, the spider drops to the ground, with her belly in the air and her legs bunched up. The other goes to her, takes hold of her, examines her and places herself in a position to sting her in the mouth. But she does not unsheathe her dart. I see her leaning attentively over the poison-fangs, as though to enquire into the nature of the terrible 


\section{THE LIFE AND LOVE OF THE INSECT}

machinery; and then she moves away. The spider remains motionless, so much so that I believe her dead, paralyzed without my knowing it, at a moment when I was not looking. I take her out of the volery to examine her at my ease. But no sooner is she laid upon the table than she comes to life and promptly scurries away. The trickster was shamming for dead under the Calicurgus' dagger and so artfully that I was taken in by her. She hoodwinked one cleverer than myself, the Calicurgus, who inspected her very closely and did not consider a dead body worthy of her steel. Perhaps the simpleton alrearly noticed a "high" smell, like the bear in the fable.

This trick, if trick there be, appears to me to turn most often to the disadvantage of the Arachnid: Tarantula, Epeira or another, as the case may be. The Calicurgus, who has just thrown her on her back, after a brisk wrestling-match, knows well enough that the insect on the ground is not dead. The Spider, thinking to protect herself, shams the lifelessness of a corpse ; the assailant takes advantage of this to strike her most dangerous blow, the stab in the mouth. If the poison-tipped fangs were to open then, to snap, to bite in their despair, the Calicurgus would never dare expose the tip of her stomach to their mortal sting. The pretence of death is just what causes the success of the huntress in her risky operation. We are told, $O$ ingenuous Epeiræ, that the struggle for life counselled you to adopt that inert attitude in your own defence. Well, the struggle for life has shown herself a very bad counsellor. You would do better to believe in common sense and learn, by degrees, at your cost, that a quick parry-and-thrust, especially when your resources permit of it, is still the best way of striking awe into the enemy. 
THE OLD WEEVILS 



\section{CHAPTER XIII}

\section{THE OLD WEEVILS}

Is winter, when the insect enjoys an enforced rest, the study of numismatics procures me some delightful moments. I love to interrogate its metal disks, the records of the petty things which men call history. In this soil of Provence, where the Greek planted the olivetree and the Roman planted the law, the peasant finds coins, scattered more or less everywhere, when he turns his sod. He brings them to me and consults me as to their pecuniary value, never as to their meaning.

What matters to him the inscription on his treasuretrove! Men suffered of yore, they suffer to-day, they will suffer in the future: to him, all history is summed up in that! The rest is sheer futility, a pastime of the idle.

I do not possess this lofty philosophy of indifference to things of the past. I scratch the piece of money with my finger-nail, I carefully strip it of its earthy rind, I examine it with the magnifying-glass, I try to decipher its legend. And my satisfaction is no small one when the little round bronze or silver disk has spoken. For then I have read a page of humanity, not in books, which are witnesses open to suspicion, but in records which are, in a manner, living and which were contemporary with the persons and the facts. 
This bit of silver, flattened by the blow of the punch, talks to me of the Vocontii : " VOOC ... VOCVNT," says the inscription. It comes from the little neighbouring town of Vaison, where Pliny the Naturalist sometimes went to spend a holiday. Here, perhaps, at the table of his host, the celebrated compiler, he learnt to appreciate the beccafico, famous among the epicures of Rome and still renowned to-day, under the name of grasset, among our Provençal gastronomers. It is a shame that my bit of silver says nothing of these events, more memorable than a battle.

It shows, on one side, a head and, on the other, a galloping horse, all barbarously inaccurate. A child trying its hand for the first time with the point of a pebble on the fresh mortar of the walls would produce no more shapeless design. Nay, of a surety, those gallant Allobroges were no artists.

How greatly superior to them were the foreigners from Phocæa! Here is a drachma of the Massalietes $:^{2}$ MASIA IIHTSN. On the obverse, a head of Diana of Ephesus, chub-faced, full-cheeked, thick-lipped. A receding forehead, surmounted by a diadem ; an abundant head of hair, streaming down the neck in a cascade of curls; heavy ear-drops, a necklace of pearls, a bow slung over the shoulder. Thus was the idol decked by the hands of the pious maidens of Syria. To tell the truth, it is not beautiful. It is sumptuous, if you will, and preferable, after all, to the ass's ears which the beauties

1 The Vocontii inhabited the Viennaise, between the Allobroges on the north, the Caturiges and the estates of King Cottius on the east the Cavares on the west. and the Memini and Vulgientes on the south. Vasio (Vocontia), now Vaison, was their capital. - Translator's Note.

2 From Massalia, the ancient name of Marseilles, of which Phocæa, in Asia Minor, was the mother city.-Transiator's Note. 
of our days wear perched upon their heads. What a singular freak is fashion, so fruitful in the means of uglification! Business knows nothing of beauty, says this divinity of the traders; it prefers the profitable, embellished with luxury. Thus speaks the drachma.

On the reverse, a lion clawing the earth and roaring wide-mouthed. Not of to-day alone is the savagery that symbolizes power under the form of some formidable brute, as though evil were the supreme expression of strength. The eagle, the lion and other bandits often figure on the reverse of coins. But the reality is not sufficient; the imagination invents monstrosities: the centaur, the dragon, the hippogriff, the unicorn, the double-headed eagle. Are the inventors of these emblems really superior to the redskin who celebrates the prowess of his scalping-knife with a bear's paw, an eagle's wing or a jaguar's tooth stuck into his scalp-lock? We may safely doubt it.

How preferable to these heraldic horrors is the reverse of our own silver coinage brought into circulation of late years! It shows us a sower who, with a nimble hand, at sunrise, fills the furrow with the good seed of thought. It is very simple and it is great; it makes us think.

The Marseilles drachma has for its sole merit its magnificent relief. The artist who made the dies was a master of the graver's tool ; but he lacked the breath of inspiration. The chub-faced Diana is a rakes' wench and no better.

Here is the NAMASAT of the Volscx, which became the colony of Nîmes. Side by side, profiles of Augustus and his minister Agrippa. The former, with his hard brow, his flat skull, his grasping, broken nose, inspires me with 


\section{THE LIFE AND LOVE OF THE INSECT}

but little confidence, notwithstanding what gentle Virgil wrote of him :

\section{Deus nobis haec otia fecit.}

It is success that makes gods. Had he not succeeded in his criminal projects, Augustus the divine would have remained Octavius the scoundrel.

His minister pleases me better. He was a great shifter of stones, who, with his building operations, his aqueducts, his roads, came to civilize the rustic Volscæ a little. Not far from my village, a splendid road crosses the plain in a straight line, starting from the banks of the Aygues, and climbs up yonder, tedious in its monotonous length, to cross the Sérignan hills, under the protection of a powerful oppidum, which, much later, became the old castle, the Castelas. It is a section of Agrippa's Road, which joined Marseilles and Vienne. The majestic ribbon, twenty centuries old, is still frequented. We no longer see the little brown foot-soldier of the Roman legions upon it ; in his stead, we see the peasant going to market at Orange, with his flock of sheep or his drove of unruly porkers. And I prefer the latter.

Let us turn over the green-crusted penny. "COL. NEM.," colony of Nîmes, the reverse tells us. The inscription is accompanied by a crocodile chained to a palmtree from which hang crowns. It is an emblem of Egypt, conquered by the veterans who founded the colony. The beast of the Nile gnashes its teeth at the foot of the familiar tree. It speaks to us of Antony, the rip; it tells us of Cleopatra, whose nose, had it been an inch shorter, would have changed the face of the world. Thanks to the memories which it awakens, the scalyrumped reptile becomes a superb historical lesson.

1 Nemansus, the Latin name of Nîmes.-Translator's Note. 
In this way, the great lessons of the numismatical science of metals could follow one another for many a day and be constantly varied without leaving my near neighbourhood. But there is another science of numismatics, far superior and less costly, which, with its medals, the fossils, tells us the history of life. I speak of the numismatics of stones.

My very window-ledge, the confidant of bygone ages, talks to me of a vanished world. It is, literally speaking, an ossuary, each particle of which retains the imprint of past lives. That block of stone has lived. Spines of sea-urchins, teeth and vertebræ of fish, broken pieces of shells, shivers of madrepores form a pulp of dead existences. Examined ashlar by ashlar, my house would resolve itself into a reliquary, a rag-fair of things that were alive in the days of old.

The rocky layer from which building-materials are derived in these parts covers, with its mighty shell, the greater portion of the neighbouring upland. Here the quarry-man has dug for none knows how many centuries, since the time when Agrippa hewed cyclopean flags to form the stages and façade of the Orange theatre. And here, daily, the pick-axe uncovers curious fossils. The most remarkable of these are teeth, wonderfully polished in the heart of their rough veinstone, bright with enamel as though still in a fresh state. Some of them are most formidable, triangular, finely jagged at the edges, almost as large as one's hand. What an insatiable abyss, a jaw armed with such a set of teeth in manifold rows, placed stepwise almost to the baek of the gullet; what mouthfuls, snapped up and lacerated by those serrate shears! You are seized with a shiver merely at the imaginary reconstruction of that awful implement of destruction! 


\section{THE LIFE AND LOVE OF THE INSECT}

The monster thus equipped as a prince of death belonged to the order of Squalidæ. Paleontology calls him Carcharodon Megalodon. The shark of to-day, the terror of the seas, gives an approximate idea of him, in so far as the dwarf can give an idea of the giant.

Other Squali abound in the same stone, all fierce gullets. It contains Oxyrhinæ (Oxyrhina Xiphodon, Agass.), with teeth shaped like pointed cleavers; Hemipristes (Hemipristis Serra, Agass.), whose jaws are furnished with curved and toothed Malay creeses; Lamiæ (Lamia Denticulata, Agass.), whose mouths bristle with flexuous, steeled daggers, flattened on one side, convex on the other ; Notidani (Notidanus Primigenius, Agass.), whose sunk teeth are crowned with radiate indentations.

This dental arsenal, the eloquent witness of the old butcheries, can hold its own with the Crocodile of Nîmes, the Diana of Marseilles, the Horse of Vaison. With its panoply of carnage, it tells me how extermination came at all times to lop off the surplus of life; it says :

"On the very spot where you stand meditating upon a shiver of stone, an arm of the sea once stretched, filled with truculent devourers and peaceable victims. A long gulf occupied the future site of the Rhône Valley. Its billows broke at no great distance from your dwelling."

Here, in fact, are the cliffs of the bank, in such a state of preservation that, on concentrating my thoughts, I seem to hear the thunder of the waves. Sea-urchins, Lithodomi, Petricolæ, Pholaidids have left their signatures upon the rock: hemispherical recesses large enough to contain one's fist, round cells, eabins with a narrow conduit-pipe through which the recluse received the incoming water, constantly renewed and laden with nourishment. Sometimes, the erstwhile occupant is there, 
mineralized, intact to the tiniest details of his striæ and scales, a frail ornament; more often, he has disappeared, dissolved, and his house has filled with a fine sea mud, hardened into a chalky kernel.

In this quiet inlet, some eddy has collected and drowned at the bottom of the mire, now turned into marl, enormous heaps of shells, of every shape and size. It is a molluscs' burying-ground, with hills for tumuli. I dig up oysters a eubit long and weighing five or six pounds apiece. One eould shovel up, in the immense pile, Scallops, Cones, Cytheridæ, Mactridæ, Murices, Turritellidæ, Mitridæ and others too numerous, too innumerable to mention. You stand stupefied before the vital ardour of the days of old, which was able to supply such a pile of relics in a mere nook of earth.

The neeropolis of shells tells us, besides, that time, that patient renewer of the order of things, has mown down not only the individual, a preearious being, but also the species. Nowadays, the neighbouring sea, the Mediterranean, has almost nothing identical with the population of the vanished gulf. To find a few features of similarity between the present and the past, we should have to seek them in the tropical seas. The elimate, therefore, has become colder; the sun is slowly becoming extinguished; the species are dying out. Thus speak the numismatics of the stones on my window-ledge.

Without leaving my field of observation, so modest, so limited and yet so rich, let us onee more consult the stone and, this time, on the subject of the inseet. The eountry round Apt abounds in a strange rock that breaks off in thin plates, similar to sheets of whitish cardboard. It burns with a sooty flame and a bituminous smell ; and it was deposited at the bottom of great lakes haunted by 


\section{THE LIFE AND LOVE OF THE INSECT}

crocodiles and giant tortoises. Those lakes no human eye has ever seen. Their basins have been replaced by the ridges of the hills; their muds, peacefully deposited in thin courses, have become mighty banks of rock.

Let us break off a slab and subdivide it into sheets with the point of a knife, a work as easy as separating the superposed layers of a piece of paste- or mill-board. In so doing, we are examining a volume taken from the library of the mountains, we are turning the pages of a magnificently illustrated book. It is a manuscript of nature, far superior to the Egyptian papyrus. On almost every page are diagrams; nay, better : realities converted into pistures.

On this page are fish, grouped at random. One might take them for a dish fried in oil. Back-bones, fins, vertebral links, bones of the head, crystal of the eye turned to a black globule, everything is there, in its natural arrangement. One thing alone is absent: the flesh. No matter : our dish of gudgeons looks so good that we feel an inclination to scratch off a bit with our finger and taste this supramillenary preserve. Let us indulge our fancy and put between our teeth a morsel of this mineral fry seasoned with petroleum.

There is no inscription to the picture. Reflection makes good the deficiency. It says to us :

"These fishes lived here, in large numbers, in peaceful waters. Suddenly, swells came and asphyxiated them in their mud-thickened waves. Buried forthwith in the mire and thus rescued from the agents of destruction, they have passed through time, will pass through it indefinitely, under the cover of their winding-sheet."

The same swells brought from the adjacent rain-swept shores a host of refuse, both vegetable and animal, so 
much so that the lacustrian deposit talks to us also of things on land. It is a general record of the life of the time.

Let us turn a page of our slab, or rather our album. Here are winged seeds, leaves drawn in brown prints. The stone herbal vies in botanical accuracy with a normal herbal. It repeats what the shells had already told us: the world is changing, the sun is losing its strength. The vegetation of modern Provence is not what it was in former days ; it no longer includes palmtrees, camphor-yielding laurels, tufted araucarias and many other trees and shrubs whose equivalents belong to the torrid regions.

Continue to turn the pages. We now come to the insects. The most frequent are the Diptera, of middling size, often very humble flies and gnats. The teeth of the great Squali astonished us by their soft polish amid the roughness of their chalky veinstone. What shall we say of these frail midges preserved intact in their marly shrine? The frail creature, which our fingers could not grasp without crushing it, lies undeformed beneath the weight of the mountains !

The six slender legs, which the least thing is enough to disjoint, here lie spread upon the stone, correct in shape and arrangement, in the attitude of the insect at rest. There is nothing lacking, not even the tiny double claws of the extremities. Here are the two wings, unfurled. The fine net-work of their nervures can be studied under the lens as clearly as in the Dipteron of the collections, stuck upon its pin. The antennary tufts have lost none of their subtle elegance; the belly gives us the number of the rings, edged with a row of atoms that were cilia. 
The carcase of a mastodont, defying time in its sandy bed, already astonishes us : a gnat of exquisite delicacy, preserved intact in the thickness of the rock, staggers our imagination.

Certainly, the Mosquito, carried by the rising swells, did not come from far away. Before his arrival, the hurlyburly of a thread of water must have reduced him to that annihilation to which he was so near. He lived on the shores of the lake. Killed by the joys of a morning-the old age of gnats-he fell from the top of his reed, was forthwith drowned and disappeared in the muddy catacombs.

Who are those others, those dumpy ones, with hard, convex elytra, the most numerous next to the Diptera? Their small heads, prolonged into a snout, tell us plainly. They are proboscidian Coleoptera, Rhynchophora, or, in less hard terms, Weevils. There are small ones, middling ones, large ones, similar in dimensions to their counterparts of to-day.

Their attitudes on the chalky slab are not as correct as those of the Mosquito. The legs are entangled anyhow ; the beak, the rostrum is at one time hidden under the chest, at another projects forward. Some show it in profile; others-more frequent these-stretch it to one side, as the result of a twist in the neck.

These dislocated, contorted insects did not receive the swift and peaceful burial of the Dipteron. Though sundry of them may have lived on the plants on the banks, the others, the majority, come from the surrounding neighbourhood, brought by the rains, which warped their joints in crossing such obstacles as branches and stones. A stout armour has kept the body unscathed, but the delicate articulations of the members have given way 
to some extent; and the miry winding-sheet received the drowned Beetles as the disorder of the passage left them.

These strangers, come perhaps from afar, supply us with precious information. They tell us that, whereas the banks of the lake had the Mosquito as the chief representative of the insect class, the woods had the Weevil.

Outside the snout-carrying family, the sheets of my Apt rock show me hardly anything more, especially in the order of the Coleoptera. Where are the other terrestrial groups, the Carabus, the Dung-beetle, the Capricorn, which the wash of the rains, indifferent as to its harvests, would have brought to the lake even as it did the Weevil? There is not the least vestige of those tribes, so prosperous to-day.

Where are the Hydrophilus, the Gyrinus, the Dytiscus, all inhabitants of the water? These lacustrians had a great chance of coming down to us mummified between two sheets of marl. If there were any in those days, they lived in the lake, whose muds would have preserved these horn-clad insects even more perfectly than the little fishes and especially than the Dipteron. Well, of those aquatic Coleoptera there is no trace either.

Where were they, where were those missing from the geological reliquary? Where were they of the thickets, of the green-sward, of the worm-eaten trunks: Capricorns, borers of wood ; Sacred Beetles, workers in dung ; Carabi, disembowellers of game? One and all were in the limbo of the time to come. The present of that period did not possess them: the future awaited them. The Weevil, therefore, if I may credit the modest records which I ain free to consult, is the oldest of the Coleoptera. 


\section{THE LIFE AND LOVE OF THE INSECT}

Life, at the start, fashioned oddities which would be screaming discords in the present harmony of things. When it invented the Saurian, it revelled at first in monsters fifteen and twenty yards long. It placed horns on their noses and eyes, paved their backs with fantastic scales, hollowed their necks into spiny wallets, wherein their heads withdrew as into a hood. It even tried, though not with great success, to give them wings. After these horrors, the procreating ardour calmed down and produced the charming green Lizard of our hedges.

When it invented the bird, it filled its beak with the pointed teeth of the reptile and appended a long, feathered tail unto its rump. These undetermined and revoltingly ugly creatures were the distant prelude to the Robin Redbreast and the Dove.

All these primitives are noted for a very small skull, an idiot's brain. The brute of antiquity is, first and foremost, an atrocious machine for snapping, with a stomach for digesting. The intellect does not count as yet. That will come later.

The Weevil, in his fashion, to a certain extent, repeats these aberrations. See the extravagant appendage to his little head. It is here a short, thick snout; there a sturdy beak, round or cut four-square ; elsewhere a crazy reed, thin as a hair, long as the body and longer. At the tip of this egregious instrument, in the terminal mouthpiece, are the fine shears of the mandibles; on the sides, the antennæ, with their first joints set in a groove.

What is the use of this beak, this snout, this caricature of a nose? Where did the insect find the model ? Nowhere. The Weevil is its inventor and retains the monopoly. Outside his family, no Coleopteron indulges in these briccal eccentricities. 
Observe, also, the smallness of the head, a bulb that hardly swells beyond the base of the snout. What can it have inside? A very poor nervous equipment, the sign of exceedingly limited instincts. Before seeing them at work, we make small account of these microcephali, in respect of intelligence; we class them among the obtuse, among creatures bereft of working capacity. These surmises will not be very largely upset.

Though the Curculio be but little glorified by his talents, this is no reason for scorning him. As we learn from the lacustrian schists, he was in the van of the insects with the armoured wing-cases; he was long stages ahead of the workers in incubation within the limits of possibility. He speaks to us of primitive forms, sometimes so quaint; he is, in his own little world, what the bird with the toothed jaws and the Saurian with the horned eyebrows are in a higher world.

In ever-thriving legions, he has been handed down to us without changing his characteristics. He is to-day as he was in the old times of the continents: the prints in the chalky slates proclaim the fact aloud. Under any such print, I would venture to write the name of the genus, sometimes even of the species.

Permanence of instinct must go with permanence of form. By consulting the modern Curculionid, therefore, we shall obtain a very approximate chapter upon the biology of his predecessors, at the time when Provence had great lakes filled with crocodiles and palm-trees on their banks wherewith to shade them. The history of the present will teach us the history of the past. 


\section{CHAPTER XIV}

\section{LEAF-ROLLERS}

THE attainments of the Curculionid mother are, generally speaking, limited to inserting her eggs at places where the grubs will find suitable nourishment and occasionally varying the diet with a botanical judgment of marvellous certainty. She displays little or no industry. The niceties of the feeding-bottle or the baby-linen do not concern her. To this rough conception of the duties of maternity, I know but one exception, the attribute of certain Weevils, who, in order to endow their young with an alimentary preserve, possess the art of rolling a leaf, which serves as board and lodging in one.

Among these manufacturers of regetable sausages, the most skilful is the Poplar Weevil (Rhynchites Populi, Lin.), who is modest in proportions, but resplendent in attire. Her back is clad in gleaming gold and copper; her back is indigo blue. Would you see her at work, you need but visit the lower twigs of the common black poplar, at the edge of the meadows, about the end of May.

Whereas, up at the top, the fond spring breezes shake the majestic green distaff and set the leaves quivering on their flattened stalks, down below, in a zone of calmer air, the tender shoots of the year remain quiescent. Here, especially, far from the wind-tossed heights opposed to 
labour, the Rhynchites works. And, as the workshop is just at a man's height, nothing is more easy than to observe the roller's actions.

Easy, yes, but distressing, under a blazing sun, if one would follow the insect in all the detail of its methods and the progress of its work. Moreover, this involves a great deal of walking, which takes up time ; and, again, it is not favourable to precise observations, which require an indefinite amount of leisure and assiduous visits at all hours of the day. It would, therefore, be greatly preferable to study the animal comfortably at home; but it is above all things necessary that she should lend herself to this plan.

The Rhynchites fulfils the condition excellently well. She is a peaceable enthusiast and works on my table with the same zest as in her poplar-tree. A few tender shoots, planted in fresh sand, under a woven-wire cover, and renewed as soon as they begin to fade, take the place of the tree in my study. The Wcevil, not in the least intimidated, derotes herself to her industry even under the lens of my magnifying-glass and supplies me with as many scrolls as I could wish for.

Let us watch her at work. She picks the leaf which she proposes to roll from the young shoots sprouting in sheaves at the base of the trunk, but picks it not among the lower leaves, which are already the correct green and of a firm texture, nor yet among the terminal leaves, which are in a fair way of growing. Above, they are too young, not wide enough; below, they are too old, too tough, too hard to manage.

The leaf selected belongs to the intermediate rows. As yet of a doubtful green, in which yellow predominates, soft and glossy with varnish, it has, or has very nearly, 


\section{THE LIFE AND LOVE OF THE INSECT}

the final dimensions. Its denticulations swell into delicate glandular pads, whence oozes a little of the viscous matter that tars the buds at the moment when their bracts become disjoined.

A word now on the equipment in respect of tools. The legs are supplied with double claws shaped like the meat-hooks of a steel-yard. The lower side of the tarsi carries a thick tuft of white bristles. Thus shod, the insect clambers very nimbly up the most slippery vertical walls; it can stand and run like a fly, with its back downwards, on the ceiling of a glass bell. This characteristic alone is enough to suggest the subtle sense of equilibrium which the Weevil's work will demand.

The curved and powerful beak or rostrum, without being exaggerated in size, spreads at the tip into a spatula ending in a pair of fine, shear-like mandibles. It makes an excellent bodkin, which plays the first or leading part in the whole work. The leaf, in fact, cannot be rolled in its actual condition. It is a live blade which, owing to the afflux of the sap and the tonicity of the tissues, would resume its flat formation in proportion as the insect endeavoured to curve it. The dwarf insect has not the strength to master a piece of these dimensions, to roll it up so long as it retains the elasticity of life. This is evident to our eyes ; it is evident also to the eyes of the Weevil.

How is she to obtain the degree of inert suppleness required in the circumstances? We ourselves would say :

"We must pluck the leaf, let it fall to the earth, and manipulate it on the ground when it is rightly withered." 
The Curculionid is cleverer than we at this sort of business and does not share our opinion. What she says to herself is :

"On the ground, amid the obstruction of the grass, my labours would be impracticable. I want elbow-room ; I want the thing to hang in the air, where there are no obstacles of any kind. And there is a more serious consideration : my grub would refuse a rank, dried-up sausage ; it insists on food that retains a certain freshness. The scroll which I intend for its consumption must be not a dead leaf, but an impaired leaf, not altogether deprived of the juices with which the tree supplies it. I must wean my joint, but not kill it outright, so that the dying leaf may remain in its place for the few days during which the extreme youth of the worm lasts."

The mother, therefore, having made her selection, takes up her stand on the stalk of the leaf and there patiently drives in her rostrum, turning it with a persistency that denotes the great importance of this thrust of the bodkin. A little wound opens, a fairly deep wound, which soon becomes a point of mortification.

It is done: the sap-conduits are cut and allow only a scanty proportion to ooze through to the edge. At the injured point, the leaf gives way under the weight; it bends vertically, withers a little and soon acquires the requisite flexibility. The moment has come to work it.

That bodkin-thrust represents, although much less scientifically, the prick of the hunting Hymenopteron's sting. The latter wants for her offspring a prey now dead, now paralyzed; she knows, with the thoroughness of a consummate anatomist, at what points it behoves her to insert the sting to obtain either sudden 


\section{THE LIFE AND LOVE OF THE INSECT}

death or merely a cessation of movement. The Rhynchites requires for her young a leaf rendered flexible ad hoc, half-alive, paralyzed in a fashion, a leaf that can easily be shaped into a scroll; she is wonderfully familiar with the little leaf-stalk, the petiole, in which the vessels that dispense the foliaceous energy are collected in a tiny bundle; and she inserts her drill there, there only and never any elsewhere. Thus, at one blow, without much trouble, she effects the ruin of the aqueduct. Where can the beaked insect have learnt her astute trade as a drier-up of wells?

The leaf of the poplar is an irregular rhombus, a spearhead whose sides widen into pointed pinions. The manufacture of the scroll begins with one of those two lateral corners, the right or left indifferently. Notwithstanding the hanging posture of the leaf, which makes the upper or lower surface equally easy of access, the insect never fails to take its position on the upper side. It has its reasons, dictated by the laws of mechanics. The upper surface of the piece, which is smoother and more flexible, has to form the inside of the scroll; the lower surface, which has greater elasticity because of its powerful veins, must occupy the outside. The statics of the small-brained Weevil agree with those of the scientists.

See her at work. She stands on the rolling-line, with three of her legs on the part already rolled and the three opposite on the part still free. Solidly fixed, on both sides, with her claws and tufts, she obtains a purchase with the legs on the one side, while making her effort with the legs on the other. The two halves of the machine alternate like motors, so that, at one time, the formed cylinder rolls over the free blade and, at another, the free blade moves and is laid upon the scroll already made. 
There is nothing regular, however, about these alternations, which depend upon circumstances known to the animal alone. Perhaps they merely afford a means of resting for a little while without stopping a work that does not allow of interruption. In the same way, our two hands mutually relieve each other by taking it in turns to carry the burden.

It is impossible to form an exact image of the difficulty overcome, without watching, for hours on end, the obstinate straining of the legs, which tremble with exhaustion and threaten to spoil everything if one of them let go at the wrong moment, or without seeing with what prudence the roller never releases one claw until the five others are firmly fixed. On the one side are three points of support, on the other three points of traction; and the six are shifted, one by one, little by little, without for a moment allowing their connected mechanical system to flag. A single instant of forgetfulness or weariness would cause the rebellious piece to unroll its scroll and escape from the manipulator's grasp.

The work is accomplished, moreover, in an uncomfortable position. The leaf hangs very much on the slant or even vertically. Its surface is varnished, is smooth as glass. But the worker is shod accordingly. With her tufted soles, she scales the polished perpendicular; with her twelve meat-hooks, she tackles the slippery floor. Yet this fine set of tools does not rid the operation of all its difficulties. I find it no easy matter to follow the progress of the rolling with the magnifying-glass. The hands of a watch do not move more slowly. The insect stands for a long time, at the same point, with its claws firmly fixed; it is waiting for the leaf to be mastered and to cease resistance. Here, of course, there 


\section{0}

\section{THE LIFE AND LOVE OF THE INSECT}

is no gumming-process to eatch hold and keep the fresh surfaces glued together. The stability depends purely upon the flexion acquired. And so it is not unusual for the elasticity of the piece to overeome the efforts of the worker and partly to unroll the more or less forward work. Stubbornly, with the same impassive slowness, the insect begins all over again, replaces the insubordinate pieee. No, the Weevil is not one to allow herself to be upset by failure: she knows too well what patience and time will do.

The Rhynchites usually works backwards. When her line is finished, she is careful not to abandon the fold which she has just made and return to the startingpoint to begin another. The part last folded is not yet fastened sufficiently; if left to itself too soon, it might easily rebel and flatten out again. The insect, therefore, persists at this extreme point, which is more exposed than the rest; and then, without letting go, makes her way baekwards to the other end, still with patient slowness. In this way, an added firmness is imparted to the fold; and the next fold is prepared. At the end of the line there is a fresh prolonged halt, followed by a fresh backward motion. Even so does the husbandman's plough-share alternate its work on the furrows.

Less frequently, when, no doubt, the leaf is found to be so limp as to entail no risk, the insect abandons the fold which it has just made, without going over it again in the opposite direction, and quickly scrambles to the starting-point to contrive a new one.

There we are at last. Coming and going from top to bottom and from bottom to top, the insect, by dint of stubborn dexterity, has rolled its leaf. It is now on the 
extreme edge of the border, at the lateral corner opposite to that whereat the work commenced. This is the keystone upon which the stability of the rest depends. The Rhynchites redoubles her cares and patience. With the end of her rostrum, expanded spatulawise, she presses, at one point after the other, the edge to be fixed, even as the tailor presses the recalcitrant edges of a seam with his iron. For a long, a very long time, without moving, she pushes and pushes, awaiting the proper adhesion. Point by point, the whole of the corner welt is fastidiously sealed.

How is adhesion obtained? If only some thread or other were brought into play, one would readily look upon the rostrum as a sewing-machine planting its needle perpendicularly into the stuff. But the comparison is not allowable: there is no filament employed in the work. The explanation of the adherence lies elsewhere.

The leaf is young, we said ; the fine pads of its denticulations are glands whence ooze liquid beads of glue. These drops of viscous matter are the gum, the sealing-wax. With the pressure of its beak, the insect makes it gush more plentifully from the glands. It then has only to hold the signet in position and wait for the impress to acquire consistency. Taken all round, it is our method of sealing a letter. If it hold ever so little, the leaf, losing its elasticity gradually as it withers, will soon cease to fly back and will of itself retain the scroll-form imposed upon it.

The work is done. It is a cigar of the diameter of a thick straw and about an inch long. It hangs perpendicularly from the end of the bruised and bent stalk. It has taken the whole of a day to make. After a short spell of rest, the mother tackles a second leaf and, working 


\section{THE LIFE AND LOVE OF THE INSECT}

by night, obtains another scroll. Two in twenty-four hours are as much as the most diligent can achieve.

Now what is the roller's object? Would she go to the length of preparing preserves for her own use? Obviously not: no insect, where itself alone is concerned, devotes such care and patience to the preparation of food. It is only in view of the family that it hoards so industriously. The Rhynchites' cigar forms the future dowry.

Let us unroll it. Here, between the layers of the scroll, is an egg; often there are two, three, or even four. They are oval, pale-yellow and like fine drops of amber. Their adhesion to the leaf is rery slight; the least jerk loosens them. They are distributed without order, pushed more or less deeply in the thickness of the eigar and always isolated, singly. We find them in the centre of the scroll, almost at the corner where the rolling begins; we come upon them between the different layers and even near the edge which is sealed in glue with the signet of the rostrum.

Without interrupting her work on the scroll, without relaxing the tension of her claws, the mother has laid them between the lips of the fold in formation, as she felt them coming, one by one, duly matured, at the end of her oviduct. She procreates in the midst of her toil in the factory, between the wheels of the machine that would be thrown out of gear if she snatched a moment's rest. Manufacture and laying go hand-in-hand. Short-lived, with but two or three weeks before her and an expensive family to settle, the Rhynchites would fear to waste her time in churching.

This is not all : on the same leaf, not far from the scroll that is being laboriously rolled, we almost always find the male. What is he doing there, the idler? Is he watching 
the work as a mere inquisitive onlooker, who happened to be passing and stopped to see the machinery go round ? Is he interested in the business? Does he ever feel inclined to lend a helping hand, in case of need ?

One would say so. From time to time, I see him take his stand behind the manufacturer, in the groove of the fold, hang on to the cylinder and join for a little in the work. But this is done without zeal and awkwardly. Half a turn of the wheel, or hardly; and that's enough for him. After all, it is not his business. He moves away, to the other end of the leaf; he waits, he looks on.

Let us give him credit for this attempt: paternal assistance in the settling of the family is very rare among insects ; let us congratulate him on the help he gives, but not beyond measure : his was an interested aid. It is to him a means of declaring his flame and urging his merits.

And, in fact, after several refusals, notwithstanding the advances made by a brief collaboration at the scroll the impatient one is accepted. Things happen in the workyard. For ten minutes, the rolling is suspended; but the workwoman's legs, stubbornly contracted, are careful not to let go : were their effort to cease, the scroll would unroll at once. There must be no interruption of work for this brief diversion, the animal's only pleasure.

The stopping of the machine, which is always held tight so as to keep the recalcitrant roll in subjection, does not last long. The male withdraws to a slight distance, without quitting the leaf, and the task is resumed. Sooner or later, before the seals are put upon the work, a new visit is paid by the dawdler, who, under pretence of assisting, plants his claws for a moment into the rolling piece, plucks up courage and renews his exploits with the 


\section{THE LIFE AND LOVE OF THE INSECT}

same vigour as though nothing had yet happened. And this is repeated three or four times during the making of a single cigar, so much so that one asks one's self whether the depositing of each germ does not demand the direct cooperation of the insatiable suitor.

According to entomologieal rules, once the fun is over, everything should relapse into calmness and each mother should to work at those cigars without further disturbance. In this case, the general law relents. I have never seen a scroll shaped without a male lurking in the neighbourhood; and, when I have had the patience to wait, I have always witnessed manifold pairings. These weddings repeated for each germ puzzle me. Where, relying on the books, I expected uniformity, I find uncertainty.

This is not an isolated case. I will mention a second and one that is even more striking. It is supplied by the Capricorn (Cerambyx Heros). I bring up a few couples in the volery, with sliced pears for food and oak billets wherein to lay the eggs. Pairing-time lasts during nearly the whole of July. For four weeks, the great horned one does nothing but mount his companion, who, gripped by her rider, wanders at will and, with the tip of her oviduct, selects the fissures in the bark best-suited to receive the eggs.

At long intervals, the Cerambyx alights and goes to refresh himself with a piece of pear. Then, suddenly, he stamps his feet as though he had gone mad; he returns with a frantic rush, clambers into the saddle and resumes his position, of which he makes free use at all hours of the night and day.

At the moment when an egg is being deposited, he keeps quiet: with his hairy tongue, he polishes the back of the egg-layer, which is a Capricorn's way of caressing ; 
but, the instant after, he renews his attcmpts, which are usually crowned with success. There is no end to it !

The pairing continues in this manner for a month : it does not cease until the ovaries are exhausted. Then, mutually worn out, having nothing more to do on the trunk of the oak, husband and wife separate, languish for a few days and die.

What conclusion are we to draw from this extraordinary persistency in the Cerambyx, the Rhynchites and many others? Simply this: our truths are but provisional; assailed by the truths of to-morrow, they become entangled with so many contradictory facts that the last word of knowledge is doubt.

In the spring, while the leaves of the poplar are being worked into scrolls, another Rhynchites, she also gorgeously attired, makes cigars of the leaves of the vine. She is a little stouter, of a metallic gold-green turning to blue. Were she but larger, the splendid Vine Weevil would occupy a very respectable place among the gems of entomology.

To attract our eyes, she has something better than the brilliancy of her appearance: she has her industry, which makes her hated by the vinc-grower, so jealous of his property. The peasant knows her ; he even speaks of her by a special name, an honour rarely bestowed in the world of the smaller animals.

The rural vocabulary is rich where plants, but very poor where insects are concerned. A couple of dozen words, inextricably confused owing to their general character, represent the whole of entomological nomenclature in the Provençal idiom, which becomes so expressive and so fertile the moment it has to do with any sort of vegetation, sometimes even with a poor blade of 


\section{THE LIFE AND LOVE OF THE INSECT}

grass which one would believe known to the botanist alone.

The man of the soil is interested first and foremost in the plant, the great foster-mother; the rest leaves him indifferent. Magnificent adornment, curious habits, marvels of instinet: all these say nothing to him. But to touch his vine, to eat grass that doesn't belong to one : what a heinous crime! Quick, give the malefactor a nickname, to serve as a penal collar!

This time, the Provençal peasant has gone out of his way to invent a spceial word: he calls the cigar-roller the B'́caru. Here the seientific expression and the rural expression agree fully. Rhynchites and Bécaru are exact equiralents : each refers to the insect's long beak.

The Vine Weevil adopts the same method in her work as her cousin of the poplar. The leaf is first pricked with the rostrum at a spot in the stalk, which provokes a stoppage of the sap and flexibility in the withered blade. The rolling begins at the corner of one of the lower lobes, with the smooth, green upper surface within and the cottony strongly-veined lower surface without.

But the great width of the leaf and its deep indentations hardly ever allow of regular work from one end to the other. Abrupt folds occur instead and repeatedly alter the direction of the rolling, leaving now the green and now the cottony surface on the outside, without any apprceiable order or arrangement, as though by chance. The poplar-leaf, with its simple form and its moderate size, gives a neat scroll ; the vine-leaf, with its eumbersome girth and its complicated outline, produces a shapeless eigar, an untidy parcel. 
THE HALIC'TI 



\section{CHAPTER XV}

\section{THE HALICTI}

Do you know the Halicti? Perhaps not. There is no great harm done: it is quite possible to enjoy the few pleasures of life without knowing the Halieti. Nevertheless, when questioned with persistence, those humble creatures with no history can tell us some very singular things; and their acquaintance is not to be disdained if we desire to enlarge our ideas a little upon the bewildering rabble of this world. Since we have nothing better to do, let us look into these Halieti. They are worth the trouble.

How shall we recognize them? They are manufacturers of honey, generally slimmer and slenderer than the Bee of our hives. They eonstitute a numerous group that varies greatly in size and colouring. Some there are that exeeed the dimensions of the Common Wasp; others might be compared with the Domestie Fly, or are even smaller. In the midst of this variety, which forms the despair of the novice, one eharacteristic remains invariable. Every Halictus earries the plainly-legible certificate of her guild.

Look at the last ring, at the tip of the belly, on the dorsal surface. If your eapture be an Halictus, there will be here a smooth and shiny line, a narrow groove along which the sting slides up and down when the insect is 
on the defensive. This slide for the unsheathed weapon denotes some member of the Halictus tribe, without distinction of size or colour. No elsewhere, in the stingbearing order, is this original sort of groove in use. It is the distinctive mark, the blazon of the family.

The works begin in April, discreetly and betrayed only by tiny mounds of fresh earth. There is no animation in the work-yards. The labourers show themselves very seldom, so busy are they at the bottom of their pits. At moments, here and there, the summit of a mole-hill moves and tumbles down the slopes of the cone : it is a worker coming up with her armful of rubbish and shooting it outside, without showing herself in the open. Nothing more for the moment.

May arrives, gay with flowers and sunshine. The navvies of April have turned themselves into harvesters. At every moment, I see them settling, all befloured with yellow, atop of the mole-hills turned into craters. The largest is Halictus Zebrus (Walck), whom I often see building her nest in the walks of my garden. Let us watch her closely. When provisioning-time begins, a parasite arrives, coming I know not whence. She will make us witness an unbridled act of brigandage.

In May, I visit my most populous colony daily, at ten o'clock in the morning, when the victualling-operations are in full swing. Seated on a low chair in the sun, with my back bent and my arms upon my knees, I watch, without moving, until dinner-time. What attracts me is a parasite, a trumpery Gnat, the daring tyrant of the Halictus.

Has the jade a name? I like to think so, without, however, caring to waste my time in enquiries that can have little interest for the reader. Facts clearly stated 
are preferable to the dry minutiæ of nomenelature. Let me content myself with giving a brief deseription of the culprit. She is a Dipteron five millimetres long. ${ }^{1}$ Eyes, dark red; face, white. Corselet, ashy grey, with five rows of fine black dots, which are the roots of stiff bristles pointing backwards. Greyish belly, pale below. Blaek legs.

She abounds in the colony under observation. Crouching in the sun, near a burrow, she waits. As soon as the Halictus arrives from the harvest, her legs yellow with pollen, she darts forth and pursues her, keeping behind her in all the turns of her wavering flight. At last, the Hymenopteron suddenly dives indoors. No less suddenly, the other settles on the mole-hill, quite close to the entrance. Mlotionless, with her head turned towards the front-door, she waits for the Bee to finish her business. The latter reappears at last and. for a few seeonds, stands on the threshold of her dwelling, with her head and thorax outside the hole. The Gnat, on her side, does not stir.

Often, they are face to face, separated by a space no wider than a finger's breadth. Neither of them shows the least excitement. The Halietus-judging, at least, by her tranquillity-takes no notice of the parasite lying in wait for her; the parasite, on the other hand, displays no fear of being punished for her audacity. She remains imperturbable, she, the dwarf, in the presence of the colossus who could crush her with a blow of one of her legs.

In vain I peer to discover some sign of apprehension on either side : nothing in the Halictus points to a knowledge of the danger run by her family; nor does anything in the Dipteron betray the dread of a severe correction.

1 '2 inch. - Translator's Note. 


\section{THE LIFE AND LOVE OF THE INSECT}

Plunderer and plundered stare at each other for a moment; and that is all.

If she liked, the genial giantess could rip up with her claw the little bandit that ruins her home; she could cruneh her with her mandibles, pink her with her stiletto. She does nothing of the sort, but leaves the brigand in peace, to sit quite close, motionless, with her red eyes fixed on the threshold of the house. Why this fatuous clemency?

The Bee departs. Forthwith, the Gnat walks in, with no more ceremony than if she were entering her own place. She now chooses among the victualled cells at her ease, for they are all open; she leisurely settles her eggs. No one will disturb her until the Bee's return. To dust one's legs with pollen, to distend one's crop with syrup is a work that takes long a-doing; and the intruder, therefore, has time to spare wherein to commit her felony. Noreover, her chronometer is well-regulated and gives the exact measure of the length of absence. When the Halictus comes back from the fields, the Gnat has decamped. In some favourable spot, not far from the burrow, she awaits the opportunity for a fresh misdeed.

What would happen if a parasite were surprised in her work by the Bee? Nothing serious. I have seen them, greatly daring, follow the Halictus right into the cave and remain there for some time while the mixture of pollen and honey is being prepared. Unable to make use of the paste so long as the harvester is kneading it, they go back to the open air and wait on the threshold for the Bee to come out. They return to the sunlight, unflustered, with calm steps : a clear proof that they have suffered no unpleasantness in the depths where the Halictus works. 
A tap on the Gnat's neck if she become too enterprising in the neighbourhood of the cake : that is all that the lady of the house seems to allow herself, to drive away the intruder. There is no serious affray between the robber and the robbed. This is apparent from the bold and undamaged aspect of the dwarf who returns from visiting the giantess engaged down in the burrow.

The Bee, when she comes home, whether laden with provisions or not, hesitates for a while ; in a series of rapid zigzags, she moves backwards and forwards, to and fro, at a short distance from the ground. This intricate flight at first suggests the idea that the Hymenopteron is trying to lead her persecutress astray by means of an inextricable net-work of marches and counter-marches. That would certainly be a prudent move on her part ; but so much wisdom appears to be denied her.

Her perturbation does not concern the enemy, but rather the difficulty of finding her dwelling, amid the confusion of the mole-hills encroaching one upon the other and the disorder of the lanes of the hamlet, which, owing to landslips of fresh rubbish, alter in appearance from one day to the next. Her hesitation is manifest, for she often blunders and alights at the entrance to a burrow that is not hers. The mistake is at once perceived from the petty details of the doorway.

The investigation is resumed with the same flight in swing-like curves, intermingled with sudden excursions to a distance. At last, the burrow is recognized. The Halictus dives into it with a rush ; but, however prompt her disappearance underground, the Gnat is there, perched on the threshold, with her eyes turned to the entrance, waiting for the Bee to come out, so that she may visit the honey-jars in her turn. 
When the house-owner ascends, the other draws back a little, just enough to leave a free passage and no more. Why should she put herself out? The meeting is so peaceful that, short of further information, one would not suspect the presence face to face of a destroyer and destroyed. Far from being intimidated by the sudden arrival of the Halictus, the Gnat pays hardly any attention; and, in the same way, the Halictus takes no notice of her persecutress, unless the bandit pursue her and worry her on the wing. Then, with a sudden bend, the Hymenopteron makes off.

The parasite of the Halictus is in a difficult position. The homing Bee has her booty of honey in her crop and her harvest of flour on the brushes of her legs: the first is inaccessible to the thief; the second is in the form of powder and devoid of stable support. And even then it is quite insufficient. To collect the wherewithal to knead the round loaf, the journeys have to be repeated. When the necessary amount is obtained, the Halictus will pound it with the tip of her mandibles and shape it with her feet into a globule. The Dipteron's egg, were it present among the materials, would certainly be in danger during this manipulation.

The alien egg, therefore, must be laid on the made bread; and, as the preparation takes place underground, the parasite is under the forced necessity of going down to the Halictus. With inconceivable daring, she does go down, even when the Bee is there. Whether through cowardice or foolish indulgence, the dispossessed insect lets the other have its way.

The object of the Gnat, with her tenacious lying-in-wait and her reckless burglaries, is not to feed herself at the harvester's expense : she could find the wherewithal to live 
on in the flowers, with much less trouble than her thieving trade involves. The most, I think, that she can allow herself to do in the Halictus' cellars is demurely to taste the victuals, in order to ascertain their quality. Her great, her sole business is to settle her family. The stolen goods are not for herself, but for her sons.

Let us dig up the pollen-loaves. We shall find them most often crumbled with no regard to economy, simply abandoned to waste. We shall see two or three maggots, with pointed mouths, moving in the yellow flour scattered over the floor of the cell. These are the Dipteron's progeny. With them we sometimes find the lawful owner, the worm of the Halictus, but stunted and emaciated with fasting. His gluttonous companions, without otherwise molesting him, deprive him of the best of everything. The wretched starveling dwindles, shrivels and disappears with little delay. His corpse, a mere atom, blended with the remaining provisions, supplies the maggots with one mouthful the more.

And what does the mother Halictus do in this disaster? She is free to visit her grubs at any moment; she has but to put her head into the passage of the house : she cannot fail to be apprised of their distress. The squandered loaf, the disorder of swarming vermin are events easily recognized. Why does she not take the intruders by the skin of the belly? To crush them with a bite of her mandibles, to fling them out of doors were the business of a second. And the foolish creature never thinks of it, leaves the famishers in peace!

She does worse. When the time of the nymphosis comes, the Halictus mother goes to the cells rifled by the parasite and closes them with an earthen plug as carefully as she does the rest. This final barricade, an excellent 


\section{THE LIFE AND LOVE OF THE INSECT}

precaution when the box is occupied by an Halictus in course of metamorphosis, becomes a screaming absurdity when the Dipteron has passed that way. Instinct does not hesitate in the face of this incongruity: it seals up emptiness. I say, emptiness, because the crafty maggot hastens to decamp the instant that the victuals are consumed, as though it foresaw an insuperable obstacle for the coming Fly : it quits the cell before the Hymenopteron closes it.

To rascally guile the parasite adds prudence. All, until there is none of them left, abandon the clay homes which would be their undoing, once the entrance was plugged up. The earthy retreat, so grateful to the tender skin, thanks to its polished coating, so free from humidity, thanks to its waterproof glaze, ought, one would think, to make an excellent waiting-place. The maggots will have none of it. Lest they should find themselves walled in when they become frail Gnats, they go away and disperse in the neighbourhood of the ascending pit.

My digging operations, in fact, always reveal the pupæ outside the cells, never inside. I find them enshrined, one by one, in the body of the clayey earth, in a narrow niche which the emigrant worm has contrived to make for itself. Next spring, when the hour comes for leaving, the adult insect has but to creep through the rubbish, which is easy work.

Another and no less imperative reason compels this change of abode on the parasite's part. In July, a second generation of the Halictus is procreated. The Dipteron, reduced, on her side, to a single brood, remains in the pupa state and awaits the spring of the following year before cffecting her transformation. The honey-gatherer resumes her work in the natal hamlet; she avails herself 
of the pits and cells construeted in the spring, saving no little time thereby. The whole elaborate structure has remained in good condition. It needs but a few repairs to make the old house habitable.

Now what would happen if the Bee, so intent upon cleanliness, were to find a pupa in the cell which she is sweeping? She would treat the cumbersome object as she would a piece of old plaster. It would be no more to her than any other refuse, a bit of gravel, which. seized with the mandibles, crushed perhaps, would be sent to join the rubbish-heap outside. Once removed from the soil and exposed to the inclemencies of the weather, the pupa would inevitably perish.

I admire this lucid foresight of the maggot, which foregoes the comfort of the moment for the seeurity of the future. Two dangers threaten it: to be immured in a casket whence the Fly ean never issue ; or else to die ont of doors, from the harsh effeets of the air, when the Bee sweeps out the restored cells. To avoid this two-fold peril, it absconds before the door is elosed, before the Halietus sets her house in order in July.

Let us now see what comes of the parasite's intrusion. In the course of June, when peace is established in the Halietus' home, I dig up my largest colony, comprising some fifty burrows, thoroughly. Not an atom of the underground distress shall eseape my eye. There are four of us engaged in sifting the excavated earth through our fingers. What one has examined another takes up and examines in his turn ; and then another and another yet. The returns are heart-rending. We do not succeed in finding one single nymph of the Halictus. The populous city has perished in its entirety; and its place has been taken by the Dipteron. The latter superabounds 


\section{THE LIFE AND LOVE OF THE INSECT}

in the form of pupe, which I collect in order to trace their evolution.

The year runs its course; and the little russet barrels, into whieh the original maggots have hardened and eontraeted, remain stationary. They are seeds endowed with latent life. The heats of July do not rouse them from their torpor. In that month, the period of the seeond generation of the Halictus, there is a sort of truce of God: the parasite rests and the Bee works in peace. If hostilities were to be resumed straight away, as murderous in summer as they were in spring, the progeny of the Halietus, over-endangered, might possibly disappear. The lull of the second brood puts things in order once more.

In April, when Halietus Zebrus, in seareh of a good place for her burrows, wanders with a wavering flight through the garden-walks, the parasite, on its side, hastens to hateh. Oh, the precise, the terrible agreement between those two ealendars, the calendar of the perseeutor and the persecuted! At the very moment when the Bee comes out, here is the Gnat : her work of extermination by famine is ready to begin all over again.

Were this an isolated case, one's thoughts would not dwell upon it: an Halictus more or less in the world makes little difference in the general balance. But, alas, brigandage in all its forms is the rule in the eternal eonflict of living things! From the lowest to the highest, every producer is imposed upon by the unproduetive. Man himself, whose exceptional rank ought to raise him above such pettiness, excels in this ferocious eagerness. He says to himself that business means getting hold of the money of other people, even as the Gnat says to herself that business means getting hold of the Halietus' honey. 
And, to play the brigand to better purpose, he invents war, the art of killing wholesale and of doing with glory that which, when done on a smaller scale, leads to the gallows.

Shall we never behold the realization of that sublime dream which is sung on Sundays in the smallest village church : Gloria in excelsis Deo et in terra pax hominibus bonce voluntatis! If war affected humanity alone, perhaps the future would have peace in store for us, seeing that generous minds are working for it with might and main; but the scourge also rages in the brute, which, in its obstinate way, will never listen to reason. Once the evil is laid down as a general condition, it perhaps becomes incurable. Life in the future, there is every cause to fear, will be what it is to-day, a perpetual massacre.

Whereupon, by a desperate effort of the imagination, one pictures to one's self a giant capable of juggling with the planets. He is irresistible strength; he is also law and justice. He knows of our battles, our butcheries, our farm-burnings, our town-burnings, our brutal triumphs; he knows our explosives, our shells, our torpedo-boats, our iron-clads and all our cunning engines of destruction ; he knows as well the appalling extent of the appetites among all creatures, down to the very lowest. Well, if that just, that mighty one held the earth under his thumb, would he hesitate whether he ought to crush it ?

He would not hesitate. He would let things take their course. He would say to himself :

"The old belief is right; the earth is a rotten nut, gnawed by the vermin of evil. It is a barbarous essay, a painful stage towards a kindlier destiny. Let it be : order and justice are waiting at the end." 


\section{CHAPTER XVI}

\section{THE HALICTI : THE PORTRESS}

THE home dug by the solitary Bee in early spring remains, when summer comes, the joint inheritance of the members of the family. There were ten cells, or thereabouts, undcrground. Now from these cells there have issued none but females. This is the rule among the three species of Halicti. They have two generations in each year. That of the spring consists of females only ; that of the summer comprises both males and females, in almost equal numbers.

The household, therefore, if not reduced by accidents, especially by the famine-producing Gnat, would consist of half-a-score of sisters, nothing but sisters, all equally industrions and all capable of procreating without a nuptial partner. On the other hand, the maternal dwelling is no hovel; far from it: the entrance-gallery, the prineipal room of the house, will serve very well, after a few odds and ends of refuse have been swept away. This will be so much gained in time, ever precious to the Bec. The cells at the bottom, the clay cabins, are also nearly intact. To make use of them, it will be enough to freshen up the stucco with the polisher of the tongue.

Well, which of the survivors, all equally entitled to the succession, will inherit the house? There are six of 210 
them, seven, or more, according to the chances of mortality. To whose share will the maternal dwelling fall?

There is no quarrel between the interested parties. The mansion is recognized as common property without dispute. The sister Bees come and go peacefully through the same door, attend to their business, pass and let the others pass. Down at the bottom of the pit, each has her little demesne, her group of cells dug at the cost of fresh toil, when the old ones, now insufficient in number, are occupied. In these recesses, the rights of individual property prevail : each mother works privately, jealous of her belongings and her isolation. Every elsewhere, traffic is free to all.

The exits and entrances in the working fortress provide a spectacle of the highest interest. A harvester arrives from the fields, the brushes of her legs dusted with pollen. If the door be open, the Bec at once dives underground. To tarry on the threshold would mean waste of time; and the business is urgent. Sometimes, several appear upon the scene almost at the same moment. The passage is too narrow for two, especially when they have to avoid any inopportune contact that would make the floury burden fall to the floor. The nearest to the opening enters quickly. The others, drawn up on the threshold in the order of their arrival, respectful of one another's rights, await their turn. As soon as the first disappears, the second follows after her and is herself swiftly followed by the third and then the others, one by one.

Sometimes, again, there is a meeting between a Bee about to come out and a Bee about to go in. Then the latter draws back a little and makes way for the former. The politeness is reciprocal. I see some who, when on 


\section{THE LIFE AND LOVE OF THE INSECT}

the point of emerging from the pit, go down again and leave the passage free for the one who has just arrived. Thanks to this mutual spirit of accommodation, the traffic of the household proceeds without impediment.

Let us keep our eyes open. There is something better than the well-preserved order of the entrances. When an Halictus appears, returning from her round of the flowers, we see a sort of trap-door, whieh closed the house, suddenly fall and give a free passage. As soon as the new arrival has entered, the trap rises back into its place, almost level with the ground, and closes the door anew. The same thing happens when the Bees go out. At a request from within, the trap descends, the door opens and the Bee flies away. The outlet is closed forthwith.

What can this shutter be which, descending or ascending in the cylinder of the pit, after the fashion of a piston, opens and eloses the house at each departure and at each arrival? It is an Halictus, who has become the portress of the establishment. With her large head, she makes an impassable barrier at the top of the entrance-hail. If any one belonging to the house wants to go in or out, she "pulls the cord," that is to say, she withdraws to a spot where the gallery widens and leaves room for two. The other passes. She then at once returns to the orifice and blocks it with the top of her head. Motionless, ever on the look-out, she does not leave her post save to drive away importunate visitors.

Let us profit by her brief appearances outside. We recognize in her an Halictus similar to the others, who are now busy harvesting; but the top of her head is bald and her dress is dingy and threadbare. The handsome 
striped belts, alternately brown and ruddy-brown, have almost vanished from her half-stripped back. Her old, tattered clothes, well-worn with work, explain the matter clearly.

The Bee who mounts guard and performs the office of a portress at the entrance to the burrow is older than the others. She is the foundress of the establishment, the mother of the actual workers, the grandmother of the present grubs. In the spring-time of her life, three months ago, she wore herself out in solitary works. Now that her ovaries are dried up, she takes a well-earned rest. No, rest is hardly the word. She still works, she assists the household to the best of her power. Incapable of being a mother for the second time, she becomes a portress, opens the door to the members of her family and makes strangers keep their distance.

The suspicious kid, looking through the chink, said to the wolf :

"Show me a white foot, or I shan't open the door."

No less suspicious, the grandmother says to each comer :

"Show me the yellow foot of an Halictus, or you won't be let in."

None is admitted to the dwelling unless she be recognized as a member of the family.

See for yourself. Near the burrow passes an Ant, an unscrupulous adventuress, who would not be sorry to know the meaning of the honeyed fragrance that rises from the bottom of the cellar.

"Be off, or mind yourself !" says the portress, with a movement of her neck.

As a rule, the threat suffices. The Ant decamps. Should she insist, the watcher leaves her sentry-box, 


\section{THE LIFE AND LOVE OF THE INSECT}

flings herself upon the saucy jade, buffets her and drives her away. The moment the punishment has been administered, she returns on guard and resumes her sentry-go.

Next comes the turn of a Leaf-cutter (Megachile Albocincta, Pérez), who, unskilled in the art of burrowing, utilizes, after the manner of her kind, the old galleries dug by others. Those of Halictus Zebrus suit her very well, when the terrible Gnat of spring has left them vacant for lack of heirs. Seeking for a home wherein to stack her robinia-leaf honey-pots, she often makes a flying inspection of my colonies of Halicti. A burrow seems to take her fancy; but, before she sets foot on earth, her buzzing is noticed by the watchwoman, who suddenly darts out and makes a few gestures on the threshold of her door. That is all. The Leaf-cutter has understood. She removes herself.

Sometimes, the Megachile has time to alight and insert her head into the mouth of the pit. In a moment, the portress is there, comes a little higher and bars the way. Follows a not very serious contest. The stranger quickly recognizes the rights of the first occupant and, without insisting, goes to seek an abode elsewhere.

A consummate marauder (Cælioxys Caudata, Spinola), a parasite of the Megachile, receives a sound drubbing under my eyes. She thought, the scatter-brain, that she was entering the Leaf-cutter's establishment! She soon finds out her error; she meets the portress Halictus, who administers a severe correction. She makes off at full speed. And so with the others who, by mistake or ambition, seek to enter the burrow.

The same intolerance exists among grandmothers. About the middle of July, when the animation of the 
colony is at its height, two categories of Halicti are easily distinguishable: the young mothers and the old. The former, much more numerous, brisk of movement and smartly arrayed, come and go unceasingly from the burrows to the fields and from the fields to the burrows. The latter, faded and dispirited, wander idly from hole to hole. They look as though they had lost their way and were incapable of finding their homes. Who are these vagabonds? I see afflicted ones bereft of a family through the act of the odious spring Gnat. Many burrows have gone under altogether. At the awakening of summer, the mother found herself alone. She left her empty house and set off in search of a dwelling where there were cradles to defend, a guard to mount. But those fortunate nests already have their overseer, the foundress, who, jealous of her rights, gives her unemployed neighbour a cold reception. One sentry is enough ; two would simply block the narrow guard-room.

I am privileged at times to witness a fight between two grandmothers. When the tramp in quest of employment appears outside the door, the lawful occupant does not move from her post, does not withdraw into the passage, as she would before an Halictus returning from the fields. Far from making way, she threatens with her feet and mandibles. The other hits back, tries to enter notwithstanding. Cuffs are exchanged. The fray ends by the defeat of the stranger, who goes off to pick a quarrel elsewhere.

These little seenes afford us a glimpse of certain details of the highest interest in the manners of Halictus Zebrus. The mother who builds her nest in the spring no longer leaves her home, once her works are finished. Shut up at the bottom of the burrow, busied with the minute cares 


\section{THE LIFE AND LOVE OF THE INSECT}

of housekeeping, or else drowsing, she waits for her daughters to come out. When, in the summer heats, the life of the colony recommences, having naught to do outside as a harvester, she stands sentry at the entrance to the hall, so as to let none in save the workers of the home, her own daughters. She wards off the ill-intentioned. None can enter without the door-keeper's consent.

There is nothing to tell us that the watcher at moments deserts her post. I never see her leave her house to go and refresh herself at the flowers. Her age and her sedentary occupation, which implies no great fatigue, relieve her perhaps of the need of nourishment. Perhaps, also, the young ones returning from pillage disgorge a drop of the contents of their crops for her benefit, from time to time. Fed or not, the old one no longer goes out.

But what she does need is the joys of an active family. Nany are deprived of these. The Dipteron's burglary has destroyed the household. The sorely-tried Bees then abandon the deserted burrow. It is these who, ragged and careworn, wander through the hamlet. They move in short flights ; more often, they remain motionless. It is they who, embittered in their natures, offer violence to their acquaintances and seek to dislodge them. They grow rarer and more languid from day to day; then they disappear for good. What has become of them? The little grey lizard had his eye on them: they are easy mouthfuls.

Those settled in their own demesne, those who guard the honey-factory wherein their daughters, the heiresses of the maternal establishment, work display a wonderful vigilance. The more I visit them, the more I admire 
them. In the cool hours of the early morning, when the harvesters, not finding the pollen-flour sufficiently ripened by the sun, remain indoors, I see the portresses at their posts, at the top of the gallery. Here, motionless, their heads flush with the earth, they bar the door to all invaders. If I look at them too closely, they retreat a little way and, in the shadow, await the indiscreet observer's departure.

I return when the harvest is in full swing, between eight o'clock and twelve. There is now, as the Halicti go in or out, a succession of prompt descents to open the door and ascents to close it. The portress is in the busy exercise of her functions.

In the afternoon, the heat is too great, tho workers do not go to the fields. Retiring to the bottom of the house, they varnish the new cells, they bake the round loaf that is to receive the egg. The grandmother is still upstairs, stopping the door with her bald head. For her, there is no nap during the stifling hours: the general safety will not allow of it.

I come back again at night-fall, or even later. By the light of a lantern, I rebehold the overseer, as zealous and assiduous as in the day-time. The others are resting, but not she, for fear, apparently, of nocturnal dangers known to herself alone. Does she nevertheless end by descending to the quiet of the floor below? It seems probablo, so essential must rest be, after the fatigue of such a watch!

It is evident that, guarded in this manner, the burrow is exempt from calamities similar to those which, too often, dispeople it in May. Let the Gnat come now, if she dare, to steal the Halictus' loaves! Her audacity, her stubborn lurking ways will not conceal her from the watchful one, who will put her to flight with a threatening gesture or, if 


\section{THE LIFE AND LOVE OF THE INSECT}

she persist, crush her with her nippers. She will not come; and we know the reason: until spring returns, she is underground in the pupa state.

But, in her absence, there is no lack, among the Muscid rabble, of further sweaters of other insects' labour. There are parasites for every sort of business, for every sort of theft. And yet my daily visits do not catch one of these in the neighbourhood of the July burrows. How well the rascals know their trade! How well-aware are they of the guard who keeps watch at the Halictus' door! There is no foul deed possible nowadays ; and the result is that no Muscid puts in an appearance and the tribulations of last spring are not repeated.

The grandmother who, dispensed by age from maternal worries, mounts guard at the entrance of the home and watches over the safety of the family tells us of sudden births in the genesis of the instincts; she shows us an immediate capacity which nothing, either in her own past conduct or in the actions of her daughters, could have led us to suspect. Timorous in her prime, in the month of May, when she lived alone in the burrow of her making, she has become gifted, in her decline, with a superb contempt of danger and dares, in her impotence, what she never dared do in her strength.

Formerly, when her tyrant, the Gnat, entered her home in her presence, or, more often, stood at the entrance, face to face with hersclf, the silly Bee did not stir, did not even threaten the red-eyed bandit, the dwarf whose doom she could so easily have sealed. Was it terror on her part? No, for she attended to her duties with her usual punctiliousness; no, for the strong do not allow themselves to be thus petrified by the weak. It was ignorance of the danger, it was sheer foolishness. 
And behold, to-day, the ignoramus of three months ago, without serving any apprenticeship, knows the peril, knows it well. Every stranger that appears is kept at a distance, without distinction of size or race. If the threatening gesture be not enough, the keeper sallies forth and flings herself upon the persistent one. Poltroonery has developed into courage.

How has this change been brought about? I should like to picture the Halictus gaining wisdom from the misfortunes of spring and capable thenceforth of looking out for danger; I would gladly credit her with having learnt in the stern school of experience the advantages of a guard. I must give up the idea. If, by dint of gradual littlo acts of progress, the Bee has gradually achieved the glorious invention of a portress, how comes it that the fear of thieves is intermittent? It is true that, alone, in May, she cannot stand permanently at her door: the business of the house takes precedence of everything. But she ought, at least, as soon as her offspring are persecuted. to know the parasite and give chase when, at every moment, she finds her almost under her feet and oven in her house. Yet she pays no attention to her.

The harsh trials of the ancestors, therefore, have be. queathed naught to her of a nature to alter her placid character; and her own tribulations have nothing to say to the sudden awakening of her vigilance in July. Like ourselves, the animal has its joys and its troubles. It uses the former eagerly; it bothers but little about the latter, which is, when all is said, the best way of realizing an animal enjoyment of life. To mitigate these troubles and protect the progeny there is the inspiration of the instinct, which is able to give a portress to the Halictus without the counsels of experience. 
When the victualling is finished, when the Halicti no longer sally forth on harvesting intent nor return all floured over with their burden, the old Bee is still at her post, as vigilant as ever. The final preparations for the brood are made below; the cells are closed. The door is kept until everything is finished. Then grandmother and mothers leave the house. Exhausted by the performance of their duty, they go, somewhere or other, to die.

In September appears the second generation, comprising both males and fomales. 
THE LANGUEDOCIAN SCORPION 



\section{CHAPTER XVII}

\section{THE LANGUEDOCIAN SCORPION}

The Scorpion is an uncommunicative insect, occult in his manners and unpleasant to deal with, so much so that his history, apart from the findings of anatomy, is reduced to little or nothing. The scalpel of the masters has made us acquainted with his organic structure; but, so far as I know, no observer has thought of interviewing him, with any sort of persistence, on the subject of his private habits. Ripped up, after a preliminary maceration in alcohol, he is very well-known indeed; acting within the domain of his instincts, he is hardly known at all. And yet none of the segmented animals were more deserving of a detailed biography. He has at all times struck the popular imagination, even to the point of being numbered among the signs of the zodiac.

Fear made the gods, said Lucretius. Deified by terror, the Scorpion is glorified in the sky by a constollation and in the almanac by the symbol for the month of October. Let us try to make him speak.

Before housing my animals, let us give a brief description of them. The common Black Scorpion (Scorpio Europæus, Lin.), distributed over the greater part of South Europe, is known to all. He frequents the dark spots near our dwelling-places; on rainy days in autumn, he makes his way into our houses, sometimes even under 


\section{THE LIFE AND LOVE OF THE INSECT}

our bed-clothes. The hateful animal causes us more fright than damage. Although not unusual in my present abode, his visits have never had consequences of the least seriousness. The weird beast, overrated in reputation, is repulsive rather than dangerous.

IIuch more to be fearod and much less well-known generally is the Languedocian Scorpion, isolated in the Mediterranean provinces. Far from seeking our dwelling-houses, he keeps out of the way, in untilled solitudes. Beside the Black Scorpion, ho is a giant who, when full-grown, measures oight to nine centimetres in length. ${ }^{1}$ His colouring is that of pale, withered straw.

The tail, which is really the animal's belly, is a series of five prismatic joints, like little kegs whose staves meet in undulating ridges resembling strings of beads. Similar cords cover the arms and fore-arms of the claws and divide them into long facets. Others run sinuously along the back and imitate the joints of a cuirass, the pieces of which might have been collocted by a capricious milling-punch. These bead-like projections produce a fiercely robust armour, which is characteristic of the Languedocian Scorpion. It is as though the animal had becn fashioned out of chips with blows of the adze.

The tail ends in a sixth joint, which is vesicular and smooth. This is the gourd in which the poison, a formidable fluid resembling water in appearance, is elaborated and held in reserve. A curved, brown and very sharp sting ends the apparatus. A pore, visible only under the lens, opens at some distance from the point. Through this, the venomous humour is injected into the puncture. The sting is very hard and very sharp-pointed. Holding it between the tips of my fingers, I can push it through

13 to $3 \frac{1}{2}$ inches.-Translatur's Note. 
a sheet of cardboard as easily as though I were using a needle.

Owing to its powerful curve, the sting points downwards when the tail is held in a straight line. To use his weapon, the Scorpion must therefore raise it, turn it round and strike upwards. In fact, this is his invariable practice. The tail bends over the animal's back and comes forward before pinking the adversary held down with the claws. The animal, for that matter, is almost always in this posture: whether in motion or at rest, he curves his tail over his chine. He very rarely drags it slackened in a straight line.

The pincers, buccal hands suggesting the claws of the Crayfish, are organs of battle and information. When moving forwards, the animal holds them in front of him, with the fingers opened, to take stock of things encountered on the way. When he wants to stab, the claws catch the adversary and hold him motionless, while the sting operates above the assailant's back. Lastly, when he has to nibblo a morsel for any length of time, they serve as hands and keep the proy within reach of the mouth. They are never used for walking, for support or for the work of excavation.

That falls to the real legs. These are abruptly truncated and ond in a group of little curved, moveable claws, faced by a short, fine point, which, in a manner of speaking, serves as a thumb. The stump is finished off with rough bristles. The whole constitutes an excellent grapnel, which explains the Scorpion's capacity for roaming round the trellis-work of my wire bells, for standing there very long in a reversed position and, lastly, for clambering up a vertical wall, notwithstanding his clumsiness and awkwardness. 


\section{THE LIFE AND LOVE OF THE INSECT}

Below, immediately after the legs, are the combs, strange organs, an exclusive attribute of the Scorpions. They owe their name to their structure, consisting of a long row of scales arranged close together in the manner of the teeth of our ordinary combs. The anatomists are inclined to ascribe to these the functions of a gearingapparatus capable of keeping the couple connected at the moment of pairing.

In order to observe their domestic manners, I lodge my captives in a large glass volery, with big potsherds to serve them as a refuge. There are a couple of dozen Scorpions, all told. In April, when the Swallow returns to us and the Cuckoo sounds his first note, a revolution takes place among my hitherto peaceable Scorpions. Several of them, in the colonies which I have established in the open air, in my garden, go wandering about at night and do not return to their homes. A more serious matter : often, under the same piece of crockery, are two Scorpions, of whom one is in the act of devouring the other. Is it a matter of burglary among insects of the same order, who, falling into vagabond ways at the commencement of the fine weather, thoughtlessly enter their neighbours' houses and there meet with their undoing, unless they be the stronger? One would almost think it, so calmly is the intruder eaten up, for days at a time and by small mouthfuls, even as an ordinary prey would be.

Now here is something to give us a hint. The devoured are invariably of middling size. Their lighter shade of colouring, their less protuberant bellies mark them as males, always males. The others, larger, more paunchy, and a little darker in shade, do not ond in this unhappy fashion. So it is probably not a case of brawls betweon 


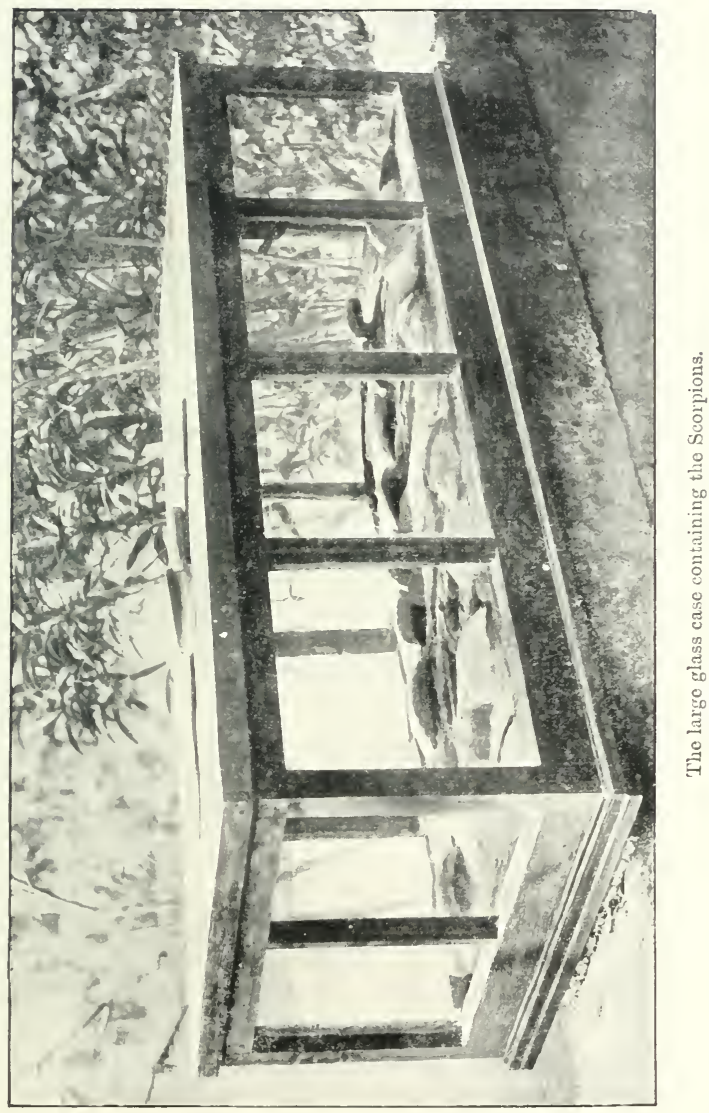



neighbours who, jealous of their solitude, soon settle the doom of any visitor and eat him afterwards, a radical means of putting a stop to further indiscretions; it is rather a question of nuptial rites tragically performod by the matron after pairing.

Spring returns once more. I have prepared the large glass cage in advance and peopled it with five-and-twenty inhabitants, each with his bit of earthenware. From mid-April onwards, every evening, towards night-fall, between seven and nine o'clock, great animation reigns within this crystal palace. That which seemed deserted by day now becomes a joyous scene. As soon as supper is finished, the whole household runs out to look at it. A lantern hung outside the panes allows us to follow events.

It is our diversion after the worries of the day; it is our play-house. In this theatre of simple folk, the performances are so interesting that, the moment the lantern is lighted, we all, old and young, come and take our seats in the pit : all, including even Tom, the house-dog. Tom, it is true, indifferont to Scorpion affairs, like the genuine philosopher that he is, lies down at our fect and dozes, but only with one eye, keeping the other always open on his friends, the children.

Let me try to give the reader an idea of what happens. A numerous assembly soon gathers near the glass panes in the zone discreetly lit by the lantern. Every elsewhere, here, there, single Scorpions walk about and, attracted by the light, leave the shade and hasten to the illuminated festival. The very moths betray no greater readiness to flutter to the rays of our lamps. The newcomers mingle with the crowd, while others, tired with their diversions, withdraw into the shade, snatch a few 
moments' rest and then impetuously return upon tho scene.

Theso hideous devotees of gaiety provido a dance not wholly unattractive. Somo come from afar : gravely they emerge from out the darkness; then, suddenly, with a rush as swift and easy as a slide, they join the crowd, in the light. Their agility reminds one of mice scudding with short steps. They seok one another and fly precipitately as soon as they touch, as though they had mutually burnt their fingers. Others, after tumbling about a little with their play-fellows, make off hurriedly, wildly. They take fresh courage in the dark and return.

At times, there is a brisk tumult: a confused mass of swarming legs, snapping claws, tails curving and clashing, threatening or fondling, it is hard to say which. In the affray, under favourable conditions, drouble specks light up and gleam like carbuncles. One would take them for eyes that shoot flashing glances; in reality they are two polished, reflecting facets, which occupy the front of the head. All, large and small alike, take part in the brawl ; it might be a battle to the death, a general massacre ; and it is just a wanton frolic. Even so do kittens bemaul each other. Soon, the group disperses; all make off from all sorts of places, without a scratch, without a sprain.

Behold the fugitives collecting once more before the lantern. They pass and pass again; they come and go, often meet front to front. He who is in the greatest hurry walks over the back of the other, who lets him have his way without any protest but a movement of the crupper. It is no time for blows: at most, two Scorpions meeting will exchange a cuff, that is to say, a rap of the caudal 
staff. In their socioty, this friendly thump, in which the point of the sting plays no part, is a sort of a fisticuff in frequent use.

There are better things than mingled legs and brandished tails : there are sometimes poses of the highest originality. Front to front and claws drawn back, two wrestlers assume the acrobat's "straight bend," that is to say, resting only on the fore-quarters, they raise the whole back of the body, so much so that the chest displays the four little lung-sacs uncovered. Then the tails, held vertically erect in a straight line, exchange mutual rubs, glide one over the other, while their extremities are hooked together and repoatedly fastened and unfastened. Suddenly, the friendly pyramid falls to pioces and each runs off hurriedly, without ceremony.

What were those two wrestlers trying to do, in their eccentric posture? Was it a set-to between two rivals? It would seem not, so peaceful is the encounter. My subsequent observations were to tell me that this was the mutual teasing of a betrothed couple. To declare his flame, the Scorpion does the straight bend.

To continue as I have begun and give a homogeneous picture of the thousand tiny particulars gathered day by day would have its adrantages: the story would be sooner told ; but, at the same time, deprived of its details, which vary greatly between one observation and tho next and are difficult to group, it would be less interesting. Nothing must be neglected in the relation of manners so strange and as yet so little known. At the risk of repeating one's self here and there, it is preferable to adhere to chronological order and to tell the story by fragments, as one's observations reveal fresh facts. Order will emerge from this disorder ; for each of the more remark- 


\section{THE LIFE AND LOVE OF THE INSECT}

able evenings supplies some feature that corroborates and completes those which go before. I will therefore continue my narration in the form of a diary.

25 April, 1904.-Hullo! What is this, which I have not yet seen? My eyes, ever on the watch, look upon the affair for the first time. Two Scorpions face each other, with claws outstretched and fingers clasped. It is a question of a friendly grasp of the hand and not the prelude of a battle, for the two partners behave to each other in the most peaceful way. There is one of either sex. One is paunchy and browner than the other: that is the female; the other is comparatively slim and pale: that is the male. With their tails prottily curled, the couple stroll with moasured steps along the pane. The male is ahead and walks backwards, without jolt or jerk, without any resistance to overcome. The female follows obediently, clasped by her finger-tips and face to face with her leader.

The stroll has halts that alter nothing in the manner of the tie ; it is resumed, now here, now there, from end to end of the enclosure. Nothing shows the object which the strollers have in view. They loiter, they dawdle, they most certainly exchange ogling glances. Even so, in my village, on Sundays, after vespers, do the youth of both sexes saunter along the hedges, every Jack with his Jill.

Often they tack about. It is always the male who decides which fresh direction the pair shall take. Without releasing her hands, he turns gracefully to the left or right about and places himself side by side with his companion. Then, for a moment, with his tail laid flat, he strokes her spine. The other stands motionless, impassive. 
For over an hour, without tiring, I watch these interminable comings and goings. A part of the household lends me its eyes in the presence of the strange sight which no one in the world has yet secn, at least with a vision capable of observing. In spite of the lateness of the hour, so upsetting to our habits, our attention is concentrated and no essential thing escapes us.

At last, at about ten o'clock, an event happens. The male has lit upon a potsherd the shelter of which seems to suit him. He releases his companion with one hand, with one alone, and, continuing to hold her with the other, he scratches with his legs and sweeps with his tail. A grotto opens. He enters and, slowly, without violence, drags the patient Scorpioness after him. Soon, both have disappeared. A plug of sand closes the dwelling. The couple are at home.

To disturb them would bo a blunder: I should be interfering too soon, at an inopportune moment, if I tried at once to see what was happening below. The preliminary stages may last for the bost part of the night; and it doos not do for me, who have turnod eighty, to sit up so late. I feel my legs giving way; and my eyes seem full of sand. Lot us go to sleep.

All night long, I dream of Scorpions. They crawl under my bed-clothes, they pass over my face; and I am not particularly excited, so many curious things do I see in my imagination. The next morning, at day-break, I raise the stoneware. The female is alone. Of the male there is no trace, either in the home or in the neighbourhood. First disappointment, to be followed by many others.

10 May.-It is nearly seven o'clock in the evening; the sky is overcast with signs of an approaching shower. 


\section{THE LIFE AND LOVE OF THE INSECT}

Under one of the potsherds is a motionless couple, faco to face, with linked fingers. Cautiously I raise the potsherd and leave the occupants uncovered, so as to study the results of the interviow at my ease. The darkness of the night falls and nothing, it seems to me, will disturb the calm of the home deprived of its roof. A brisk shower compels me to retire. They, under the lid of the cage, have no need to take shelter against the rain. What will they do, left to their business as they are, but deprived of a canopy to their alcove?

An hour later, the rain ceases and I return to my Scorpions. They are gone. They have taken up their abode under a neighbouring potsherd. Still with their fingers linked, the female is outside and the male indoors, preparing the home. At intervals of ten minutes, the members of my family rclieve one another, so as not to lose the exact moment of the pairing, which appears to me to be imminent. Useless cares : at eight o'clock, it being now quite dark, the couple, dissatisfied with the spot, set out on a fresh ramble, hand in hand, and go in search elsewhere. The male, walking backwards, leads the march, chooses the dwelling as he pleases; the female follows with docility. It is an exact repetition of what I saw on the 25th of April. At last, a tile is found to suit them. The male goes in first, but, this time, without letting go of his companion for a moment, with one hand or the other. The nuptial chamber is prepared with a few sweeps of the tail. Gently drawn towards him, the Scorpioness enters in the wake of her guide.

I visit them a couple of hours later, thinking that I have given them time enough to finish their preparations. I raise the potsherd. They are there in the same posture, 
face to face and hand in hand. I shall see no more to-day.

The next day, nothing new either. One in front of the other, meditatively, without stirring a limb, the gossips, holding each other by the finger-tips, continue their endless interview under the tile. In the evening, at sunset, after sitting linked together for four-andtwenty hours, the couple separate. He goes away from the tile, she remains; and matters have not advanced by an inch.

This observation gives us two facts to remember. After the stroll to celebrate the betrothal, the couple need the mystery and quiet of a shelter. Never would the nuptial conclusion take place in the open air, amid the bustling crowd, in sight of all. Remove the roof of the house, by night or day, with all possible discretion; and the husband and wife, who seem absorbed in meditation, march off in search of another spot. Also, the stay under the cover of a stone is a long one: we have just seen it spun out to twenty-four hours and even then without a decisive result.

12 May.-What will this evening's watch teach us? The weather is ealm and hot, favourable to nocturnal pastimes. A couple has formed: I did not witness the start. This time the male is greatly inferior in size to his corpulent mate. Nevertheless, the skinny wight performs his duty gallantly. Walking backwards, according to rule, with his tail rolled trumpetwise, he marches the fat Scorpioness around the glass ramparts. After one circuit follows another, sometimes in the same, sometimes in the opposite direction.

Stops are frequent. Then the two foreheads touch, bend a little to left and right, as if there were whispers 


\section{THE LIFE AND LOVE OF THE INSECT}

exchanged in each other's ears. The little fore-legs flutter in fevered caresses. What are they saying to each other ? How shall we translate their silent epithalamium into words?

The whole household turns out to see this curious group, which our presence in no way disturbs. The pair are pronounced to be "pretty"; and the expression is not exaggerated. Semi-translucent and shining in the light of the lantern, they seem carved out of a block of yellow amber. Their arms outstretched, their tails rolled into graceful volutes, they wander on with a slow movement and with measured tread.

Nothing puts them out. Should some vagabond, taking the evening air and keeping to the wall like themselves, meet them on their way, he stands aside-for he understands these delicate matters-and leaves them a free passage. Lastly, the shelter of a tile receives the strolling pair, the male entering first and backwards: that goes without saying. It is nine o'clock.

The idyll of the evening is followed, during the night, by a hideous tragedy. Next morning, we find the Scorpioness under the potsherd of the previous day. The little male is by her side, but slain and more or less devoured. He lacks the head, a claw, a pair of legs. I place the corpse in the open, on the threshold of the home. All day long, the recluse does not touch it. When night returns, she goes out and, meeting the defunct on her passage, carries him off to a distance to give him a decent funeral, that is to finish eating him.

This act of cannibalism agrees with what the open-air colony showed me last year. From time to time, I would find, under the stones, a pot-bellied female making a comfortable ritual meal off her companion of the night. 
I suspected that the male, if he did not break loose in time, once his functions were fulfilled, was devoured, wholly or partly, according to the matron's appetite. I now have the certain proof before my eyes. Yesterday, I saw the couple enter their home after the usual preliminary, the stroll; and, this morning, under the same tile, at the moment of my visit, the bride is consuming her mate.

We are entitled to believe that the poor wretch has attained his ends. Were he still necessary to the brood, he would not yet be eaten. The actual couple have therefore been quick about the business, whereas I see others fail to finish after provocations and contemplations exceeding in duration the time which it takes the hourhand to go twice round the clock. Circumstances which it is impossible to state with precision-the condition of the atmosphere, perhaps, the electric tension, the temperature, the individual ardour of the couple-to a large extent accelerate or delay the finale of the pairing; and this is what constitutes the serious difficulty for the observer anxious to scize the exact moment whereat the as yet uncertain function of the combs might be revealed. 14 May.-It is certainly not hunger that sets my animals in commotion night after night. The quest of food has nothing to say to their evening rounds. I have served up a varied bill of fare to the busy crowd, a fare chosen from that which they appear to like best. It includes tender morsels in the shape of young Crickets; small Locusts, fleshier and in better condition than the Acridians ; Moths minus their wings. In a more advanced season, I add Dragon-flies, a highly-appreciated dish, as is proved by their equivalent, the full-grown Ant-lion, of whom I often find the scraps, the wings, in the Scorpions' cave. 


\section{THE LIFE AND LOVE OF THE INSECT}

This luxurious game leaves them indifferent; none of them pays attention to it. Amid the hubbub, the Crickets hop, the Moths beat the ground with the stumps of their wings, the Dragon-flies quiver; and the passers-by take no notice. They tread them underfoot, they topple them over, they push them away with a stroke of the tail; in short, they absolutely refuse to look at them. They have other business in hand.

Almost all of them move along the glass wall. Some of them obstinately attempt to scale it : they hoist themselves on their tails, fall down, try again elsewhere. With their outstretched fists they knock against the pane; they want to get away at all costs. And yet the grounds are large enough, there is room for all ; the walks 1.nd themselves to long strolls. No matter: they want to roam afar. If they were free, they would disperse in every direction. Last year, at the same time, the colonists of the enclosure left the village and I never saw them again.

The spring pairing-season enjoins journeys upon them. The shy hermits of yesterday now leave their cells and go on love's pilgrimage ; heedless of food, they set out in quest of their kind. Among the stones of their territory there must be choice spots at which meetings take place, at which assemblies are held. If I were not afraid of breaking my logs, at night, over the rocky obstacles of their hills, I should love to assist at their matrimonial festivals, amid the delights of liberty. What do they do up there, on their bare slopes? Much the same, apparently, as in the glass enelosure. Having made their choice of a bride, they take her about, for a long stretch of time, hand in hand, through the tufts of lavender. If they miss the attractions of my lantern, 
they have the moon, that incomparable lamp, to light them.

20 May. - The sight of the first invitation to a stroll is not an event upon which we can count every evening. Several emerge from under their stones already linked in couples. In this concatenation of clasped fingers, they have passed the whole day, motionless, one in front of the other and meditating. When night comes, they resume, without separating for a moment, the walk around the glass begun on the evening before, or even earlier. No one knows when or how the junction was effected. Others meet unawares in sequestered passages difficult of inspection. By the time that I see them, it is too late: the equipage is on the way.

To-day, chance favours me. The acquaintance is made before my eyes, in the full light of the lantern. A frisky, sprightly male, in his hurried rush through the crowd. suddenly finds himself face to face with a passer-by who takes his fancy. She does not say no; and things go quickly.

The foreheads touch, the claws work; the tails swing with a wide movement: they stand up vertically, hook together at the tips and softly stroke each other with a slow caress. The two animals perform the acrobat's "straight bend," in the manner already described. Soon, the raised bodies collapse; fingers are clasped and the couple starts on its stroll without more ado. The pyramidal pose, therefore, is really the prelude to the harnessing. The pose, it is true, is not rare between two individuals of the same sex who meet; but it is then less correct and, above all, less marked by ceremony. At such times, we find movements of impatience, instead of friendly excitations; the tails strike in lieu of caressing each other. 
Let us watch the male, who hurries away backwards, very proud of his conquest. Other females are met, who form an audience and look on inquisitively, perhaps enviously. One of them flings herself upon the ravished bride, embraces her with her legs and makes an effort to stop the equipage. The male exhausts himself in attempts to overcome this resistance; in vain he shakes, in vain he pulls : the thing won't go. Undistressed by the accident, he throws up the game. A neighbour is there, close by. Cutting parley short, this time without any further declaration, he takes her hands and invites her to a stroll. She protests, releases herself and runs away.

From among the group of onlookers, a second is solicited, in the same free and easy manner. She accepts, but there is nothing to tell us that she will not escape from her seducer on the way. But what does the coxcomb care? There are more where she came from! And what does he want, when all is said? The firstcomer !

This first-comer he ends by finding, for here he is, leading his conquest by the hand. He passes into the belt of light. Exerting all his strength, he makes jerky movements of drawing towards him, if the other refuse to come, but behaves with gentleness, when he obtains a docile obedience. Pauses, sometimes rather prolonged, are frequent.

Then the male indulges in curious exercises. Bringing his claws, or let us say, his arms towards him and then again stretching them straight out, he compels the female to play a similar alternate game. The two of them form a system of jointed rods, or lazy-tongs, opening and closing their quadrilateral turn and turn about. After this 
gymnastic drill, the mechanism contracts and remains stationary.

The foreheads now touch; the two mouths come together with tender effusions. The word "kisses" comes to one's mind to express these caresses. It is not applicable; for head, face, lips, cheeks, all are missing. The animal, clipped as though with the pruning shears, has not even a muzzle. Where we look for a face we are confronted with a dead wall of hideous jaws.

And to the Scorpion this represents the supremely beautiful! With his fore-legs, more dclicate, more agile than the others, he pats the horrible mask, which in his eyes is an exquisite little face; voluptuously he gnaws and tickles with his lower jaws the equally hideous mouth opposite. It is all superb in its tenderness and simplicity. The Dove is said to have invented the kiss. But I know that he had a fore-runner in the Scorpion.

Dulcinea lots her admirer have his way and remains passive, not without a secret longing to slip off. But how is she to set about it? It is quite easy. The Scorpioness makes a cudgel of her tail and brings it down with a bang upon the wrists of her too-ardent wooer, who there and then lets go. The match is broken off, for the time being. To-morrow, the sulking-fit will be over and things will resume their course.

25 May.-This blow of the cudgel teaches us that the docile companion revealed by the first observations is capable of whims, of obstinate refusals, of sudden divorces. Let us give an example.

This evening, he and she, a seemly couple, are out for a stroll. A tile is found and appears to suit. Letting go with one claw, so as to have some freedom of action, the male works with his legs and tail to clear the entrance. 
He goes in. By degrees, as the dwelling is dug out, the female follows him, meekly and gently, so one would think.

Soon, the place and time perhaps not suiting her, she rcappears and half-emerges, backwards. She struggles against her abductor, who, on his side, pulls her to him, without, as yet, showing himself. A lively contest ensucs, one making every effort outside the cabin, the other inside. They go backwards and forwards by turns ; and success is undecided. At last, with a sudden exertion, the Scorpioness drags her companion out.

The unbroken team is in the open; the walk is resumed. For a good hour, they veer to one side along the pane, veer back to the other and then return to the tile of just now, to the exact same tile. As the way is already open, the male enters without delay and pulls like mad. Outside, the Scorpioness resists. Stiffening her legs, which plough the soil, and buttressing her tail against the arch of the tile, she refuses to go in. I like this resistance. What would the pairing be without the playful toying of the preludes?

Under the stone, however, the ravisher insists and contrives to such good purpose that the rebel obeys. She enters. It has just struck ten. If I have to sit up for the rest of tho night, I will wait for the result; I shall turn the potsherd at the fitting moment to catch a glimpse of what is happening underneath. Good opportunities are rare : let us make the most of this one. What shall I see?

Nothing at all. In half an hour or less, the refractory one frees herself, issues from the shelter and flees. The other at once runs up from the back of the cabin, stops on the threshold and looks out. His beauty has escaped 
PLATE XI

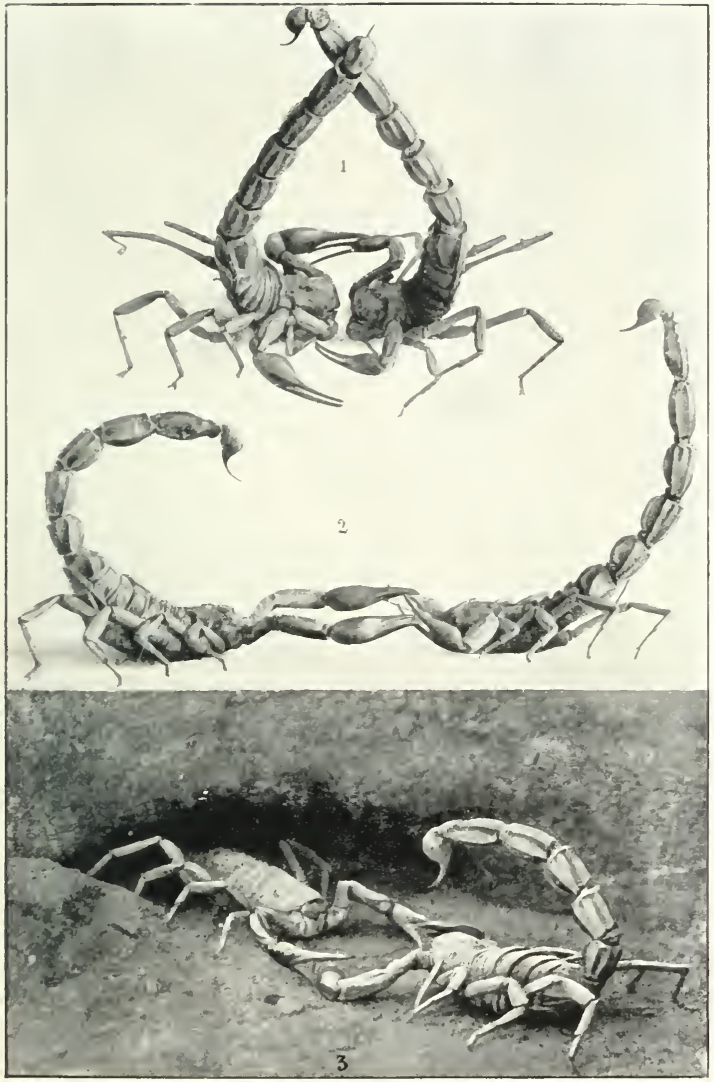

1. Nuptial allurements, showing " the straight bend."

2. The wedding stroll.

3. The couple enter the nuptial dwelling. 

him. He has been jilted. Sheepishly, he returns indoors. I follow his example.

June sets in. For fear of a disturbance caused by too brilliant an illumination, I have hitherto kept the lantern hung outside, at some distance from the pane. The insufficient light does not allow me to observe certain details as to the manner in which the couple are linked when strolling. Do they both play an active part in the scheme of the clasped hands? Are their fingers interlinked alternately? Or does only one of the pair act; and, if so, which? Let us ascertain exactly; the thing is not without importance.

I place the lantern inside, in the centre of the cage. There is a good light everywhere. Far from being scared, the Scorpions gain in gladness. They hasten up around the beacon ; some even try to climb it, so as to be nearer the flamo. They succeed in doing so by means of the frames containing the glass squares. They hang on to the edges of the tin strips and stubbornly, heedless of slipping, end by reaching the top. There, motionless, lying partly on the glass, partly on the support of the metal casing, they gaze the whole evening long, fascinated by the glory of the wick. They remind me of the Great Peacock Moths that used to hang in ecstasy under the reflector of my lamp.

At the foot of the beacon, in the full light, a couple loses no time in doing the straight bend. The two fence prettily with their tails and then go a-strolling. The male alone acts. With the two fingers of each claw, he has seized the two fingers of the corresponding claw of the Scorpioness in a bunch. He alone exerts himself and squeezes; he alone is at liberty to break the team when he likes: he has but to open his pincers. The 


\section{THE LIFE AND LOVE OF THE INSECT}

female cannot do so; she is a prisoner, handcuffed by her seducer.

In rather infrequent cases, one can see even finer things. I have caught the Scorpion dragging his sweetheart by the two fore-arms; I have seen him pull her by one leg and by the tail. She had resisted the advances of the outstretched hand ; and the bully, forgetful of all reserve, had thrown her on her side and clawed hold of her at random. The thing is quite clear: we have to do with a regular rape, abduction with violence. Even so did Romulus' youths rape the Sabine women. 


\section{CHAPTER XVIII}

THE LANGUEDOCIAN SCORPION : THE FAMILY

BooK-KNOWLEDGE is a poor resource in the problems of life; assiduous converse with facts is preferable here to the best-stocked library. In many cases, ignorance is a good thing : the mind retains its freedom of investigation and does not stray along roads that lead nowhither, suggested by one's reading. I have experienced this once again.

An anatomical monograph-the work, indeed, of a master-had told me that the Languedocian Scorpion is big with young in September. Oh, how much better should I have done not to consult it! The thing happens much earlier, at least in my part of the country ; and, as the rearing does not last long, I should have scen nothing, had I tarried for September. A third year of observation, tiresome to wait for, would have become necessary, in order at last to witness a sight which I foresaw to be of the highest interest. But for exceptional circumstances, I should have allowed the fleeting opportunity to pass, lost a year and perhaps even abandoned the subject.

Yes, ignorance can have its advantages; the now is found far from the beaten track. One of our most illustrious masters, little suspecting the lesson he was giving me, taught me that some time since. One fine day, Pasteur rang unexpectedly at my front-door : the same 


\section{$2 \div 4$ THE LIFE AND LOVE OF THE INSECT}

who was soon to acquire such world-wide celebrity. His name was familiar to me. I had read the scholar's fine work on the dissymetry of tartaric acid; I had followed with the greatest interest his researches on the generation of Infusoria.

Each period has its scientific crotchet : to-day, we have transformism; at that time, they had spontaneous generation. With his balloons made sterile or fecund at will, with his experiments so magnificent in their severity and simplicity, Pasteur gave the death-blow to the lunacy which pretended to see life springing from a chemical conflict in the seat of putrefaction.

In the midst of this contest so victoriously elucidated, I welcomed my distinguished visitor as best I could. The savant came to me first of all for certain particulars. I owed this signal honour to my standing as his eolleague in physics and chemistry. Oh, such a poor, obscure colleague !

Pasteur's tour through the Avignon region had sericiculture for its object. For some years, the silk-worm nurseries had been in confusion, ravaged by unknown plagues. The worms, for no appreciable reason, were falling into a putrid deliquescence, hardening, so to speak, into plaster sugar-plums. The downcast peasant saw one of his chief crops disappearing; after much care and trouble, he had to fling his nurseries on the dung-heap.

A few words were exchanged on the prevailing blight; and then, without further preamble, my visitor said:

"I should like to see some cocoons. I have never seen any ; I know them only by name. Could you get me some?"

"Nothing easier. My landlord happens to sell cocoons; and he lives in the next house. If you will wait a moment, I will bring you what you want." 
Four steps took me to my neighbour's, where I crammed my pockets with cocoons. I came back and handed them to the savant. He took one, turned and turned it between his fingers; he examined it curiously, as one would a strange object from the other end of the world. He put it to his ear and shook it :

"Why, it makes a noise!" he said. quite surprised. "There's something inside!"

"Of course there is."

"What is it?"

"The chrysalis."

"How do you mean, the chrysalis?"

"I mean the sort of mummy into which the caterpillar changes before becoming a moth."

"And has every cocoon one of those things inside it?"

"Obviously. It is to protect the chrysalis that the caterpillar spins."

"Really!"

And, without more words, the cocoons passed into the pocket of the savant, who was to instruct himself at his leisure touching that great novelty, the chrysalis. I was struck by this magnificent assurance. Pasteur had come to regenerate the silk-worm. while knowing nothing about caterpillars, cocoons, chrysalises or metamorphoses. The ancient gymnasts came naked to the fight. The talented combatant of the plague of our silk-worm nurseries hastened to the battle likewise naked, that is to say, destitute of the simplest notions about the insect which he was to deliver from danger. I was staggered; nay, more, I was wonderstruck.

I was not so much amazed by what followed. Pasteur was occupied at the time with another question, that 


\section{THE LIFE AND LOVE OF THE INSECT}

of the improrement of wine by heating. Suddenly changing the conversation :

"Show me your cellar," he said.

I! I show my cellar, my private cellar, poor I, who, in those days, with my pitiful teacher's salary, could not indulge in the luxury of a little wine and brewed myself a sort of small cider by setting a handful of moist sugar and some apples already stoeped in spoilt cider to ferment in a cask! My cellar! Show my cellar! Why not my barrels, my cobwebbed bottles, each labelled with its age and vintage! My cellar !

Full of confusion, I avoided the request and tried to turn the conversation. But he persisted :

"Show me your cellar, please."

There was no resisting such firmness. I pointed with my finger to a corner in the kitchen where stood a chair with no seat to it; and, on that chair, a demi-joln containing two or three gallons :

"That's my cellar, sir."

"Is that your cellar?"

"I have no other."

"Is that all?"

"Yes, that is all. alas!"

"Really !"

Not a word more; nothing further from the savant. Pasteur, that was evident, had never tasted the highlyspiced dish which the vulgar call la vache enragée. Though my cellar-the dilapidated chair and the more than halfempty demi-john-said nothing about the fermentation to be combated by heating, it spoke eloquently of another thing which my illustrious visitor seemed not to understand. A microbe escaped from it and a very terrible microbe : that of ill-fortune strangling good-will. 
In spite of the unlucky introduction of the cellar, I remain none the less struck by his serene assurance. He knows nothing of the transformation of insects; he has just seen a cocoon for the first time and learnt that there is something inside that cocoon, the rough draft of the moth that shall be; he is ignorant of what is known to the meanest school-boy of our southern parts; and this novice, whose artless questions surprise me so greatly, is about to revolutionize the hygiene of the silk-worm nurseries. In the same way, he will rerolutionize medicine and general hygiene.

His weapon is thought, heedless of details and soaring over the whole question. What cares he for metamorphoses, larvæ, nymphæ, cocoons, pupæ, chrysalises and the thousand and one little secrets of entomology ! For the purposes of his problem, perhaps, it is just as well to be ignorant of all that. Ideas retain their independence and their daring flight more easily ; movements are freer, when released from the leading-strings of the known.

Encouraged by the magnificent example of the cocoons rattling in Pasteur's astonished ears, I have made it a rule to adopt the method of ignorance in my investigations into instincts. I read very littlo. Instead of turning the pages of books, an expensive proceeding quite beyond my means, instead of consulting other people, I persist in obstinately interviewing my subject until I succeed in making him speak. I know nothing. So much the better : my queries will be all the freer, now in this direction, now in the opposite, according to the lights obtained. And if, by chance, I do open a book, I take care to leave a pigcon-hole in my mind wide open to doubt; for the soil which 1 am clearing bristles with weeds anic: brambles. 
For lack of taking this precaution, I very nearly lost a year. Relying on what I had read, I did not look for the family of the Languedocian Scorpion until September ; and I obtained it quite unexpectedly in July. This difference between the real and the anticipated date I ascribe to the disparity of the climate: I make my obscrvations in Provence and my informant, Léon Dufour, made his in Spain. Notwithstanding the master's high authority, I ought to have been on my guard. I was not; and I should have lost the opportunity if, as luck would have it, the Common Black Scorpion had not taught me. Ah, how right was Pasteur not to know the chrysalis !

The Common Scorpion, smaller and much less active than the other, was brought up, for purposes of comparison, in humble glass jars that stood on the table in my study. The modest apparatus did not take up much room and were easy to examine; and I made a point of visiting them daily. Every morning, before sitting down to blacken a fow pages of my diary with prose, I invariably lifted the piece of cardboard which I used to shelter my boarders and enquired into the happenings of the night. These daily visits were not so feasible in the large glass cage, whose numerous dwellings required a general overthrow, if they were to be examined one by one and then methodically replaced in condition as discovered. With my jars of Black Scorpions, the inspection was the matter of a moment.

It was well for me that I always had this auxiliary establishment before my eyes. On the 22nd of July, at six o'clock in the morning, raising the cardboard screen, I found the mother beneath it, with her little ones grouped on her chine like a sort of white mantlet. I experienced 
one of those seconds of sweet contentment which, at intervals, reward the long-suffering observer. For the first time, I had before my eyes the fine spectacle of the Scorpioness clad in her young. The delivery was quite recent; it must have taken place during the night; for, on the previous evening, the mother was bare.

Further successes awaited me: on the next day, a second mother is whitened with her brood; the day after that, two others at a time are in the same condition. That makes four. It is more than my ambition hoped for. With four families of Scorpions and a few quiet days before me, I can find sweets in life.

All the more so as fortune loads me with her farours. Ever since the first discovery in the jars, I have been thinking of the glass cage and asking myself whether the Languedocian Scorpion might not be as precocious as her black sister. Let us go quick and see.

I turn over the twenty-five tiles. A glorious success! I feel one of those hot waves of enthusiasm with which I was familiar at twenty rush through my old veins. Under three of the lot of tiles, I find a mother burdened with her family. One has little ones already shooting up, about a week old, as the sequel of my observations informed me; the two others have borne their children recently, in the course of last night, as is proved by certain remnants jealously guarded under the paunch. We shall see presently what those remnants represent.

July runs to an end, August and September pass and nothing more occurs to swell my collection. The period of the family, therefore, for both Scorpions is the second fortnight in July. From that time onward, everything is finished. And yet, among my guests in the glass cage, there remain females as big and fat as those 
from whom I have obtained an offspring. I reckoned on these too for an increase in the population ; all the appearances authorized me to do so. Winter comes and none of them has answered my expectations. The business, which secmed close at hand, has been put off to next year : a fresh proof of long pregnancy, very singular in the case of an animal of an inferior order.

I transfer each mother and her product, separately, into medium-sized receptacles, which facilitate the niceties of the observation. At the early hour of my visit, those brought to bed during the night have still a part of the brood sheltered under their belly. Pushing the mother aside with a straw, I discover, amid the heap of young not yet hoisted on the maternal back, objects that utterly upset all that the books have taught me on this subject. The Scorpions, they say, are viviparous. The learned expression lacks exactitude: the young do not see the light directly with the formation which we know of.

And this must be so. How would you have the outstretched claws, the sprawling legs, the shrivelled tails go through the maternal passages? The cumbrous little animal could never pass through the narrow outlets. It must needs come into the world packed up and sparing of space.

The remnants found under the mothers, in fact, show me eggs, real eggs, similar, or very nearly, to those which anatomy extracts from the ovaries at an advanced stage of pregnancy. The little animal, economically compressed to the dimensions of a grain of rice, has its tail laid along its belly, its claws flattened against its chest, its legs pressed to its sides, so that the small, easy-gliding, oval lump leaves not the smallest protuberance. On the forehead, dots of an intense black mark the eyes. Tho 
tiny insect floats in a drop of transparent moisture, which is for the moment its world, its atmosphere, contained by a pellicle of exquisite delicacy.

These objects are really eggs. There were thirty or forty of them, at first, in the Languedocian Scorpion's litter ; not quite so many in the Black Scorpion's. Interfering too late in the nocturnal lying-in, I am present at the finish. The little that remains, however, is sufficient to convince me. The Scorpion is in reality oviparous; only her eggs hatch very speedily and the liberation of the young follows very soon after the laying.

Now how does this liberation take place? I enjoy the remarkable privilege of witnessing it. I see the mother with the point of her mandibles delicately seizing, lacerating, tearing off and lastly swallowing the membrane of the egg. She strips her new-born offspring with the fastidious care and fondness of the sheep and the cat when eating the fetal wrappers. Not a scratch on that scarceformed flesh, not a strain, in spite of the clumsiness of the tool employed.

I cannot get over my surprise : the Scorpion has initiated the living into acts of maternity bordering on our own. In the distant days of the coal vegetation, when the first Scorpion appeared, the gentle passions of childbirth were already preparing. The egg, the equivalent of the long-sleeping seed, the egg, as already possessed by the reptile and the fish and later to be possessed by the bird and almost the whole body of insects, was the contemporary of an infinitely more delicate organism which ushered in the viviparousness of the higher animals. The incubation of the germ did not take place outside, in the heart of the threatening conflict of things ; it was accomplished in the mother's womb. 


\section{THE LIFE AND LOVE OF THE INSECT}

The progressive movements of life know no gradual stages, from fair to good, from good to excellent; they proceed by leaps and bounds, in some cases advancing, in some recoiling. The ocean has its ebb and flow. Life, that other ocean, more unfathomable than the ocean of the waters, has its ebb and flow likewise. Will it have any others? Who can say that it will? Who can say that it will not?

If the sheep were not to assist by swallowing the wrappers after picking them up with her lips, never would the lamb succeed in extricating itself from its swaddlingclothes. In the same way, the little Scorpion calls for its mother's aid. I see some that, cuught in stickiness, move about helplessly in the half-torn ovarian sac and are unable to free themselves. It wants a touch of the mother's teeth to complete the deliverance. It is doubtful even whether the young insect contributes to effect the laceration. Its weakness is of no avail against that other weakness, the natal envelope, though this be as slender as the inner integument of an onion-skin.

The young chick has a temporary callosity at the end of its beak, which it uses to peck, to break the shell. The young Scorpion, condensed to the dimensions of a grain of rice to economize space, waits inertly for help from without. The mother has to do everything. She works with such a will that the accessories of childbirth disappear altogether, even the few sterile eggs being swept away with the others in the general flow. Not a remnant lingers behind of the now useless tatters; everything has returned to the mother's stomach ; and the spot of ground that has received the laying is swept absolutely clear.

So here we have the young nicely wiped, clean and free. They are white. Their length, from the forehead to the 


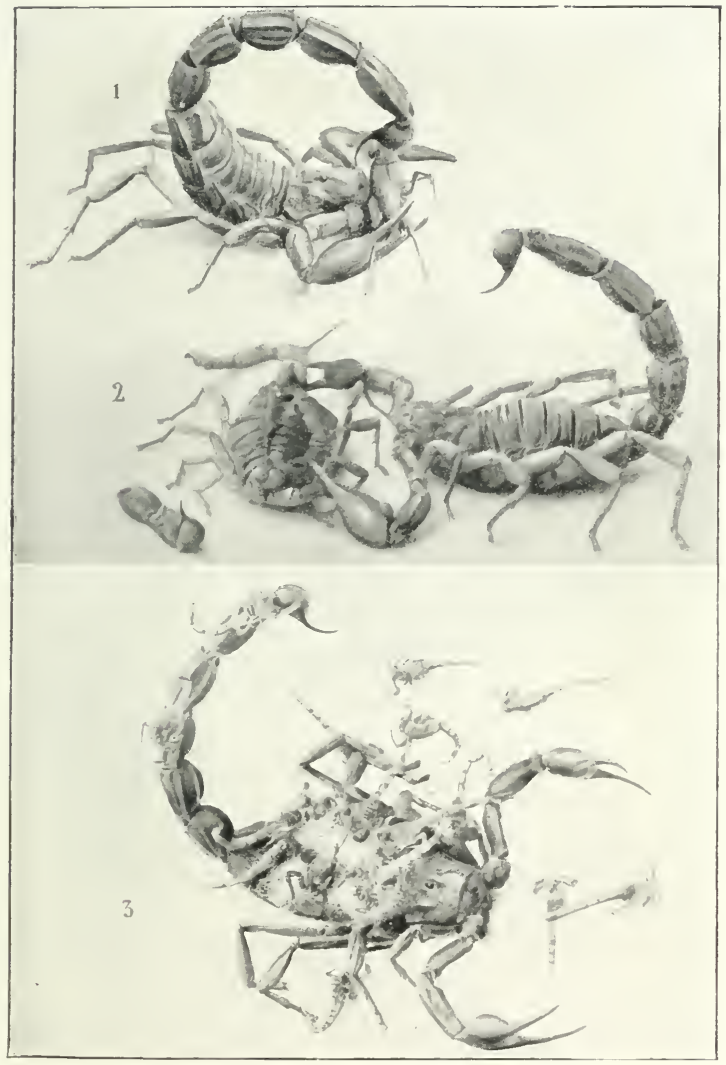

1. The Languedocian Scorpion devouring a cricket.

2. After pairing-time: the female feasting on her Scorpion.

3. The mother and her family, with emancipation-time at band. 

tip of the tail, measures nine millimetres ${ }^{1}$ in the Languedocian Scorpion and four ${ }^{2}$ in the Black. As the liberating toilet is completed, they climb, first one and then the other, on the maternal spine, hoisting themselves, without excessive haste, along the claws, which the Scorpion keeps flat on the ground, in order to facilitate the ascent. Close-grouped one against the other, entangled at random, they form a continuous cloth on the mother's back. With the aid of their little claws, they are pretty firmly settled. One finds some difficulty in sweeping them away with the point of a hair pencil without more or less hurting the feeble creatures. In this state, neither steed nor burden budges : it is the fit moment for experimenting.

The Scorpion, clad in her young assembled to form a white muslin mantlet, is a spectacle worthy of attention. She remains motionless, with her tail curled on high. If I bring a rush of straw too near the family, she at once lifts her two claws in an angry attitude, rarely adopted in her own defence. The two fists are raised in a sparring posture, the nippers open wide, ready to thrust and parry. The tail is seldom brandished: to loosen it suddenly would give a shock to the spine and perhaps make a part of the burden fall to the ground. The bold, sudden, imposing menace of the fists suffices.

My curiosity takes no notice of it. I push off one of the little ones and place it facing its mother, at a finger's breadth away. The mother does not seem to trouble about the accident: motionless she was, motionless she remains. Why excite herself about that slip? The fallen child will be quite able to manage for itself. It gesticulates, it moves about; and then, finding one of

1.35 inch. - Translator's Note.

'15 inch. - Translator's Note. 


\section{THE LIFE AND LOVE OF THE INSECT}

the maternal claws within its reach, it clambers up pretty nimbly and joins the crowd of its brothers. It resumes its seat in the saddle, but without, by a long way, displaying the agility of the Lycosa's sons, who are expert riders, versed in the art of vaulting on horseback.

The test is repeated on a larger scale. This time, I sweep a part of the load to the ground; the little ones are scattered, to no very great distance. There is a somewhat prolonged moment of hesitation. While the brats wander about, without quite knowing where to go, the mother at last becomes alarmed at the state of things. With her two arms-I am speaking of the chelæ-with her two arms joined in a semi-circle, she rakes and gathers the sand so as to bring the strayers to her. This is done awkwardly, clumsily, with no precautions against accidental crushing. The Hen, with a soft clucking call, makes the wandering chicks return to the pale; the Scorpion collects her family with a sweep of the rake. All are safe and sound nevertheless. As soon as they come in contact with the mother, they climb up and form themselves again into a dorsal group.

Strangers are admitted to this group, as well as the legitimate offspring. If, with the camel-hair broom, I dislodge a mother's family, wholly or in part, and place it within reach of a second mother, herself carrying her family, the latter will collect the young ones by armfuls, as she would her own offspring, and very kindly allow the newcomers to mount upon her back. One would say that she adopts them, were the expression not too ambitious. There is no adoption. It is the same blindness as that of the Lycosa, who is incapable of distinguishing between her own family and the family of others, and riclcomes all that swarms about her legs. 
I expected to come upon excursions similar to those of the Lycosa, whom it is not unusual to meet scouring the heath with her pack of children on her back. The Scorpion knows nothing of these diversions. Once she becomes a mother, for some time she does not leave her home, not even in the evening, at the hour when others sally forth to frolic. Barricaded in her cell, not troubling to eat, she watches over the upbringing of her young.

As a matter of fact, those frail creatures have a delicate test to undergo : they have, one might say, to be born a second time. They prepare for it by immobility and by an inward labour not unlike that which turns the larva into the perfect insect. In spite of their fairly correct appearance as Scorpions, the young ones have rather indistinct features, which look as though seen through a mist. One is inclined to credit them with a sort of child's smock, which they must throw off in order to become slim and acquire a definite shape.

Eight days spent without moving, on the mother's back, are necessary to this work. Then there takes place an excoriation which I hesitate to describe by the expression "casting of the skin," so greatly does it differ from the true casting of the skin, undergone later at repeated intervals. For the latter, the skin splits over the thorax; and the animal emerges through this single fissure, leaving a dry cast garment behind it, similar in shape to the Scorpion that has just thrown it off. The empty mould retains the exact outline of the moulded animal.

But, this time, it is something different. I place a few young ones in course of excoriation on a sheet of glass. They are motionless, sorely tried, it seems, almost spent. The skin bursts, without special lines of cleavage; it tears at one and the samo time in front, behind, at the 
sides; the legs come out of their gaiters, the claws leave their gauntlets, the tail quits its scabbard. The cast skin falls in rags on every side at a time. It is a flaying without order and in tatters. When it is done, the flayed insects present the normal appearance of Scorpions. They have also acquired agility. Although still pale in tint, they are nimble, quick to set foot to earth in order to run and play near the mother. The most striking part of this progress is the brisk growth. The young of the Languedocian Scorpion measured nine millimetres in length ; they now measure fourteen. ${ }^{1}$ Those of the Black Scorpion have grown from four to six or seven millimetres. ${ }^{2}$ The length increases by one half, which nearly trebles the volume.

Surprised at this sulden growth, one asks one's self what the cause can be ; for the little ones have taken no food. The weight has not increased : on the contrary, it has diminished; for we must remember that the skin has been cast. The volume grows, but not the bulk. It is therefore a distension up to a certain point and may be compared with that of inorganic bodies under the influence of heat. A secret change takes place, which groups the living molecules into a more spacious combination; and the volume increases without the addition of fresh materials. One who, possessed of a fine patience and suitably equipped, cared to follow the rapid changes of this architecture would. I think, reap a harvest of some value. I, in my penury, abandon the problem to others.

The remains of the excoriation are white strips, silky rags, which, so far from falling to the ground, attach them-

$1 \cdot 35$ increased to $\cdot 55$ inch.-T'ranslator's Note.

$2 \cdot 15$ increased to $\cdot 235$ or $\cdot 2$ 'i5 inch.-Translator's Note. 
selves to the back of the Scorpion, especially near the basal segments of the legs, and there tangle themselves into a soft carpet on which the lately-flayed insects rest. The steed now carries a saddle-cloth well-adapted to hold her restless riders in position. Whether these have to alight or to remount, the layer of tatters, now become a solid harness, affords supports for rapid evolutions.

When I topple over the family with a slight stroke of the camel-hair pencil, it is amusing to see how quickly the unhorsed ones resume their seat in the saddle. The fringes of the housings are grasped, the tail is used as a lever and, with a bound, the horseman is in his place. This curious carpet, a real boarding-netting which allows of easy scaling, lasts, without dislocations, for nearly a week, that is to say, until the emancipation. Then it comes off of its own accord, either as a whole or piecemeal, and nothing remains of it when the young are scattcrod around.

Meantime, signs of the colouring appear; the tail and belly are tinged with saffron, the claws assume the soft brilliancy of transparent amber. Youth beautifies all things. The little Languedocian Scorpions are really splendid. If they remained thus, if they did not carry a poison-still, soon to become threatening, they would bo pretty creatures which one would find a pleasure in rearing. Soon the wish for emancipation awakens in them. They gladly descend from the mother's back to frolic merrily in the neighbourhood. If they stray too far, the mother cautions them and brings them back again by sweeping the rake of her arms over the sand.

At dozing-time, the sight furnished by the Scorpioness is almost as good as that of the hen and her chicks resting. 


\section{THE LIFE AND LOVE OF THE INSECT}

Nost of the young ones are on the ground, pressed close against the mother; a few are stationed on the white saddle-cloth, a delightful eushion. There are some who elamber up the mother's tail, pereh on the top of the bend and seem to delight in looking down from that point of vantage upon the crowd. More aerobats arrive, who dislodge them and take their places. All want their share in the euriosities provided by the gazebo.

The bulk of the family is around the mother; there is a constant swarm of brats that erawl under the belly and there squat, leaving their forehead, with the gleaming black eye-points, outside. The more restless prefer the mother's legs, which to them represent a gymnasium; they here swing as on a trapeze. Next, at their leisure, the whole troop elimb up to the spine again, resume their places, settle down; and nothing more stirs, neither mother nor little ones.

This period wherein the emaneipation is matured and prepared lasts for a week, exactly as long as the strange labour that trebles the rolume without food. The family remains upon the mother's baek for a fortnight, all told. The Lyeosa carries her young for six or seven months, during which time they are always active and lively, although unfed. What do those of the Seorpion eat, at least after the excoriation that has given them agility and a new life? Does the mother invite them to her meals and reserve the tenderest morsels of her repasts for them? She invites nobody; she reserves nothing.

I serve her a Cricket, chosen among the small game that seems to me best-suited to the delicate nature of her sons. While she gnaws the morsel, without troubling in the least about her surroundings, one of the little ones 
slips down her spine, crawls along her forehead and leans over to see what is happening. He touches the jaws with the tip of his leg; then briskly he retreats, startled. He goes away; and he is well-advised. The abyss engaged in the work of mastication, so far from reserving him a mouthful, might perhaps snap him up and swallow him without giving him a further thought.

A second is hanging on behind the Cricket, of whom the mother is munching the front. He nibbles, he pulls, eager for a bit. His perseverance comes to nothing: the fare is too tough.

I have seen it pretty often: the appetite awakens; the young would gladly accept food, if the mother took the least care to offer them any, especially food adjusted to the weakness of their stomachs ; but she just eats for herself and that is all.

What do you want, O my pretty little Scorpions, who have provided me with such delightful moments? You want to go away, to some distant place, in search of victuals, of the tiniest of tiny beasties. I can see it by your restless roving. You run away from the mother, who, on her side, ceases to know you. You are strong enough ; the hour has come to disperse.

If I knew exactly the infinitesimal game that suited you and if I had sufficient time to procure it for you, I should love to continue your upbringing; but not among the potsherds of the native cage, in the company of your elders. I know their intolerant spirit. The ogres would eat you up, my children. Your own mothers would not spare you. You are strangers to them henceforth. Next year, at the wedding-season, they would eat you, the jealous creatures! You had better go; prudenco demands it. 


\section{THE LIFE AND LOVE OF THE INSECT}

Where could I lodge you and how eould I feed you ? The best thing is to say good-bye, not without a certain regret on my part. One of these days, I will take you and scatter you in your territory, the rock-strewn slope where the sun is so hot. There you will find brothers and sisters who, hardly larger than yourselves, are already leading solitary lives, under their little stones, sometimes no bigger than a thumb-nail. There you will learn the hard struggle for life better than you would with me. 


\section{INDEX}

Axoxia, 145

Anoxia Australis, 150

Anthidium, 100

Anthophora, 132

Aphodians, 35, 79

Apids, 113

Arachnids, 158, 161

Argentine Republic, 101

Bécaru, 196

Butterflies, 113

Calicurgus, 158

$$
\begin{array}{ll}
, & \text { Curra, } 163 \\
, & \text { Ringed, } 157
\end{array}
$$

Capricorn, 100, 181, 194

Carabids, 113, 181

Carcharodon Megalodon, $17 \mathrm{j}$

Caterpillars, Common, 157

Cerambyx, 194

Cerceris, 145

Cetonia, 145

Cockchafer, 51

Coleoptera, 49, 180

Copris, Spanish, 64

Crayfish, 225

Cricket, 100

" Italian, 100

Curculionids, 183, 187

Dectus, 100

Dermestes, 114

Diptera, 90, 179, 180, 201
Dufour, Léon, 248

Dung-beetles, 3, 29, 42, passim

Dynastes Hercules, 90

Dytiscus, 181

Epeira, Banded, 163

, Fasciata, 164

, Silky, 163

Flies, 114

Geotrupes, 28, 84, 117

, Hypocrita, 117

, Mutator, 117

,. Stercorarius, 117

Gnat, 218

Sylvaticus, 117

Grasshoper, Green, 100

Gyrinus, 181

Halictus Zebrus, 200, 214

Horapollo, 52

Huber, 132

Hydrophilus, 181

Hymenoptera, 1, 2, 103, 143, 157. 187

Judulian, Brother, 101

Lamias, 176

Latreille, 5:

Leaf-cutter, 214

Lithodomi, 176 
Lizard, 182

lycosa, 254

,, Narbonnensis, 157

Maistre, Xavier de, 99

Megachile, 100, 214

Minotaurus Typhœus, 91

Mosquito, 181

Moth, Great Peacock, 131

Mulsant, 53

Muscidæ, 218

Necrophores, 103,114

Notidani, 176

Onitis Olivieri, 102

Onthophagus, 80

$\begin{array}{ll}, & \text { Ovatus, } 103 \\ , & \text { Taurus, 80, 81, 88 } \\ \text {, } & \text { Vacca, 91 }\end{array}$

Oryctes, 145

Oxyrhin:e, 176

Pasteur, 243

Pentamera, 49

Petricolæ, 176

Phanæus Milo, 101

Pholaidids, 176

Pliny, 172

Pompilus, 157
Poplar Weevil, 184

Praying Mantis, 100

Rhynchites, 185, 189, 190, 191

Rhynchophora, 180

Rousseau, Jean-Jacques, 99

Sacred Beetle, 5, 18, 23, 29, 37, $41,44,49,50,52,57$

Saint-Pierre, Bernardin de, 99

Saurians, 182

Scarab, 7, 28, 31, 37, 48, 49, 52, 57

," Pharaonic, 54

Scolia, Hemorrhoidal, 143

,, Hortorum, 143

, Interrupted, 150

, Two-banded, 145

Scorpion, Black, 223, 224

, Common, 248

,, Languedocian, 224, 243

Sea-urchins. 176

Silphids, 114

Sisyphus, 84

Squali, 179

Squalidæ, 176

Tarantula, 157, 158

Vine Wecvil, 195

Wecvils, 90, 180, 181 


\section{OTHER NATURE-STUDY BOOKS}

By the Rev. CHARLES A. HALL, F.R.M.S.

\section{THE OPEN BOOK OF NATURE} A BOOK OF NATURE-STUDY FOR YOUNG PEOPLE

Containing $x 6$ full-page Illustrations in Colour, also 114 Reproductions in Black and White from Photographs, as well as numerous Illustrations in the text

\section{Large crown 8vo., bound in cloth}

(By post, 3/ro)

PRICE 36 NET

(By post, 3/ro)

\section{SOME PRESS OPINIONS}

"This pleasantly written book is well fitted to arouse in young people an interest in the study of Nature, while many of older growth will probably find in its pages much that is not unprufitalle reading. .... The chief difference between this bouk and most others on Nature-study is the prominence which it gives to geological subjects. . . . Copiously illustrated." - A thencum.

"Mr. Hall's agreeable, interesting, and instructive volume. . . It should attract not only young people, hut anyone looking for an easy introduction to Nature-study." - Scotsman.

"Comprehensive though it is, it has been planned on clear and simple lines. The terms used are, to begin with, non-scientific, though leading by natural, simple process to the proper scientific words. . . The author writes in a free, bright, and fascinating style; the book is equally fitted for use by teachers, or for study by the young people themselves." Aberdeen Free Press.

"An ideal natural history book. . . Ought to be in every schnol library in the three kingdoms.... No one can read it without feeling the lure of Nature-study."-Review of Keviews.

"Mr. Hall's excellent volume introduces readers to practically every branch of Naturestudy. . . . His descriptions are invariably clear, and the various subjects raised are well managed. . . . The volume is good value in every way."-Bopkman.

"The book is primarily intended for young folks, but it is of equal value to adults, and it is of fascinating interest to people of all ages. . . . A very acceptable work." - Western Mail.

"This fascinating volume." Dundee Advertiser.

\section{HOW TO USE THE MICROSCOPE}

Containing 20 full-page Illustrations from Photo-micrographs, and many Line Drawings in the text.

\section{Large crown 8 vo., bound in cloth}

(By post, $\mathbf{I} / 9$ )

\section{PRICE 1/6 NET}

(By post, I/9)

\section{SOME PRESS OPINIONS}

"There are many cheap bnoks on the nicroscope hefore the public, but we do not know a better than the one now under consideration." - Scottish Naturaist.

"It is, however, the work of an expert, and its simplicity and clearness are the result of a thorough mastery of the subject."-Scottish Field.

"Elaborate explanations are carefully avoided, but the reader who patiently works through the several chapters will have an accurate and scientific knowledge of microscopic possibilities."-Pall Mall Gazette.

"The text contains a wealth of useful advice and instruction. . . We beartily recommend the book."-Entomologist. 


\section{Ey M. D. HAVILAND \\ WILD LIFE ON THE WING}

Containing 8 full-page Illustrations and 50 Smaller Drawings in the Text by PAtTen Wilson

Large square crown 8 vo, cloth, gilt top

(By fost, 5/4)

PRICE 5/= NET

(By fost, 5/4)

These stories of bird life by field, wood, and moor will be read with much zest by all nature-lovers They are brightly written and are the outcome of close observation and much practical knowledge of natural history. One learns not only the secrets of bird-life, but incidentally much about the animals that prey on it. We sympathize with the water-hen hatching out its eggs on a subsiding pool with a vixen waiting to reach her; we are relieved when the peregrine falcon escapes from its human captor; and we read with interest of the last heron of Ballongarry and of all the superstition it aroused in the mind of the old Irish keeper.

Besides the adventures of the water-hen, the falcon, and the heron, there are equally stirring stories of the crow, the woodcock, the redwing, and the pheasant.

\section{SOME PRESS IPINIONS}

"Stories of bird-life, showing much close observation and practical knowledge, as well as a bright and pleasant fancy."-Ladies' Field.

"Its feathered heroes and lieroines are denizens of our own country, and their lives are depicted with the intimacy born of close observation."-Truth.

"The author attfully combines instruction with adventure stories by land, air, and sea." Westminster Gazette.

"A very charming little series of nature stories. Each story consists of the narrative of some particular bird, whose life history, with its joys and sorrows, its dangers ana its lucky escapes, is set forth as faithfully as man can tell it."- Sporting and Dramatic Ncrus.

"Under the guidance of Mr. Haviland, the reader discovers a whole world of living, struggling creatures, and is led to manifest in them a sympathetic interest never felt before." - Aberdeen Daily Journal.

\section{By FRANK FINN, B.A., F.Z.A. TALKS ABOUT BIRDS}

Containing 36 Illustrations, 16 of which are full-page in Co'our

Small square demy 8 vo., cloth, gilt top PRICE 6/.

SOME PRESS OPINIONS

"It is written in a most interesing style, and is sure to captivate intelligent boys and girls.' - Western Morning News.

"Of exceptional interest and worth, as being on quite unusual lines."-Aberdeen Free Press.

"The author writes for young people a book that will interest them and prove a fascinating introduction to the study of ornithology."-Freman's Joumal.

PUBLISHED BY ADAM AND CHARLES BLACK, 4, 5 AND 6 SOHO SQUARE, LONDON, W. 


\title{
By C. VON WYSS
}

\section{GARDENS IN THEIR SEASONS}

\author{
Containing 58 Illustrations, 32 of which are in Colour
}

Crown 4to., canvas boards, with Picture in Colour on the cover

\section{PRICE 1/6}

\section{SOME. PRESS OPINIONS}

"The little folk who are tempted from the gay pictures to the attractive letterpress which describes them, will meet here one of those born gardeners of the seeds of knowledge, who become as children themselves to open out to the little ones a glimpse of the poetry of earth."-Athenaum.

"A most attractive volume, which can bardly fail to prove very popular with the young readers for whom it is intended."-Bookseller.

"It deals interestingly with life of the garden, the life of the birds and insects as well as of the plants and flowers. As a help to Nature-study the book ought to be very useful, and as a gift-book for either girl or boy it would certainly be found suitable."-Woman Teacher.

\section{BEASTS AND BIRDS}

\section{Containing 55 Illustrations, $3 \mathrm{I}$ of which are in Colour}

Crown 4to., canvas boards, with Picture in Colour on the cover PRICE $1 / 6$

\section{SOME PRESS OPINIONS}

"This is described as a Nature Book for boys and girls, and would make a charming and weicome gift for children who are just old enough to learn about, and be interested in animals. A short account of animals and their haunts and customs is given in simple straightforward language, and the profuse illustrations, both plain and coloured, with which the book is furnished, help to make the subject additionally clear and attractive." -Sunday Times.

"Those children who are fond of animals could hardly receive a more pleasing gift."Birmingham Gazette.

"As entertaining as it is instructive, and delightfully illustrated in colours and black and white."-Manchester Courier.

"In simple and yet glowing words the author introduces us to the 'Beasts and Birds,' and the glamour of the pictures is sustained as we read about them."-School Nature-Study.

PUBLISHED BY ADAM AND CHARLES BLACK, 4, 5 AND 6, SOHO SQUARE, LONDON, W. 


\section{"PEEPS AT NATURE"}

Edited by the Rev. CHARLES A. HALL, F.R.M.S.

Each containing 16 full-page Illustrations, 8 of which are in Colour. Large crown 8vo., cloth, with Picture in Colour on the cover

(Postfree, I/9) PRICE 1/6 NET PER VOLUME (Post free, I/9)

$$
\text { LIST OF VOLUMES }
$$

WILD FLOWERS AND THEIR WONDERFUL WAYS

By the Rev. Charles A. Hall, F.R.M.S.

BIRD LIFE OF THE SEASONS

By W. Percival Westell, F.L.S.

BRITISH LAND MAMMALS

By A. Nicol Simpson, F.Z.S.

BRITISH FERNS, CLUB-MOSSES, AND HORSETAILS

By Daniel Ferguson, M.A.

BRITISH BUTTERFLIES

By A. M. Stewart.

NATURAL HISTORY OF THE GARDEN

By W. Percival. Westell, F.L.S.

ROMANCE OF THE ROCKS

By the Rev. Charles A. Hall, F.R.M.S.

THE NATURALIST AT THE SEASHORE

By Richard Elmhirst, F.L.S., Superintendent of the Millport

Marine Biological Station.

BRITISH REPTILES AND AMPHIBIANS

By A. Nicol Simpson, F.Z.S.

POND LIFE

By the Rev. Charles A. Hali, F.R.M.S.

COMMON BRITISH MOTHS

By A. M. STEWART.

COMMON BRITISH BEETLES

By the Rev. Charles A, Hall, F.R.Mi.S.

PEEPS AT THE HEAVENS

By the Rev. James Baikie, F.R.A.S. Containing i6 Full-page Illustrations ( 8 in Colour). Cloth, Picture Cover. Price 16 net. 


\section{LIFE STORIES OF ANIMALS}

Each volume containing 8 full-page Illustrations in Colour, with Coloured Picture on cover. Large crown 8vo., cloth

\section{PRICE 3/6 EACH}

\section{Volumes iN THE SERIES}

THE BLACK BEAR

By H. Perry-Robinson

THE CAT

By Violet Hunt

THE DOG

By G. E. Mitton

THE FOWL

By J. W. Hurst

THE FOX

By J. C. Tregarthen
THE LION

By Agnes Herbert

THE RAT

By G. M. A. Hewett

THE SQUIRREL

By T. C. Bridges

THE TIGER

By Lt.Col. A. F. MocklerFerryman

\section{NOTE}

THE keen interest of the young people of to-day in Nature, particularly as exemplified in animals and their habits, is a very encouraging and noticeable sign of improved upbringing. Children of nearly all ages are thrilled with the life stories of animals told by themselves, such as those in this scries of volumes. To read of the squirrel from the squirrel's point of view makes that dainiy little animal's life and habits of intense interest the next time a woodland walk gives young or old a chance of seeing a little streak of brown fur slipping along a branch. Although animal autobiographies of this character are written mainly for the young, and are eagerly read by boys and girls who are just beyond fairy stories, there is no doubt that older folk get interested directly they have glanced at a page or two. This means that the animal's point of view, set down by a writer who really knows his subject, is always fresh and interesting. It was Mr. Kipling who told us that the jungle-folk call the twolegged creatures who carry guns "the man pack," and it was Mr. Grant Allen who stirred one to sympathize with the maternal earwig; and this series of nine books, each illustrated with clever pictures in colour by artists of repute, will make the world more interesting to many young folk. 


\section{By CONSTANCE INNES POCOCK \\ HIGHWAYS AND BYWAYS OF THE ZOOLOGICAL GARDENS}

Containing 32 full-page Illustrations from Photographs and a Frontispiece in Colour

Small square demy 8 vo., cloth, gilt top

(By post, 5 ;)

PRICE 5/= NET

(By post, 5/4)

\section{SOME PRESS OPINIONS}

"This handsoms book, with its innumerable illustrations, will be of the greatest interest to any student of animal life. We congratulate the authoress on the pleasing and learned manner in which she discourses on the different animals; their characteristics and habits she has evidently studied minutely." - Britis/ Weekly.

"A book of peculiar charm."-Manchester Guardian.

"As the wife of the Superintendent of the Gardens, the author has had excellent opportunity for observing the captives in Regent's Park, and her notes and descriptions, not only of the more showy animals, but of the more retiring specimens, are remarkably interesting." Truth.

"A valuable and handsome souvenir of a visit to that fascinating place."-Christian II orld.

"The book is full of anecdotes and tit-bits from the Zoo world, and will form a very welcone present to any lover of animals."-Nottingham Guardian.

\section{By AGNES HERBERT,}

Author of "The Lion" in the "Life Stories of Antmals" Series

\section{THE MOOSE}

\section{Containing 8 full-page Illustrations by PATtEN WiLsON}

Small square demy 8 vo., cloth, gilt top

(By post, 5 4)

PRICE 5 - NET

(By post, 5/4)

SOME PRESS OPINIONS

"Written with knowledge and sympathy, and the insight compounded of the two."Eventng Stundard.

"One of the most fascinating of wild animals, the life of the Moose is so little known to the majority of people that this story of his life is of the greatest interest." - Sunday Times.

"In Miss Herbert's book the Moose is drawn so vividly that the reader seems to see him palpitating with life, and follows bis career with interest right to its tragic close." $-D$ undee Advertiser.

"Natural history has seldom been presented in a more fascinating manner than that chosen by Miss Herbert, whose book will be read with delight by both old and young." - The Sphere.

"Miss Herbert knows him as he is in his haunts, and she presents him with remarkable clearness and insight. 'The illustrations by Patten Wilson admirably supplement the author's vivid narrative, showing many typical scenes, including the pathetic incident of the death of the Moose cow, the hero's mother."-Nottingham Guardian.

PUBLISHED BY ADAM AND CHARLES BLACK, 4, 5 AND 6 SOHO SQUARE, LONDON, W. 



